
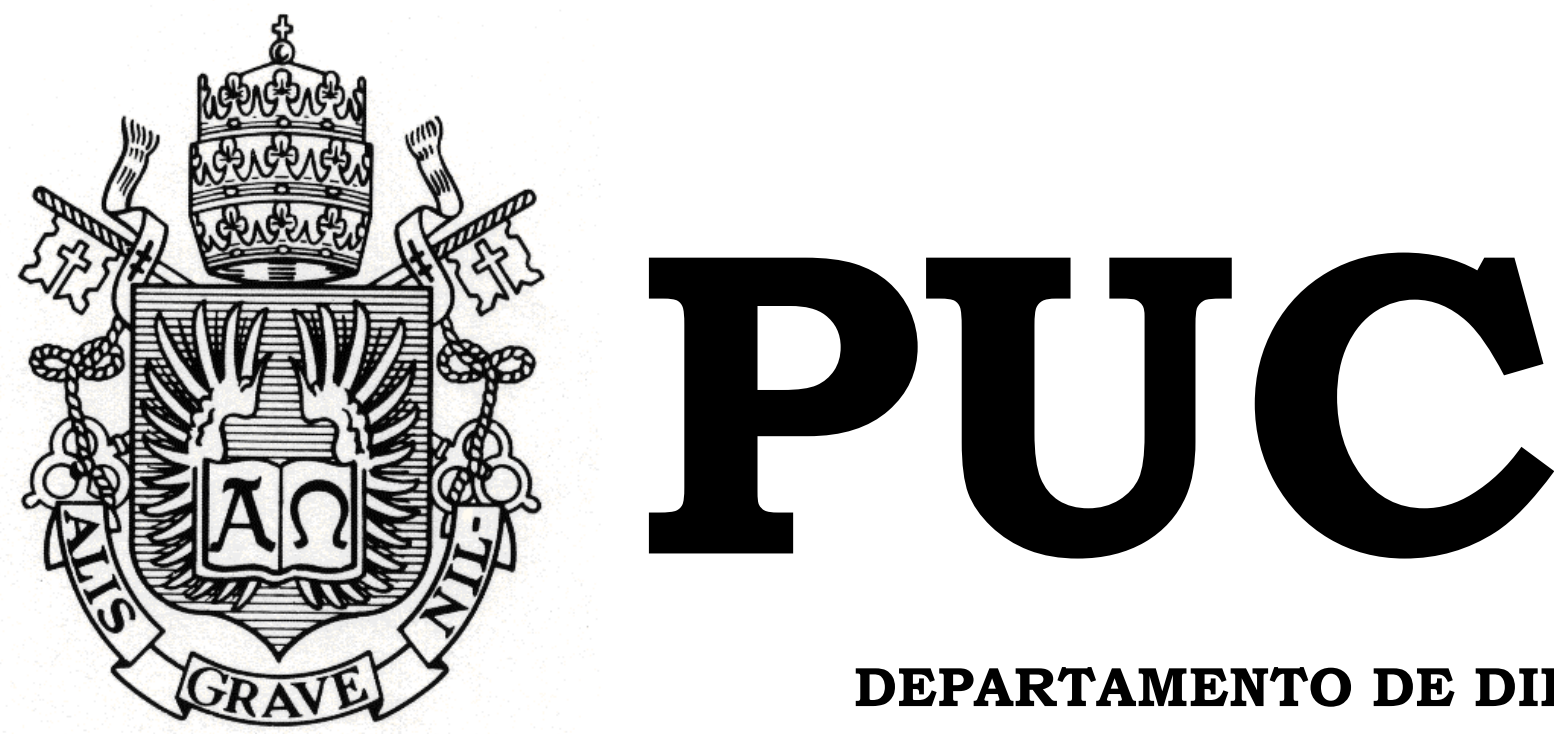

DEPARTAMENTO DE DIREITO

\title{
CAPITAL DE RISCO: CONCEITOS E MECANISMOS DE SAÍDA
}

por

BÁRBARA ELENA GOMES DE AGUIAR

ORIENTADOR: FRANCISCO MÜSSNICH

2017.1

PONTIFÍCIA UNIVERSIDADE CATÓLICA DO RIO DE JANEIRO

RUA MARQUÊS DE SÃO VICENTE, 225 - CEP 22453-900

RIO DE JANEIRO - BRASIL 


\title{
CAPITAL DE RISCO: CONCEITOS E MECANISMOS DE SAÍDA
}

\author{
por \\ BÁRBARA ELENA GOMES DE AGUIAR
}

Monografia apresentada ao

Departamento de Direito da

Pontifícia Universidade Católica do Rio de Janeiro (PUC-Rio) para a obtenção do Título de Bacharel em Direito.

Orientador: Francisco Müssnich 


\section{AGRADECIMENTOS}

Aos meus pais, Chris e Pero, por me ensinarem que não há limites para os sonhos quando se tem força de vontade e amor pelo percurso a ser percorrido. Agradeço por me mostrarem que o conhecimento é o bem mais valioso que podemos conquistar. Mãe, obrigada por me mostrar o lado leve da vida. Obrigada por me ensinar o valor da espiritualidade. Obrigada por manifestar todos os dias o seu amor incondicional. Pai, obrigada por me ensinar o valor de uma boa leitura. Obrigada por me apoiar em todos os meus desafios, e por ser o meu melhor amigo.

Aos meus tios, Luis e Roberta, por terem me mostrado o valor da palavra família, me apoiando na minha maior conquista. Tio, obrigada por ser, ao lado do meu pai, a minha referência de amor à profissão. O exemplo de vocês realmente me inspira diariamente. Obrigada pela parceria e por todo carinho e atenção que você vem dedicado a mim.

Ao meu irmão, João, por ser o meu maior companheiro, por estar ao meu lado em todos os meus desafios, e por encarar de mãos dadas comigo todas as mudanças, choros e risadas. Sinceramente, obrigada por uma vida inteira juntos.

Agradeço ainda aos meus colegas de trabalho, que são verdadeiros professores para mim: Rapha, Anna, Pedro, Lari, Marcelo, Fábio, Mari, Thaís, Diana, Alexia - obrigada por todo crescimento pessoal e profissional que vocês me proporcionam todos os dias.

Às minhas amigas, irmãs, parceiras de jornada acadêmica. Obrigada por serem meu braço direito nessa caminhada. Esses cinco anos não seriam tão maravilhosos sem vocês.

Por fim, agradeço aos meus amigos de vida, que apesar das minhas ausências principalmente nestes dois últimos anos, sempre me deram todo apoio e energia positiva para eu seguir adiante. 
Para ser grande, sê inteiro: nada Teu exagera ou exclui.

Sê todo em cada coisa. Põe quanto és No mínimo que fazes.

Assim em cada lago a lua toda Brilha, porque alta vive.

Ricardo Reis, 14-2-1933 


\section{RESUMO}

O presente trabalho monográfico tem por escopo a análise da estrutura organizacional das modalidades mais conhecidas do investimento de capital de risco, o Private Equity e o Venture Capital ("PE/VC"). Após uma breve exposição da análise histórica destes segmentos, no Brasil e nos Estados Unidos, são apresentadas as principais características desta indústria - que a tornam inovadora, quando comparada com qualquer outra forma de investimento ou financiamento existente no mercado nacional e internacional. Para fins de diferenciação entre os dois segmentos, são apresentados os diferentes estágios de desenvolvimento dos empreendimentos alvo desta indústria, e em seguida, apresentadas as fases do ciclo de investimento do PE/VC. Por fim, são apresentados os métodos de desinvestimento ou saída do investimento de risco, momento em que há a maximização dos lucros, e consequentemente, momento crucial para todos os agentes envolvidos no investimento. Por fim, são analisados os mecanismos contratuais de saída/liquidez, que têm como objetivo possibilitar que o desinvestimento seja realizado conforme planejado pelo gestor do veículo de investimento no início do ciclo de investimento, e conforme acompanhado durante toda a permanência do veículo de PE/VC na empresa investida.

Palavras-Chave: Capital de Risco - Private Equity - Venture Capital PE/VC - Fundos de Investimento em Participações - Comissão de Valores Mobiliários - Instruções Normativas - Ciclo de Investimento Desinvestimento - Liquidez - Mecanismos de Saída. 


\section{SUMÁRIO}

CAPÍTULO I. O INVESTIMENTO DE CAPITAL DE RISCO ................... 6

1.1. Diferenciação entre as nomenclaturas: Venture Capital e Private

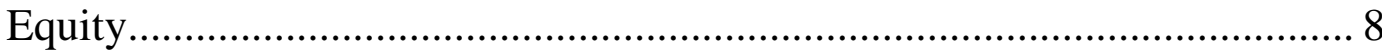

1.2. Trajetória Histórica nos Estados Unidos .............................................. 10

1.3. Trajetória Histórica no Brasil .............................................................. 15

CAPÍTULO 2. CARACTERÍSTICAS DO INVESTIMENTO ................... 25

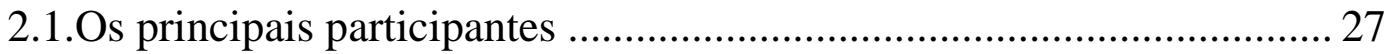

2.2. Característica principal: o alto risco de investimento .......................... 38

CAPÍTULO 3. A LÓGICA DO INVESTIMENTO DE CAPITAL DE

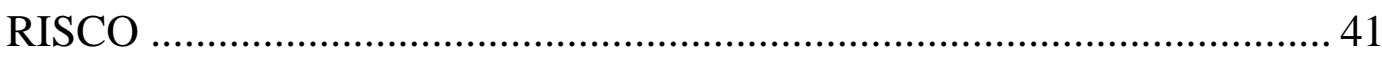

3.1.Os estágios de desenvolvimento dos empreendimentos avo................... 41

3.2. O ciclo de investimento no capital de risco.......................................... 47

CAPÍTULO 4. O DESINVESTIMENTO ……............................................. 52

4.1. Estratégias de Saída do Investimento .................................................... 52

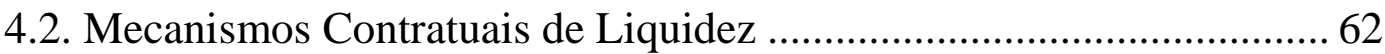

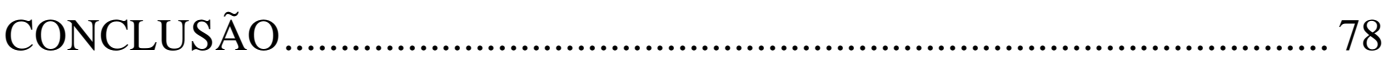

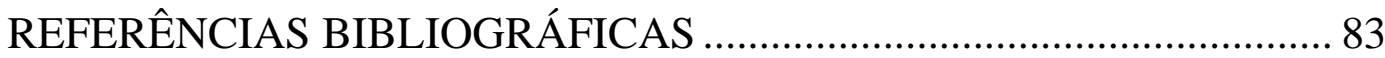




\section{CAPÍTULO 1. O INVESTIMENTO DE CAPITAL DE RISCO}

O emprego do capital de risco como forma de alavancagem de empresas tem pouco mais de 20 anos de idade no Brasil. O Venture Capital e o Private Equity são duas das principais modalidades dos investimentos de capital de risco. Os investimentos são, majoritariamente, realizados em veículos que são frutos de inovação financeira e segmentação crescente no mercado.

Em geral, colocam-se a serviço do empreendedorismo, viabilizando o desenvolvimento de projetos, que, em seus estágios embrionários e/ou de maior risco, talvez não encontrassem outra fonte de capital ${ }^{1}$.

O principal benefício que essa modalidade de investimento trouxe é a disponibilização dos recursos financeiros que viabilizam o negócio de novos empreendedores em diferentes fases de desenvolvimento do seu negócio seja na pesquisa e desenvolvimento de novos produtos e serviços, seja na comercialização de um produto já existente, ou expansão do negócio em uma fase pós-estruturação.

Isto, pois os tradicionais meios de obtenção de financiamentos, as instituições financeiras, tendem a dificultar a obtenção de capital por meio da exigência de garantias e outros requisitos formais, impossibilitando a obtenção do crédito bancário pelos pequenos e novos empreendedores.

Por serem, muitas vezes, a única fonte de capitalização desses negócios, o investimento de Private Equity e Venture Capital têm um papel de desenvolvimento tecnológico e econômico de qualquer país. Os impactos socioeconômicos são, dentre outros, a criação de empresas, geração de

1 ENEI, José Virgílio Lopes. O capital de risco e o Private Equity no Brasil: a nova lógica do investimento. In: ADAMEK, Marcelo Vieira Von (Coord.). Temas de direito societário e empresarial contemporâneos. p. 714. São Paulo: Malheiros, 2011. 
empregos e promoção da inovação ${ }^{2}$. Consequentemente, é comum encontrarmos agências multilaterais e governos, por meio de bancos de desenvolvimento, empresas públicas e autarquias, entre os investidores deste setor.

Além do financiamento e avanço tecnológico, a estrutura de operação deste segmento traz uma contribuição decisiva na implantação, consolidação e expansão de novos ou pequenos empreendimentos, já que os fundos de Private Equity e Venture Capital atuam diretamente, em diferentes graus, na gestão da empresa investida ${ }^{3}$.

Aos olhos do mercado, a empresa escolhida pelo fundo adquire uma espécie de certificação idônea sobre a viabilidade do empreendimento - o que transmite mais confiança aos consumidores, aos fornecedores, aos empregados e toda rede de relacionamentos diretos ou indiretos que a empresa mantém com o restante do mercado4.

Para a sociedade, o sucesso de mais uma empresa resulta nos benefícios trazidos pelo desempenho de sua função social, enquanto fonte geradora de renda, postos de trabalho, tributos e inovações tecnológicas, contribuindo para o progresso econômico do país 5 .

2 RIECHE, Fernando Ceschin; SANTOS, Leonardo Pereira R. dos. Investimentos em pequenas e médias empresas com elevado potencial de crescimento - Critérios de seleção dos capitalistas de risco. Revista do BNDES - Banco Nacional de Desenvolvimento Social e Econômico, vol. 13, n. 26, p. 91 . Disponível em: < www.bndes.gov.br/SiteBNDES/bndes/bndes_pt/Institucional/Publicacoes/Consulta_Expressa/Seto r/Pequenas_e_Medias > Acesso em: 23 abril.2017

3 BERNARDINO, Diogo. Fundos de Venture Capital e Private Equity: breve análise sobre sua evolução, características e importância. Revista de Direito Bancário e Mercado de Capitais, São Paulo, v. 61, p.58, jul./set. 2013. Trimestral.

4 Ibidem. p.59.

5 Ibidem. 


\subsection{Diferenciação entre as nomenclaturas: Venture Capital e Private}

\section{Equity}

Cabe destacar que, embora ao longo deste trabalho, os termos Venture Capital e Private Equity sejam empregados como sinônimos, em sentido estrito, eles costumam ser diferenciados quanto às diversas etapas dos empreendimentos alvo dos recursos oferecidos pelos fundos de capital de risco.

Por um lado, a expressão Venture Capital está associada aos investimentos realizados em empreendimentos que se encontram em estágios iniciais, ainda não constituídos ou recentemente fundados (anteriores ao estágio do desenvolvimento). Por isso, o investimento é normalmente empregado em pesquisa e desenvolvimento da ideia original, a par de que o negócio possa ser viabilizado perante o mercado ${ }^{6}$.

Por outro lado, a expressão Private Equity é empregada para caracterizar investimentos em empresas já existentes, normalmente já consolidadas no mercado, em fase de expansão, ou ainda, mesmo aquelas que enfrentem dificuldades financeiras (recuperação judicial ou extrajudicial) 7 . Muitas vezes, esses empreendimentos necessitam não apenas do capital financeiro aportado pelo fundo de capital de risco, como também, do capital informacional dos gestores do fundo para, por exemplo, auxiliar na reestruturação da governança coorporativa do empreendimento.

Consequentemente, a diferenciação dos termos também está presente no emprego desses recursos na empresa investida. O montante recebido pelos empreendedores no segmento de Venture Capital é usualmente utilizado para

6 Ibidem.

7 BERNARDINO, Diogo. Fundos de Venture Capital e Private Equity: breve análise sobre sua evolução, características e importância. Revista de Direito Bancário e Mercado de Capitais, São Paulo, v. 61, p.59, jul./set. 2013. Trimestral. 
a pesquisa e o desenvolvimento da ideia original, para que o negócio possa ser viabilizado perante o mercado, enquanto que o investimento direcionado às empresas no segmento de Private Equity é utilizado para a expansão dos negócios de empresas já consolidadas, ou para salva-las de dificuldades financeiras.

Private Equity fornece capital para empresas não cotadas em bolsa de valores. Private Equity pode ser usado para desenvolver novos produtos e tecnologias, para ampliar capital de giro, para fazer aquisições, ou para equilibrar caixa de uma empresa (...). O Venture Capital é, estritamente falando, um subconjunto de Private Equity e refere-se a investimentos feitos para o lançamento, desenvolvimento inicial, ou a expansão de um negócio. (trad. livre $)^{8}$

A partir da classificação apresentada, percebe-se que a expressão Venture Capital é utilizada para investimentos entre as fases de seed e start up, enquanto que a expressão Private Equity se refere aos estágios posteriores ${ }^{9}$. É justamente essa diferença de foco, portanto, que caracteriza o Private Equity e o Venture Capital como setores distintos dentro do conceito de investimento de capital de risco, embora existam áreas de intersecção ${ }^{10}$. Para uma melhor fluência do raciocínio, iremos emprega-las como sinônimas algumas vezes durante este trabalho - através do uso de expressões como "PE/VC", ou ainda, "veículos de Private Equity e Venture Capital".

\footnotetext{
8 WEIDIG, Tom; MATHONET, Pierre-Yves. The Risk Profiles of Private Equity - Private Equity is a risky asset, but private equity investments are not necessarily so. Disponível em: < http://papers.ssrn.com/sol3/papers.cfm?abstract_id=495482 > Acesso em 01. Maio. 2017. Trad. livre: Private Equity provides equity to enterprises not quoted on a stock market. "Private Equity can be used to develop new products and technologies, to expand working capital, to make acquisitions, or to strengthen a company's balance sheet (...). Venture Capital is, strictly speaking, a subset of Private Equity and refers to equity investments made for the launch, early development, or expansion of a business."

9 ANDERS, Eduardo Caminati. Private Equity e o controle preventivo exercido pelo Cade. In: ARAGÃO, Leandro Santos; CASTRO, Rodrigo R. Monteiro de. Direito societário: desafios atuais. São Paulo: Quatier Latin: 2009. P. 47.

10 CARVALHO, Antônio Gledson de Carvalho; RIBEIRO, Leonardo de Lima; FURTADO, Cláudio Vilar. A Indústria de Private Equity e Venture Capital: Primeiro Censo Brasileiro, cit., p. 31.
} 


\subsection{Trajetória Histórica nos Estados Unidos}

A concepção moderna do capital de risco - ou seja, que envolve a gestão profissional de recursos de terceiros através de entidades que são utilizadas como veículos para a realização de investimentos em empresas emergentes encontra a sua origem nos Estados Unidos, na década de 40, quando George Doriot cria a American Research and Development Corporation Act (ARD). O seu objetivo era prover capital a empreendimentos inovadores que não eram capazes de obter financiamentos tradicionais no sistema financeiro de então, por falta de garantias reais tradicionalmente aceitas ${ }^{11}$.

Embora o esforço empregado à criação da American Research and Development pelo ex-reitor da Harvard Business School, em conjunto com outros membros da Massachussets Institute of Tecnology (MIT) e outros empreendedores locais, o sucesso dos investimentos em capital de risco não foi imediato. Cinco anos após a criação da empresa, seus primeiros investidores haviam perdido cerca de $24 \%$ do montante aplicado ${ }^{12}$.

Em virtude do insucesso preliminar, os gestores de investimentos desta natureza entenderam que, para o amadurecimento da indústria de capital de risco, seria necessário respeitar duas premissas básicas: (i) a perspectiva de longo prazo (superiores a 10 anos) para retorno da aplicação; e (ii) a necessidade de acompanhamento próximo e contínuo dos empreendimentos que recebiam aportes financeiros, inclusive com a participação efetiva das firmas de Private Equity nas decisões cotidianas das empresas investidas ${ }^{13}$.

\footnotetext{
11 ENEI, José Virgílio Lopes. O capital de risco e o private equity no Brasil: a nova lógica do investimento. In: ADAMEK, Marcelo Vieira Von (Coord.). Temas de direito societário e empresarial contemporâneos. p. 715. São Paulo: Malheiros, 2011.

12 SÁ, Thomas Tosta de. Empreendedorismo e Venture Capital: perspectivas para o Brasil Disponível em: <http://www.redetec.org.br/publique/media/thomas.pdf>. Acesso em: 22 abril. 2017.

13 BERNARDINO, Diogo. Fundos de Venture Capital e Private Equity: breve análise sobre sua evolução, características e importância. Revista de Direito Bancário e Mercado de Capitais, São Paulo, v. 61, p.46, jul./set. 2013. Trimestral.
} 
No final da década de 1950, observou-se um crescimento acentuado de pequenas empresas americanas, após a criação do Small Business Administration, em 1953, que tinha como finalidade o aconselhamento e desenvolvimento de empreendimentos de pequeno porte através da concessão de empréstimos diretos, ou oferecimento de garantias aos bancos viabilizando, assim, a contratação de empréstimos pelas empresas $\operatorname{assistidas~}^{14}$.

$\mathrm{Na}$ sequência, o Congresso Americano editou o The Investment Company Act of 1958, estabelecendo o programa Small Business Investment Company (SBIC), que permitiu que firmas que se destinavam à realização de aportes financeiros em empresas em estágio inicial (mas com alto potencial de crescimento e de rentabilidade), também pegassem empréstimos garantidos pelo Governo Americano. ${ }^{15}$ Assim, o governo estimulou os investidores profissionais, facilitando ainda mais o fluxo de capital de longo prazo, já que a SBA não oferecia empréstimos diretos ${ }^{16}$. Essa iniciativa possibilitou o treinamento e a formação de uma geração de profissionais de Venture Capital ${ }^{17}$.

O objetivo do governo era garantir a contínua inovação e a rápida expansão da base tecnológica norte-americana. Assim, outros diplomas legais contribuíram decisivamente para a consolidação do capital de risco, sendo o mais significante a criação das Limted Partnerships, forma societária que passou a ser adotada como padrão da indústria de Venture Capital:

Um marco importante para a indústria de VC [Venture Capital] veio na década de 1960 com o desenvolvimento de parcerias limitadas para investimentos de VC. Neste arranjo, os investidores fazem o aporte de capital e pagam algum percentual a título

\footnotetext{
14 Ibidem.

15 Ibidem.

16 ESTADOS UNIDOS. U.S. SMALL BUSINESS ADMINISTRATION. (Org.). Home page. 2017. Disponível em: <https://www.sba.gov/about-sba> Acesso em: 22 abril 2017.

17 ENEI, José Virgílio Lopes. O capital de risco e o private equity no Brasil: a nova lógica do investimento. In: ADAMEK, Marcelo Vieira Von (Coord.). Temas de direito societário e empresarial contemporâneos. p. 715. São Paulo: Malheiros, 2011.
} 
de taxas de gestão do fundo. O restante do capital é investido pelo fundo administrador em empresas. $O$ fundo realiza o desinvestimento dos empreendimentos de sucesso por meio da venda da empresa investida ou através da abertura de seu capital. O arranjo mais comum é a divisão dos ganhos na proporção de 80-20: após o retorno do montante inicial aos investidores, o fundo permanece com 20 por cento de tudo. Esta forma de divisão dos lucros - conhecida como ganho conquistado/agregado - é o incentivo que faz os investimentos em Private Equity serem tão atraentes para investidores profissionais (trad. livre) ${ }^{18}$.

Em 1978, o Revenue Act estabeleceu alíquotas mais baixas de imposto de renda para o ganho de capital. No ano seguinte, foi editado o Employee Retirement Income Act (Prudent Man Rule) que causou o relaxamento de alguns limites e regras da indústria de capital de risco, possibilitando participação dos fundos de pensão em tais investimentos ${ }^{19}$, uma vez que, além de promover maior transparência na gestão dos fundos de aposentadoria privados, permitiu-lhes investir 5\% de seus ativos na aquisição de capital de risco - dentre eles Venture Capital -, atuando favoravelmente na consolidação da indústria ${ }^{20}$.

Além do objetivo governamental em criar um ambiente institucional adequado e o capital intelectual efetivo ao empreendedorismo, a existência de um mercado de capitais com grande volume de negócios foi circunstância primordial para encorajar aportes de longo prazo em títulos de baixa liquidez, como é o caso dos papéis relacionados à indústria de capital de risco - dado que, por conta da alta liquidez dos títulos que eram lançados no mercado de

18 “An important milestone for VC industry came in the 1960s with the development of the limited partnerships for $\mathrm{VC}$ investments. In this arrangement, limited partners put up the capital, with a few percentage points of this capital paid every year for management feeds of the fund. The general partner in private companies then invests the remaining capital. Successful investments are exited, either through a private sale or a public offering, before the ten-year life of the partnership expires. The most common profit-sharing arrangement is an 80-20 split: after returning all the original investment to the limited partner, the general partner keeps 20 percent of everything else. This profit sharing, known as carried interest, is the incentive that makes private equity investing so enticing for investment professionals." Cf. METRICK, Andrew; YASUDA,Ayako. Venture Capital \& The Finance of Inovation. Hoboken: John Wiley \& Sons, Inc, 2010, p. 11.

19 ENEI, José Virgílio Lopes. O capital de risco e o private equity no Brasil: a nova lógica do investimento. In: ADAMEK, Marcelo Vieira Von (Coord.). Temas de direito societário $e$ empresarial contemporâneos. p. 715. São Paulo: Malheiros, 2011.

20 REBELO, Nikolai Sosa. Os Investimentos e a Captação de Recursos por Contratos de Private Equity e Venture Capital. Síntese Direito Empresarial, São Paulo, v. 29, p. 205, nov./dez. 2012. Bimestral. 
capitais americano, os investidores tinham grande expectativa em sair do investimento por meio de IPO (Initial Public Offering), o que aumentava a perspectiva de altos rendimentos para o investidor ${ }^{21}$.

As oscilações no volume de recursos empregados pelas firmas de Venture Capital dos Estados Unidos podem ser observadas nos gráficos inseridos abaixo, elaborados com base nos dados fornecidos pela Associação Nacional de Venture Capital norte-americana (National Venture Capital Association - NVCA)22 em 2016.

\section{Gráfico 1. - Capital comprometido: Fundos de Risco nos EUA (1995- 2015)}

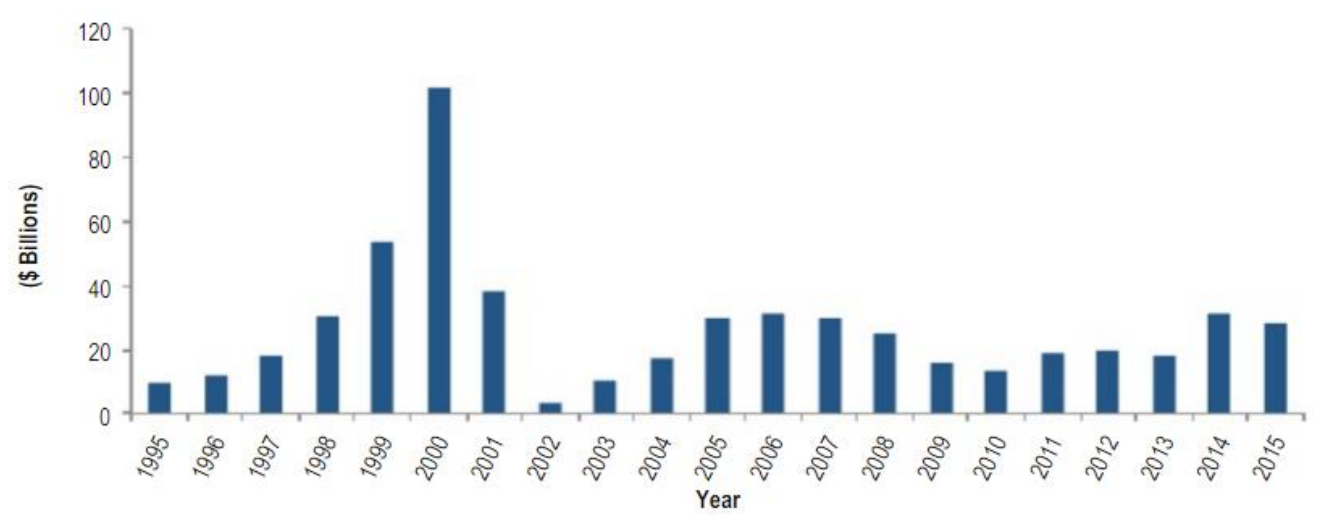

Fonte: NVCA - Yearbook - 2016

O primeiro gráfico apresenta a evolução do capital comprometido entre 1985 e 2015. Destaca-se o crescimento astronômico dos investimentos nos anos 2000, em grande medida, decorrente dos avanços tecnológicos na Internet, ultrapassando 100 bilhões de Dólares, período e fenômeno estes conhecidos como "boom period" ou "bolha da internet". Com o estouro da bolha da Internet, os investimentos reduziram-se drasticamente, mantendo a

21 BERNARDINO, Diogo. Fundos de Venture Capital e Private Equity: breve análise sobre sua evolução, características e importância. Revista de Direito Bancário e Mercado de Capitais, São Paulo, v. 61, p.47, jul./set. 2013. Trimestral.

$22 \mathrm{O}$ site da National Venture Capital Association (NVCA) disponibiliza uma série de estudos, dados e artigos científicos sobre a indústria de Venture Capital Americano. Disponível em: <http://nvca.org/> Acesso em: 22 abril 2017. 
média de 20 bilhões de Dólares no período de 2002 a 2005 (postboom period $)^{23}$.

No período de 2005 até 2008 sobreveio nova recuperação, e finalmente em 2008 e 2009 nova retração, em decorrência da crise global. Apesar das oscilações, a tendência do seguimento se mostrou ser de crescimento sustentado no longo prazo ${ }^{24}$.

\section{Gráfico 2. - Capital administrado pelos Fundos de Capital de Risco nos}

\section{EUA (1995 - 2015)}

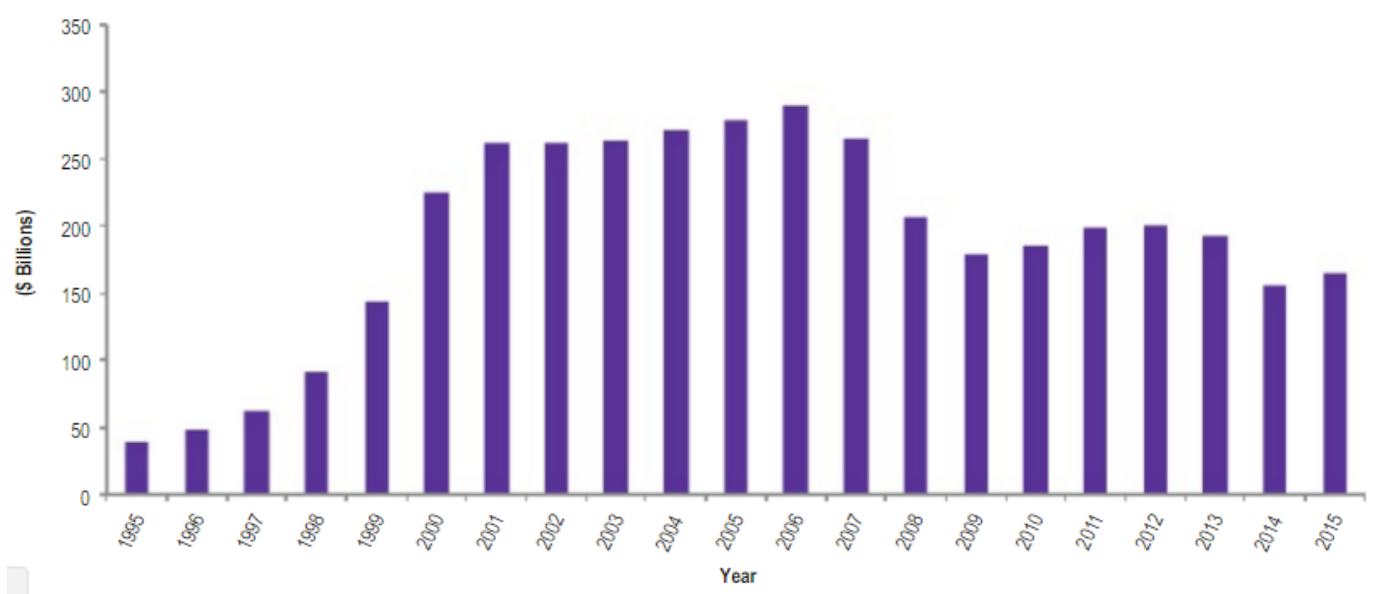

Fonte: NVCA - Yearbook - 2016

Por outro lado, conforme refletido no segundo gráfico, embora em 2000, a "bolha da internet" tenha causado grandes prejuízos e reduzido o capital injetado no mercado, não houve redução do volume de capital administrado pelos fundos - demonstrando confiança na indústria da Venture Capital.

23 METRICK, Andrew. Venture Capital and the Finance of Innovation, Estados Unidos da América, Wiley, 2007, p. 12 e 13 ("Prefácio" e primeiro capítulo disponíveis em < http://ssrn.com/abstract=929145_>. Acesso em 22/04/2017).

24 ENEI, José Virgílio Lopes. O Capital de Risco e o Private Equity no Brasil. Livro Temas de Direito Societário e Empresarial Contemporâneos - Liber Amicorum - Prof. Dr. Erasmo Valladão Azevedo e Novaes França, coordenação Marcelo Vieira von Adamek. p. 716. Malheiros Editores. 
Cumpre destacar que os investimentos de Private Equity e Venture Capital foram os responsáveis pelo crescimento de empresas como Intel, Fedex, Apple, Dasa, Totvs, Alellyx, Genentech, Facebook, Microsoft, Starbucks, entre outras, que rapidamente, tornaram-se grandes corporações ${ }^{25}$.

\subsection{Trajetória Histórica no Brasil}

No Brasil, o primeiro fundo de investimento surgiu no início do governo de Juscelino Kubitschek, marcado por uma euforia desenvolvimentista. O fundo CRESCINCO foi criado em 1957, e pertencia à International Basic Economy Corporation ${ }^{26}$, uma empresa que fazia parte dos empreendimentos da família Rockefeller. Ainda que não fosse considerado um fundo de Private Equity ou Venture Capital, ele foi o primeiro a ser constituído na forma de condomínio - mesma forma jurídica adotada pelos fundos de investimentos em participação na norma vigente ${ }^{27}$.

Posteriormente, em 1974, o BNDES estabeleceu três companhias subsidiárias com objetivo de capitalizar empresas brasileiras com potencial de crescimento elevado: Embramec, Fibase e Ibrasa - que, em fase posterior, fundiram-se para criar a BNDES Participações S.A. ${ }^{28}$

Segundo os dados do Centro de Estudos em Private Equity (GVcepe) da Fundação Getúlio Vargas (FGV), a Brasilpar, fundada em 1976 - mesmo ano da promulgação da Lei das Sociedades Anônimas (Lei 6.404/76) e da

\footnotetext{
25 Ibidem, p. 49.

26 THE INTERNATIONAL BASIC ECONOMY CORPORATION (Org.). Historical Notes. 2006. Disponível em: <http://www.capital-flow-analysis.com/investmenttutorial/case_1w.html> Acesso em: 23 abril. 2017

27 REBELO, Nikolai Sosa. Os Investimentos e a Captação de Recursos por Contratos de Private Equity e Venture Capital. Síntese Direito Empresarial, São Paulo, v. 29, p. 206, nov./dez. 2012. Bimestral.

28 BERNARDINO, Diogo. Fundos de Venture Capital e Private Equity: breve análise sobre sua evolução, características e importância. Revista de Direito Bancário e Mercado de Capitais, São Paulo, v. 61, p.50, jul./set. 2013. Trimestral.
} 
criação da Comissão de Valores Mobiliários (CVM) - foi a primeira companhia de Venture Capital do Brasil. O seu objetivo era estimular o capital empreendedor no país ${ }^{29}$.

Ainda no final da década de 80, Jorge Paulo Lemann, Carlos Alberto Sicupira e Marcel Hermann Telles, sócios do Banco Garantia, adquiriam o controle das Lojas Americanas e da cervejaria Brahma ${ }^{30}$.

Em 1993, surgiu a GP Investments, comandada pelo trio de financistas, e considerada a primeira sociedade privada com foco no mercado de capital de risco, com aportes de aproximadamente US\$500 milhões em empresas como a Shoptime, Globo Cabo e a Artex ${ }^{31}$.

No mesmo ano, a CVM editou a IN 209/94², que regulou a criação dos Fundos de Mútuos de Investimentos em Empresas Emergentes (FMIEEs), cujo diferencial era a aplicação de recursos em empreendimentos novos ou em fase de consolidação com perspectiva de grande rendimento no longo prazo $^{33}$.

\footnotetext{
29 FUNDAÇÃO GETÚLIO VARGAS. GVcepe. Centro de Estudos em Private Equity. Introdução ao Private Euqity e Venture Capital Paraty Empreendedores. Disponível em: < http://www5.fgv.br/fgvonline/owc/OWCPEVCEAD/index2.htmcpf=94700648104\&prod_cd=OC WPEVCECAD_00_O1/2010_1>. Acesso em: 12 dez. 2016. 30 AGÊNCIA BRASILEIRA DE DESENVOLVIMENTO INDUSTRIAL. A indústria de Private Equity e Venture Capital: $2^{\circ}$ Censo Brasileiro. Brasília, 2011. p. 61. Disponível em: < http://www.abdi.com.br/Estudo/Private_Equity_e_Venture_Censo.pdf $>$. Acesso em: 23 abril. 2017. 31 Ibidem.

32 A IN 209/94 foi revogada pela IN 578/16 - que dispõe sobre a constituição, o funcionamento e a administração dos Fundos de Investimento em Participações. Com isso, os FMIEEs, já existentes, poderão continuar operando nos seus moldes atuais, sem a necessidade de adaptação, sendo vedada a prorrogação de seu prazo de duração, exceto se houver o atendimento à nova regra pelas companhias investidas. Cf. COMISSÃO DE VALORES MOBILIÁRIOS. Instrução Normativa $n^{o}$ 578, de 03 de agosto de 2016. Disponível em: <www.cvm.gov.br>. Acesso em 30 abril.2017. 33 Conforme a atual redação do inciso I do art. 16 da IN 578/16, as companhias investidas pelo FIP - Empresas Emergentes devem ter receita bruta anual de até R\$300.000.000,00 (trezentos milhões de reais) apurada no exercício social encerrado em ano anterior ao primeiro aporte do fundo, sem que tenha apresentado receita superior a esse limite nos últimos 3 (três) exercícios sociais. COMISSÃO DE VALORES MOBILIÁRIOS. Instrução Normativa $n^{\circ} 578$, de 03 de agosto de 2016. Disponível em <www.cvm.gov.br>. Acesso em 30 abril.2017.
} 
Entretanto, a viabilização dos investimentos em capital de risco no Brasil só se tornou efetiva após a implantação do Plano Real, em 1994, o qual permitiu o controle da inflação e a estabilidade. Além disso, o programa de desestatização, implementado durante a década de 90 , foi um marco importante para a implementação dos fundos de capital de risco, vez que algumas das empresas privatizadas foram compradas justamente por fundos de Private Equity.

Ainda nesta época, o setor foi movimentado sobretudo pelos bancos nacionais, que investiram de forma diversificada em empresas privatizadas, que encontravam-se em diferentes estágios de desenvolvimento ${ }^{34}$.

A retração dos investimentos veio em 1998, devido à desvalorização do real e a crise na Ásia e na Rússia - que provocou uma desconfiança em relação aos mercados emergentes e ocasionam efetiva redução nos investimentos.

Durante o período conhecido como "bolha da internet", a captação de recursos foi, novamente, alavancada. Consequentemente, esse foi o ano da criação da Associação Brasileira de Private Equity (ABVCAP), que visa o desenvolvimento de investimentos de longo prazo enquadráveis no conceito de capital de risco. A associação representa a indústria de capital empreendedor, como empresas gestoras de fundos $\mathrm{PE} / \mathrm{VC}$, o que se mostrou altamente relevante na reestruturação do mercado brasileiro após o revés do "estouro da bolha da internet".

Os anos subsequentes foram marcados por uma baixa atratividade para os investimentos de capital de risco nos mercados emergentes. Entre 2000 e 2004, fatores externos e internos causaram essa tendência: no plano mundial,

34 BERNARDINO, Diogo. Fundos de Venture Capital e Private Equity: breve análise sobre sua evolução, características e importância. Revista de Direito Bancário e Mercado de Capitais, São Paulo, v. 61, p.50, jul./set. 2013. Trimestral. 
os atentados de 11 de setembro de 2001 provocaram forte incerteza política e econômica; no ambiente doméstico, a eleição de Luís Inácio Lula da Silva causou desconfiança nos investidores ${ }^{35}$.

Em contrapartida, em 2003, a CVM emitiu a IN 391/03, definindo as regras para uma nova modalidade de fundos com foco em Private Equity e Venture Capital: os Fundos de Investimentos em Participações ("FIPs”). Essa iniciativa contribuiu para conferir um novo impulso à indústria de capital de risco nacional ${ }^{36}$.

O intervalo de 2005 a 2010 é visto como a época de amadurecimento do capital de risco brasileiro ${ }^{37}$. Os dados do censo brasileiro de Private Equity e Venture Capital registram que o capital comprometido era de aproximadamente US\$ 6 bilhões, em 2005, equivalente a apenas 0,7\% do PIB. Em 2009 o montante subiu para aproximadamente US\$ 36,1 bilhões, correspondente a $2,3 \%{ }^{38}$ do PIB $^{39}$.

Ainda, em 2005, com o surgimento do novo segmento especial de listagem no mercado de balcão organizado, o BOVESPA MAIS, as pequenas e médias empresas objeto de investimentos de capital de risco passaram a ter uma opção menos custosa como alternativa de desinvestimento. Embora ainda incipiente, esse segmento deve ser considerado uma alternativa de desinvestimento proveitosa, e menos custosa, pelos gestores dos fundos de $\mathrm{PE} / \mathrm{VC}$.

35 BERNARDINO, Diogo. Fundos de Venture Capital e Private Equity: breve análise sobre sua evolução, características e importância. Revista de Direito Bancário e Mercado de Capitais, São Paulo, v. 61, p.56, jul./set. 2013. Trimestral.

36 Ibidem.

37 Ibidem.

38 Ibidem.

39 AGÊNCIA BRASILEIRA DE DESENVOLVIMENTO INDUSTRIAL. A indústria de Private Equity e Venture Capital: $2^{\circ}$ Censo Brasileiro. Brasília, 2011. p. 64. Disponível em: < http://www.abdi.com.br/Estudo/Private_Equity_e_Venture_Censo.pdf $>$. Acesso em: 23 abril. 2017. 
O gráfico abaixo apresenta a evolução da captação de recursos anual em PE/VC neste período:

\section{Gráfico 3. - Evolução do Capital Comprometido Alocado ao Brasil em US\$ Bilhões}

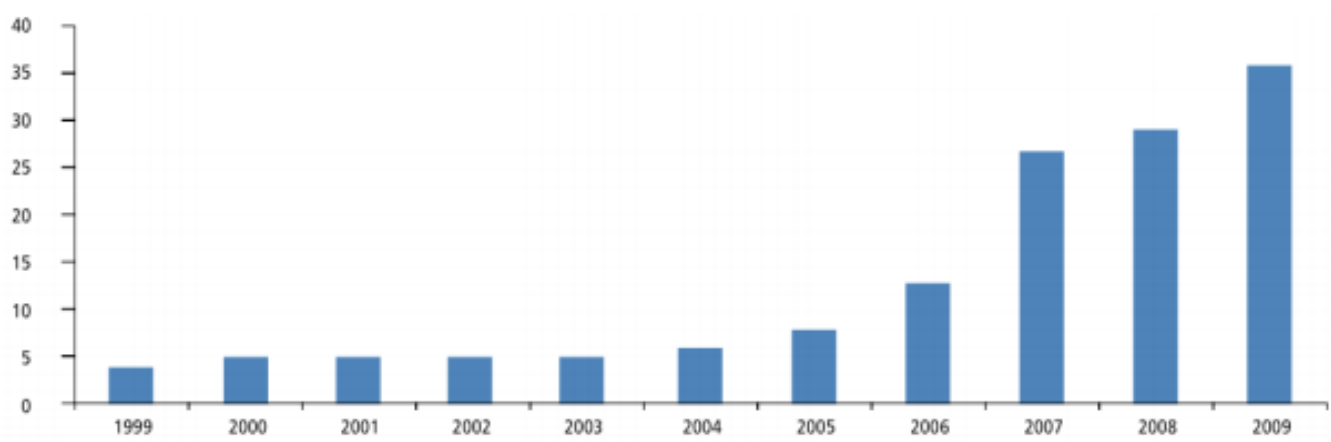

Fonte: Agência Brasileira de Desenvolvimento Industrial - 2010

O avanço da modalidade de investimento no âmbito nacional pode ser explicado por alguns fatores - dentre eles, está a expressiva queda das oportunidades de aplicações de alta performance em países diretamente afetados pela crise financeira de 2008 e 2009 - como os Estados Unidos e os países da Zona do Euro $^{40}$ - o que aumentou a procura por alternativas nos países emergentes; e a explosão de IPOs (Initial Public Offering), ocorrida entre 2006 e $2007^{41}$.

Quando comparado com a indústria do capital de risco dos demais países da América-Latina, percebemos o quanto essa área de indústria brasileira evoluiu: em 2010, os investimentos desta natureza chegaram a US\$

40 BERNARDINO, Diogo. Fundos de Venture Capital e Private Equity: breve análise sobre sua evolução, características e importância. Revista de Direito Bancário e Mercado de Capitais, São Paulo, v. 61, p.57, jul./set. 2013. Trimestral.

41 O Brasil respondeu a $30 \%$ das IPOs nos anos de 2006 e 2007 e cerca de 1/3 de todas as fusões e aquisições envolvendo Private Equity em 2010. Cf. GROH, Alexander; LIECHTENSTEIN, Heinrich; LIESER, Karsten. Iese Business School - University of Navarra - Ernesty \&Yong. The Global venture capital and private equity Country Attractiveness Index. Disponível em: <http://blog.iese.edu/vcpeindex/brazil>. Acesso em: 23 abril. 2017 
4,6 bilhões, ou seja, $69 \%$ do montante destinado à indústria latino-americana de Private Equity ${ }^{42}$.

Dentro desse cenário, o Brasil passou a ser considerado o segundo mais interessante alvo de investimento dentre os BRICs (Brasil, Rússia, Índica e China), países da CEE (Comunidade Econômica Europeia) e países da África e Oriente $\mathrm{Médio}^{43}$.

Inobstante o aquecimento da economia, internamente, vários fatores contribuíram para um crescimento mais lento e menor apetite ao risco entre os investidores, dentre eles: políticas negligentes por parte do governo, bancos centrais e comerciais, criando desequilíbrios na economia; uma política monetária acomodada adotada pelo governo, e expansão significante dos gastos públicos em um ambiente de baixo nível de desemprego; e ainda, uma lacuna de infraestrutura persistente ${ }^{44}$.

\begin{abstract}
Com o esgotamento do crescimento liderado pelo consumidor e um ambiente externo menos favorável, o Brasil entrou em um período de crescimento lento e inflação crescente, o que obrigou o Banco Central a elevar os juros. Todos esses fatores tiveram um forte efeito sobre o mercado de ações brasileiro, reduzindo as expectativas dos investidores para os ganhos futuros das empresas e aumentando o prêmio de risco global para investimentos no país. Como consequência, março 2014 a Standard \& Poors rebaixou a classificação do Brasil para BBB, o primeiro movimento de descida do rating do país na última década. (PRICEWATERHOUSECOOPERS, 2014, trad. livre) ${ }^{45}$.
\end{abstract}

42 INSEAD; PRICEWATERHOUSECOOPERS. Study on private Equity in Brazil. Disponível em $<$ www.insead.edu/facultyresearch/centres/global_private_equity_iniciative/publications/document s/INSEAD_PwC_Brazil> Acesso em: 23 abril. 2017.

43 AGÊNCIA BRASILEIRA DE DESENVOLVIMENTO INDUSTRIAL. A indústria de Private Equity e Venture Capital: $2^{o}$ Censo Brasileiro. Brasília, 2011. p. 59. Disponível em: < http://www.abdi.com.br/Estudo/Private_Equity_e_Venture_Censo.pdf>. Acesso em: 23 abril. 2017. 44 Cf. PRICEWATERHOUSECOOPERS (Brasil) (Org.). ISEAD - PwC Study on Private Equity in Brazil: Brazilian Private Equity: A New Direction. 2014. Disponível em: $<$ http://centres.insead.edu/global-private-equity-

initiative/researchpublications/documents/INSEAD_PwC_BrazilianPE_NewDirection_2014.pdf.> Acesso em: 23 abril. 2017.

45 "With the exhaustion of the consumer-led growth and a less supportive external environment, Brazil went into a period of slow growth and increasing inflation, which forced the central bank to raise interest rates. All these factors had a strong effect on the Brazilian stock market, lowering investors' expectations for companies' future earnings and increasing the overall risk premium for investments in the country. As a consequence, in March 2014 Standard \& Poor's downgraded Brazilian rating to BBB, the first downward movement in the country's rating in the past decade". Ibidem. 
A conjugação de todos os fatores destacados acima ocasionou o decréscimo na captação de recursos para a indústria de Private Equity no país, conforme demonstrado no gráfico abaixo:

\section{GRÁFICO 4. Captação de recursos para Private Equity no Brasil (2011-} 2013)

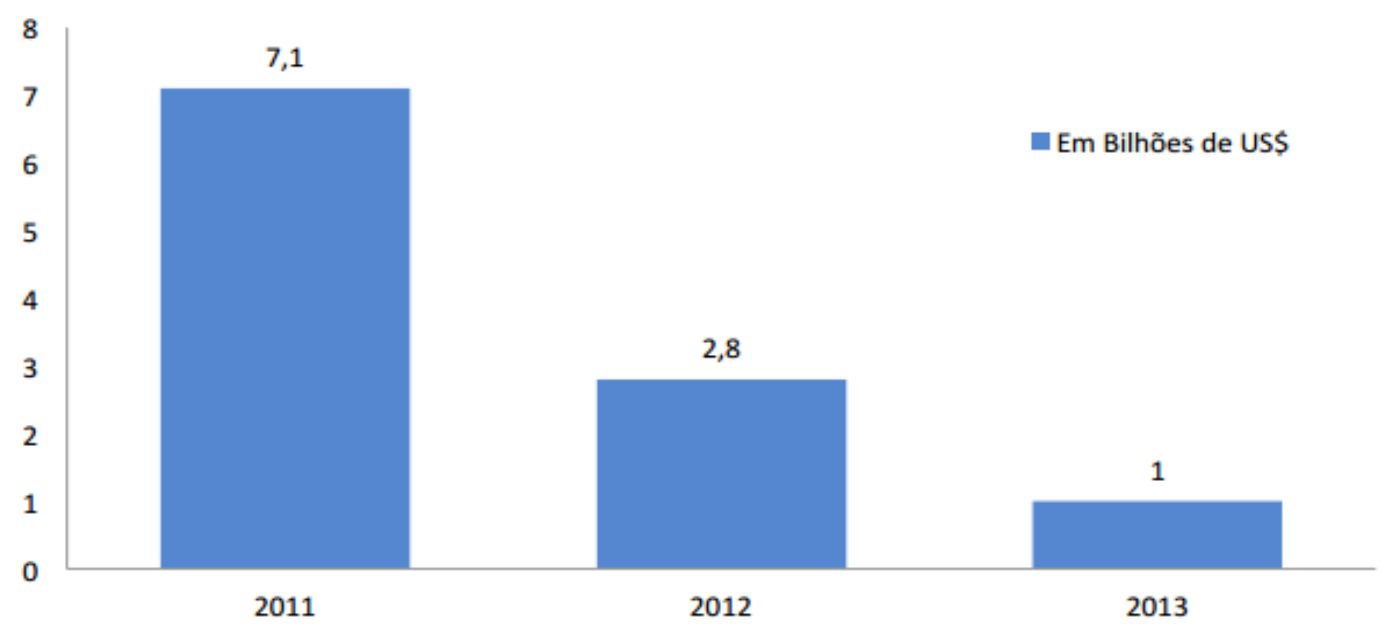

Fonte: PRICEWATERHOUSECOOPERS - 2014

A última década foi evidenciado grandes avanços no mercado de capitais brasileiro. O último semestre de 2016 foi um período de avanços na ceara legislativa para a indústria de capital de risco. A primeira mudança relevante ocorre na regulamentação dos veículos de investimento mais utilizado nesta indústria, os fundos de investimento em participações (FIPs) - com a edição pela IN no 578 , em 31 de agosto de 2016 - que estabelece uma nova regulação para a constituição, o funcionamento e a administração dos FIPs.

A nova instrução traz mudanças que tiveram uma avaliação positiva entre os participantes da indústria de PE/VC. Os FIPs passam a ser divididos em cinco categorias: capital-semente; empresas emergentes; infraestrutura; produção econômica intensiva em pesquisa, desenvolvimento e inovação 
(PD\&I); e multiestratégia ${ }^{46}$. As novas regras incorporaram características específicas da indústria do Private Equity, como a limitação da concentração de ativos ${ }^{47}$.

A mudança mais marcante na nova instrução é a possibilidade de FIPs constituídos no Brasil realizarem investimentos no exterior, antes vedados. A categoria FIPs Multiestratégia poderá alocar até $100 \%$ do seu capital subscrito em ativos no exterior, sem exigência de percentual mínimo, enquanto que às demais categorias esse percentual é limitado a $20 \%$ do capital subscrito ${ }^{48}$. As demais alterações que esta Instrução Normativa causou na regulamentação dos FIPs serão abordadas em momento oportuno neste trabalho. Cabe ressaltar que a IN 578/16 foi bem recebida pelo mercado, que enxergou a nova instrução como um progresso para a indústria de capital de risco.

Outro avanço relevante surge através da Lei Complementar 155, sancionada em outubro de 2016 - que, ao alterar a Lei do Simples Nacional, instituiu a possibilidade de sociedades enquadradas como microempresas ou empresas de pequeno porte ${ }^{49}$ receberem aportes de capital por investidores

46 Os FIPs multiestratégia prometem ser, na prática, o mais popular, pois todos os fundos que não se enquadrarem nas demais categorias, inclusive os que aplicam no exterior entrarão nessa classificação. Cf. YOKOI, Yuki. Nova regra para FIPs moderniza indústria de private equity. Capital Aberto. Edição 46. Publicado em 02 de setembro de 2016. Disponível em: < https://capitalaberto.com.br/temas/gestao-de-recursos/nova-regra-para-fips-moderniza-industriade-private-equity/\#.WRcfxlMrKJA >. Acesso em: 15 maio. 2017.

47 Originalmente, o cálculo era feito com base no patrimônio líquido, assim como já acontece em todo o restante da indústria de fundos. Os FIPs, no entanto, costumam fazer chamadas de capial conforme encontram novos ativos para investimento. Por isso, seus limites de concentração de ativos vão levar em consideração o capital subscrito. Cf. YOKOI, Yuki. Nova regra para FIPs moderniza indústria de private equity. Capital Aberto. Edição 46. Publicado em 02 de setembro de 2016. Disponível em: <https://capitalaberto.com.br/temas/gestao-de-recursos/nova-regra-para-fipsmoderniza-industria-de-private-equity/\#.WRcfxlMrKJA >. Acesso em: 15 maio. 2017.

48 Cf. Instrução CVM 578 moderniza modo de funcionamento dos FIPs. Publicado em 31 agosto. 2016. Disponível em: < http://www.cnf.org.br/noticia/-/blogs/instrucao-cvm-578-moderniza-modode-funcionamento-dos-fips >. Acesso em: 15 maio. 2017.

49 As microempresas ou empresas de pequeno porte são empresas com faturamento anual de até R $\$$ 4,8 milhões. Cf. Art. $3^{\circ}$ da Lei Complementar 123, de 14 de dezembro de 2016, conforme editada: "Art. $3^{\circ}$ Para os efeitos desta Lei Complementar, consideram-se microempresas ou empresas de pequeno porte, a sociedade empresária, a sociedade simples, a empresa individual de responsabilidade limitada e o empresário a que se refere o art. 966 da Lei no 10.406, de 10 de janeiro 
(pessoas físicas ou jurídicas ou, ainda, fundos de investimentos) que não integram seus respectivos capitais sociais e, consequentemente, não são considerados sócios das sociedades investidas, não respondendo por qualquer dívida dessas sociedades ${ }^{50}$.

Se por um lado esta lei limita a responsabilização dos veículos de Venture Capital no momento que investem nas startups, acerca de eventuais demandas trabalhistas, fiscais e falimentares que estas empresas podem futuramente sofrer, por outro, ela também restringe o período de investimento (máximo e 7 anos), de remuneração (máximo de 5 anos), de resgate (mínimo de 2 anos), e da remuneração do investidor nestes negócios (que não poderá exceder $50 \%$ dos lucros da startup) ${ }^{51}$.

Embora seja cedo para analisar como essas mudanças influenciarão os investimentos e se as perspectivas de retorno financeiro atrairão interessados, podemos afirmar que, considerando o atual ambiente de negócios brasileiro, a sanção à nova lei, além de alinhar o Brasil às tendências mundiais do segmento, abriu um largo horizonte de expectativas muito positivas àqueles que empreendem ou pretendem empreender no Brasil, no mercado de startups $^{52}$.

de 2002 (Código Civil), devidamente registrados no Registro de Empresas Mercantis ou no Registro Civil de Pessoas Jurídicas, conforme o caso, desde que: I - no caso da microempresa, aufira, em cada ano-calendário, receita bruta igual ou inferior a R \$ 360.000,00 (trezentos e sessenta mil reais); e II - no caso de empresa de pequeno porte, aufira, em cada ano-calendário, receita bruta superior a $\mathrm{R} \$$ $360.000,00$ (trezentos e sessenta mil reais) e igual ou inferior a $\mathrm{R} \$ 4.800 .000,00$ (quatro milhões e oitocentos mil reais."

50 Consequentemente, é inaplicável o artigo 50 do Código Civil, que dispõe sobre a desconsideração da personalidade jurídica, em qualquer tipo de situação, incluindo os casos de recuperação judicial, ou inadimplência de dívidas trabalhistas e fiscais. Cf. ROCHA. Luciano Velasque; WATANABE. Ricardo Ryohei L. Lei do investidor anjo alinha o Brasil às tendências mundiais. Revista Consultor Jurídico, publicada em 23 de novembro de 2016, 6h22. Disponível em: < http://www.conjur.com.br/2016-nov-23/lei-investidor-anjo-alinha-brasil-tendencias-mundiais >. Acesso em 12 janeiro. 2017.

51 ROCHA. Luciano Velasque; WATANABE. Ricardo Ryohei L. Lei do investidor anjo alinha o Brasil às tendências mundiais. Revista Consultor Jurídico, publicada em 23 de novembro de 2016, 6h22. Disponível em: < http://www.conjur.com.br/2016-nov-23/lei-investidor-anjo-alinha-brasiltendencias-mundiais >. Acesso em 12 janeiro. 2017.

52 ROCHA. Luciano Velasque; WATANABE. Ricardo Ryohei L. Lei do investidor anjo alinha o Brasil às tendências mundiais. Revista Consultor Jurídico, publicada em 23 de novembro de 2016, 
Os especialistas entendem que a queda da indústria de $\mathrm{PE} / \mathrm{VC}$ nos últimos anos é uma boa oportunidade de compra para investidores, vez que os preços estão atingindo níveis atrativos. Ademais, os negócios voltados à infraestrutura e agrobusiness impulsionam o mercado e mantém a expectativa de retorno dos investimentos de longo prazo como positiva. Dessa forma, o período é considerado um amadurecimento da indústria ${ }^{53}$.

6h22. Disponível em: < http://www.conjur.com.br/2016-nov-23/lei-investidor-anjo-alinha-brasiltendencias-mundiais >. Acesso em 12 janeiro. 2017.

53 XAVIER, Mateus Eckert. Segurança Jurídica nas Operações de Private Equity e Venture Capital. 2015. p.20. Disponível em: <https://repositorio.ufsc.br/handle/123456789/133935>. Acesso em 23 abril. 2017 


\section{CAPÍTULO 2. CARACTERÍSTICAS DO INVESTIMENTO}

O investimento de capital de risco pode ser definido como uma atividade de participação acionária em uma empresa, na maioria dos casos envolve empresas ainda em desenvolvimento, acentuando o aspecto mais dinâmico, arriscado e aventureiro do investimento realizado. É, portanto, uma modalidade de financiamento que pressupõe um alto risco em troca de perspectiva de um alto retorno para o veículo investidor, e indiretamente, para seus investidores e seu gestor ${ }^{54}$.

O veículo investidor de risco "aposta" na empresa a ser investida ${ }^{55}$. Ao adquirir ações, e/ou outros títulos da sociedade alvo, ele torna-se sócio da companhia, e dessa forma, sua remuneração se dá por meio da distribuição de dividendos (lucros) e do ganho de capital mediante a venda de ações para terceiros. Por conseguinte, ao tornar-se sócio, o investidor deixa de ser um mero "fornecedor de capital", e passa a ser de alto envolvimento, muitas vezes participando da gerência do negócio.

Por envolver investimentos aplicados em empresas que se encontram em seus estágios embrionários de desenvolvimento, onde as taxas de insucesso são mais elevadas quando comparadas com as empresas listadas em bolsa e/ou consolidadas em seu mercado de atuação, os fundos de Private Equity e Venture Capital são considerados modalidades de investimento de alto risco ${ }^{56}$. Em contrapartida, tendo em vista a óbvia correlação entre risco e retorno, são investimentos que apresentam potencial de retorno muito mais elevado.

54 NITA. Kleber de Freitas. O Ciclo de Investimento do Capital de Risco no Brasil e as Modalidades de Private Equity e Venture Capital. Trabalho de conclusão de curso. Curso de Ciências Econômicas. Universidade Federal de Santa Catarina, Florianópolis, 2008.

55 PAVANI, C. O Capital de Risco no Brasil: Conceito, Evolução e Perspectivas. Rio de Janeiro: E-papers, 2003.

56 ENEI, José Virgílio Lopes. O capital de risco e o private equity no Brasil: a nova lógica do investimento. In: ADAMEK, Marcelo Vieira Von (Coord.). Temas de direito societário e empresarial contemporâneos. p. 720. São Paulo: Malheiros, 2011. 
A dinâmica de estruturação da indústria de capital de risco é muito similar no mundo inteiro: Investidores comprometem ou confiam seus recursos a fundos de investimento, ou limited partnerships ${ }^{57}$, geridos e administrados por gestores profissionais e especializados em empresas emergentes e em desenvolvimento. Sob a gestão de tais profissionais, esses fundos ou partnerships realizam investimentos e adquirem participações, minoritárias ou majoritárias, em empresas de capital fechado, passando a participar de sua governança. Por fim, ao final de um período de 3 a 10 anos, tais investimentos precisam ser liquidados, e os resultados financeiros restituídos ao fundo, e deste aos investidores..$^{58}$

Essa modalidade de investimento visa a participação acionária, porém, embora os investidores possam contribuir para a empresa target com recursos de capital, muitas vezes é a sua participação na administração e controle da sociedade que o torna tão atrativo, já que proporciona o seu desenvolvimento e crescimento estratégico da sociedade investida ${ }^{59}$.

Sob o prisma da empresa financiada, os investimentos de Venture Capital e Private Equity cumprem o papel de permitir à empresa e seu empreendedor financiar seus estágios iniciais de desenvolvimento, implantar seu produto ou negócio, conquistar o mercado e, assim, alcançar o nível de

\footnotetext{
57 Segundo a lei da quase totalidade dos Estados norte-americanos e a legislação fiscal federal, a partnership é entendida sem personalidade fiscal própria, tal qual nossos fundos, transmitindo aos seus sócios os lucros e perdas na proporção de suas participações. Contudo, ao contrário de nossos consórcios, as limited partnerships conferem limitação de responsabilidade ao sócio como se fossem verdadeiras limitadas. Não obstante, alguns fundos brasileiros oferecem também tal limitação de responsabilidade aos seus quotistas, como é o caso do fundo imobiliário e o fundo de investimento em participações, os quais respondem pelas obrigações assumidas no cumprimento das atividades que compõem seu objeto, mas apenas nos limites do seu patrimônio, sem que os quotistas fiquem obrigados a repor eventuais insuficiências. (ENEI, José Virgílio Lopes. O capital de risco e o private equity no Brasil: a nova lógica do investimento. In: ADAMEK, Marcelo Vieira Von (Coord.). Temas de direito societário e empresarial contemporâneos. p. 719. São Paulo: Malheiros, 2011).

58 ENEI, José Virgílio Lopes. O capital de risco e o private equity no Brasil: a nova lógica do investimento. In: ADAMEK, Marcelo Vieira Von (Coord.). Temas de direito societário e empresarial contemporâneos. p. 719. São Paulo: Malheiros, 2011.
}

59 Ibidem. 
amadurecimento que lhes permita, em momento propício, acessar o mercado de capitais e alcançar sua independência financeira com condições mais favoráveis ${ }^{60}$.

Além disso, o investimento de capital em empresas em desenvolvimento tem o condão de alavancar duas ou três vezes mais recursos na forma de endividamento - já que o investidor PE/VC pode oferecer uma parcela relevante do capital próprio que seria usado pela sociedade investida, concedendo financiamento em valor ainda maior que as instituições financeiras estariam dispostas a fornecer àquele empreendimento. ${ }^{61}$

Os próximos tópicos apresentarão uma breve explicação da lógica da indústria de capital de risco, passando pelos principais participantes envolvidos, os diferentes estágios de desenvolvimento dos negócios, assim como as cinco fases do ciclo dos investimentos de Venture Capital e Private Equity.

\subsection{Os principais participantes}

A essência do funcionamento desta indústria pode ser entendida através da análise do papel dos principais participantes no processo de investimento.

Por ser uma análise de investimento substancialmente mais complexa que os demais investimentos ${ }^{62}$, os investidores em papéis desta natureza tendem a fazer parte de um público mais restrito - os chamados "investidores

60 ENEI, José Virgílio Lopes. O capital de risco e o private equity no Brasil: a nova lógica do investimento. In: ADAMEK, Marcelo Vieira Von (Coord.). Temas de direito societário e empresarial contemporâneos. p. 717. São Paulo: Malheiros, 2011.

61 Ibidem.

62 A análise dos investimentos em Private Equity e Venture Capital é substancialmente mais complexa do que a maioria dos investimentos, pois não há taxa de retorno pré-fixada ou facilmente determinável, já que os rendimentos positivos dependem de inúmeros aspectos que, na maioria dos casos, são de difícil mensuração. In.___ BERNARDINO, Diogo. Fundos de Venture Capital e Private Equity: breve análise sobre sua evolução, características e importância. Revista de Direito Bancário e Mercado de Capitais, São Paulo, v. 61, p.55, jul./set. 2013. Trimestral. 
institucionais" ou "qualificados"63 - que, em geral compreendem instituições financeiras, seguradoras, fundos de pensão, fundos de investimento, grandes empresas e pessoas físicas com elevado patrimônio e prévia experiência no mercado de capitais.

No Brasil, os fundos institucionais ou corporativos são os que aparecem de forma mais impactante nesta estrutura ${ }^{64}$. Os demais investimentos são feitos por pessoais naturais, chamadas de angels investors, indivíduos, pessoas físicas empreendedoras, que investem o seu patrimônio próprio, com uma carteira bem sucedida ${ }^{65}$.

Uma vez que as taxas de insucesso são elevadas, os investidores qualificados tendem a depositar apenas uma parcela estrategicamente calculada a essa espécie de investimento, para assim diversificar a sua carteira, sob um nível de risco aceitável ${ }^{66}$.

Na estrutura típica de um Venture Capital e Private Equity, os investidores qualificados canalizam os seus recursos em um veículo,

63 Segundo a IN CVM n ${ }^{\circ}$ 554, de 17 de dezembro de 2014, “Art. $9^{\circ}$-B São considerados investidores qualificados: I - investidores profissionais; II - pessoas naturais ou jurídicas que possuam investimentos financeiros em valor superior a $\mathrm{R} \$ 1.000 .000,00$ (um milhão de reais) e que, adicionalmente, atestem por escrito sua condição de investidor qualificado mediante termo próprio, de acordo com o Anexo 9-B; III - as pessoas naturais que tenham sido aprovadas em exames de qualificação técnica ou possuam certificações aprovadas pela CVM como requisitos para o registro de agentes autônomos de investimento, administradores de carteira, analistas e consultores de valores mobiliários, em relação a seus recursos próprios; e IV - clubes de investimento, desde que tenham a carteira gerida por um ou mais cotistas, que sejam investidores qualificados."

64 Em 2011, os fundos de pensão eram responsáveis por 22\% da alocação do capital comprometido, já os bancos contribuiram com $10 \%$, family office com $9 \%$, e $7 \%$ eram provenientes dos fundos de investimentos. In: CHAMEIN, Sidney. A viabilidade dos projetos alternativos no Brasil. Disponível em: <http://www.investidorinstitucional.com.br/index.php/br/investidores/fundosdepensao/145revista-investidor-institucional.html?limit=10\&start=240>. Acesso em: 29 abril. 2017.

$65 \mathrm{Em}$ troca do investimento efetuado, esses investidores recebem uma parcela do capital da empresa ou promessa de retorno do seu investimento com rentabilidade pré-determinada ou relacionada ao desempenho do negócio, caso bem sucedido. Sua presença é maior nos países com mercados de capitais bem desenvolvido, como os Estados Unidos e a Inglaterra. In__ NITA. Kleber de Freitas. O Ciclo de Investimento do Capital de Risco no Brasil e as Modalidades de Private Equity e Venture Capital. Trabalho de conclusão de curso. Curso de Ciências Econômicas. Universidade Federal de Santa Catarina, Florianópolis, 2008.

66 ENEI, José Virgílio Lopes. O capital de risco e o private equity no Brasil: a nova lógica do investimento. In: ADAMEK, Marcelo Vieira Von (Coord.). Temas de direito societário $e$ empresarial contemporâneos. p. 720. São Paulo: Malheiros, 2011. 
usualmente um fundo, uma sociedade holding ou uma partnership, justamente por serem geridos por profissionais altamente especializados nesse segmento ${ }^{67}$. José Virgílio Lopes Enei explica que "tal estrutura faz-se usualmente necessária para dotar tal veículo de volume suficiente para negociar com eficiência investimentos em um conjunto de empresas-alvo, durante certo período de investimento"68.

Nos países filiados à corrente anglo-saxã do Direito, as limited partnerships - e suas variações - são as entidades mais utilizadas para realizar esse papel. A essas entidades é reconhecida capacidade para contratar em nome próprio, tomar financiamento e participar ativamente da gestão de outros negócios, sem, contudo, se qualificarem como entes tributáveis independentes e separados de seus sócios, o que lhes confere grande eficiência tributária. Enquanto que a gestão das limited partnerships compete ao general partner, o limited partner é responsável apenas pelas contribuições pecuniárias ${ }^{69}$.

Cabe destacar, no entanto, que embora a tradução literal do termo possa causar confusão com o instituto brasileiro das sociedades por quotas de responsabilidade limitada, não há instituto jurídico que se assemelhe às limited partnerships ${ }^{70}$.

Além de não participarem da gestão da limited partnership, o vínculo dos limited partners é exclusivamente contratual (estipulado através do limited partnership agreement) - o que diferente das nossas sociedades limitadas, onde os sócios são os que efetivamente decidem os rumos da sociedade, por meio de suas deliberações e previsões inseridas no contrato

67 Ibidem. p. 722.

68 Ibidem.

69 Ibidem.

70 BERNARDINO, Diogo. Fundos de Venture Capital e Private Equity: breve análise sobre sua evolução, características e importância. Revista de Direito Bancário e Mercado de Capitais, São Paulo, v. 61, p.56, jul./set. 2013. Trimestral. 
social. Ademais, diferentemente das sociedades limitadas, não há feição corporativa no relacionamento entre os limited partners e os manger partners, e tampouco é concedida personalidade jurídica às limited partnerships ${ }^{71}$.

No Brasil, os investimentos de Venture capital e Private Equity são realizados através de (i) veículos constituídos em países estrangeiros, que por sua vez, investem em empreendimentos no Brasil através de operações internacionais (cross border), com ingresso de investimento direto estrangeiro (Lei 4.131/1962), indireto (financiamentos, também na forma da Lei 4.131/1962), ou ainda, investimentos em bolsa de valores ou portfólio (Resolução CMN nº 2.689); e (ii) veículos constituídos localmente ${ }^{72}$.

Os veículos locais mais propícios aos investimentos de capital de risco, atualmente, são o fundo de investimento em participações (FIPs) (IN CVM $\left.n^{0} 578 / 2016\right)^{73}$.

Os FIPs, assim como as limited partnerships, conferem limitação de responsabilidade aos seus quotistas (que não respondem além do capital aportado ou comprometido), é neutro do ponto de vista tributário, e é administrado por um agente profissional e especializado, que não detém parcela majoritária dos investimentos ${ }^{74}$.

71 Ibidem. p.57.

72 ENEI, José Virgílio Lopes. O capital de risco e o private equity no Brasil: a nova lógica do investimento. In: ADAMEK, Marcelo Vieira Von (Coord.). Temas de direito societário e empresarial contemporâneos. p. 722. São Paulo: Malheiros, 2011.

73 Além do capital de risco atuar no mercado de crédito na forma de fundos, outras formas organizacionais são utilizadas, como (i) as subsidiárias corporativas de instituições financeiras ou de grandes empresas - as quais são fruto de recursos do caixa destas instituições, como por exemplo Intel e Votorantim; e (ii) as holdings independentes, que atuam como fundo, mas seu formato jurídico é o de uma holding, e tendem a ser constituídas em paraísos fiscais. Estas últimas, em virtude da integralização do seu capital ocorrer no exterior, a entrada de capital no país é realizada sob a rubrica capital estrangeiro. In: NITA. Kleber de Freitas. O Ciclo de Investimento do Capital de Risco no Brasil e as Modalidades de Private Equity e Venture Capital. Trabalho de conclusão de curso. Curso de Ciências Econômicas. Universidade Federal de Santa Catarina, Florianópolis, 2008.

74ENEI, José Virgílio Lopes. O capital de risco e o private equity no Brasil: a nova lógica do investimento. In: ADAMEK, Marcelo Vieira Von (Coord.). Temas de direito societário $e$ empresarial contemporâneos. p. 723. São Paulo: Malheiros, 2011. 
Com a nova Instrução Normativa 578/16, os FIPs passam a ser divididos em cinco categorias: Capital-Semente; Empresas Emergentes; Infraestrutura; Produção Econômica Intensiva em Pesquisa, Desenvolvimento e Inovação (Pd\&I); e Multiestratégia ${ }^{75}$.

As novas regras incorporaram algumas características específicas da indústria do Private Equity, como (i) a limitação da concentração de ativos ${ }^{76}$; (ii) a possibilidade dos FIPs investirem em sociedades limitadas, desde que estas apresentem receita bruta anual de até $\mathrm{R} \$ 16$ milhões; (iii) a ampliação do público alvo do FIP Capital Semente, para todos os investidores qualificados e não somente para os investidores profissionais; (iv) permissão de realização de investimentos em outras categorias por todos os FIPs; além (v) da permissão da criação de classes de cotas com distintos direitos econômicos-financeiros, dependendo do tipo de investidor ${ }^{77}$.

Uma das mudanças consideradas mais revolucionárias na nova Instrução Normativa é a possibilidade de FIPs constituídos no Brasil realizarem investimentos no exterior, antes vedados. A categoria FIPs Multiestratégia poderá alocar até $100 \%$ do seu capital subscrito em ativos no exterior, sem exigência de percentual mínimo, enquanto que às demais

\footnotetext{
75 Os FIPs multiestratégia prometem ser, na prática, o mais popular, pois todos os fundos que não se enquadrarem nas demais categorias, inclusive os que aplicam no exterior entrarão nessa classificação. Os FIPs desta categoria podem investir até $20 \%$ do capital subscrito fora do país. Cf. YOKOI, Yuki. Nova regra para FIPs moderniza indústria de private equity. Capital Aberto. Edição 46. Publicado em 02 de setembro de 2016. Disponível em: < https://capitalaberto.com.br/temas/gestao-de-recursos/nova-regra-para-fips-moderniza-industriade-private-equity/\#.WRcfxlMrKJA > Acesso em: 15 maio. 2017.

76 Originalmente, o cálculo era feito com base no patrimônio líquido, assim como já acontece em todo o restante da indústria de fundos. Os FIPs, no entanto, costumam fazer chamadas de capial conforme encontram novos ativos para investimento. Por isso, seus limites de concentração de ativos vão levar em consideração o capital subscrito. Cf. YOKOI, Yuki. Nova regra para FIPs moderniza indústria de private equity. Capital Aberto. Edição 46. Publicado em 02 de setembro de 2016. Disponível em: < https://capitalaberto.com.br/temas/gestao-de-recursos/nova-regra-para-fipsmoderniza-industria-de-private-equity/\#.WRcfxlMrKJA > Acesso em: 15 maio. 2017.

77 Instrução CVM 578 moderniza modo de funcionamento dos FIPs. Publicado em 31 agosto. 2016. Disponível em: < http://www.cnf.org.br/noticia/-/blogs/instrucao-cvm-578-moderniza-modo-defuncionamento-dos-fips $>$. Acesso em: 15 maio. 2017.
} 
categorias esse percentual é limitado a 20\% do capital subscrito. Além disso, esta categoria será voltada para investidores profissionais - com aplicação financeira superiores a $\mathrm{R} \$ 10$ milhões - e deverá utilizar o sufixo "Investimento no exterior" na sua denominação ${ }^{78}$.

Há, ainda, a possibilidade dos FIPs investirem em sociedades limitadas, o que promete afetar a indústria de PE/VC como um todo - vez que a lógica tradicional dessa modalidade de investimento é a exploração de atividades exercidas por companhias fechadas.

Ademais, ao entrarem nesta indústria, esses fundos de investimentos, sobretudo os FIPs, romperam com o perfil passivo tradicional dos fundos de investimento no Brasil, onde o papel do respectivo administrador não contemplava participação relevante e ativa na governança dos ativos investidos. Por conseguinte, a doutrina mais moderna passou a reconhecer a personalidade jurídica própria desses fundos de investimento que têm o papel mais atuante na gestão das sociedades investidas, para além de capacidades contratual, postulatória, etc" "9. Sobre o tema, Jorge Lobo, em "Fundos de private equity" ${ }^{80}$, defende que:

\begin{abstract}
A meu ver, os 'fundos de private equity' caso sociedades não personificadas autorizadas, pela CVM, a captar recursos financeiros de investidores qualificados por longo ou predeterminado prazo de duração, para aplicação no mercado financeiro, de capitais, futuro ou outros ativos, preferencialmente sob a forma de participações societárias relevantes em companhias com grande potencial de geração de caixa, de lucros e de valorização das ações, sob a exclusiva responsabilidade do administrador com poderes absolutos e discricionários, que atuará na implementação da política de investimentos e do plano estratégico em benefício dos cotistas.
\end{abstract}

78 Ibidem.

79 FREITAS. Ricardo de Santos, Natureza Jurídica dos Fundos de Investimento, São Paulo, Quartier Latin, 2006.

80 LOBO, Jorge. Fundos de private Equity. In PERIN, Ecio Jr., KALANSKY, Daniel e PEYSER, Luís (Coords.). Direito Empresarial: Aspectos Atuais do Direito Empresarial Brasileiro $e$ Comparado, p. 103-110. São Paulo: Método, 2005. 
Essa postura mais ativa na governança dos ativos investidos pelos FIPs passou a ser dispensada pela IN 578/16, sempre que (i) o investimento do FIP na sociedade for reduzido a menos da metade do percentual originalmente investido e passe a representar parcela inferior a $15 \%$ do capital social da investida; e (ii) o valor contábil do investimento tenha sido reduzido a zero e haja deliberação dos cotistas aprovada por maioria simples, caso o regulamento não preveja quórum mais elevado ${ }^{81}$.

Adicionalmente, a IN 578/16 prevê que o requisito de influência na gestão não se aplica nas investidas que sejam listadas em segmento especial de negociação de valores mobiliários ou mercado de balcão organizado, que assegure padrões de governança corporativa mais rígidos que os legais, por meio de vínculo contratual, e desde que o investimento não corresponda a mais de $35 \%$ do capital subscrito do FIP ${ }^{82}$.

Por fim, o gestor dos fundos de investimento, assim como os general partner das limited partnerships é a pessoa jurídica responsável por assegurar o cumprimento, pelo fundo, de todas as providências e exigências estabelecidas em lei. ${ }^{83}$ Quanto às atividades de escrituração, custódia, informações periódicas ao órgão regulador (CVM), a IN 578/16 ampliou as responsabilidades e obrigações dos gestores, no que tange à contratação de

81 FREITAS. Bernardo Vianna; FERRAZ, Adriano Augusto Teixeira; SPRÄNGER, Leon. CVM edita novas regras para fundos de private equity e venture capital: Nova regulamentação afeta principalmente os Fundos de Investimento em Participações (FIPs) e os Fundos Mútuos de Investimento em Empresas Emergentes (FMIEEs). Migalhas. Publicada em 10 out. 2016. Disponível em: $\quad<\quad$ http://www.migalhas.com.br/dePeso/16,MI247029,81042CVM+edita+novas+regras+para+fundos+de+private+equity+e+venture+capital > Acesso em 15 maio. 2017.

82 FREITAS. Bernardo Vianna; FERRAZ, Adriano Augusto Teixeira; SPRÄNGER, Leon. CVM edita novas regras para fundos de private equity e venture capital: Nova regulamentação afeta principalmente os Fundos de Investimento em Participações (FIPs) e os Fundos Mútuos de Investimento em Empresas Emergentes (FMIEEs). Migalhas. Publicada em 10 out. 2016. Disponível em: < < http://www.migalhas.com.br/dePeso/16,MI247029,81042$\mathrm{CVM}+$ edita+novas+regras+para+fundos+de+private+equity+e+venture+capital $>$ Acesso em 15 maio. 2017.

83 ENEI, José Virgílio Lopes. O capital de risco e o private equity no Brasil: a nova lógica do investimento. In: ADAMEK, Marcelo Vieira Von (Coord.). Temas de direito societário e empresarial contemporâneos. p. 724. São Paulo: Malheiros, 2011. 
serviços relacionados ao investimento ou desinvestimento ${ }^{84}$, bem como à sua atuação na precificação dos investimentos do fundo ${ }^{85}$. Em linha com a IN 555/14, a nova instrução separa expressamente as atribuições do administrador fiduciário e do gestor de recursos.

A nova instrução ainda concedeu ao gestor do FIP poderes para representar o FIP em determinados atos, como: (i) negociar e contratar os ativos e intermediários para realizar operações do fundo, (ii) negociar e contratar terceiros para a prestação de serviços de assessoria e consultoria relacionados diretamente com o investimento e desinvestimento do fundo, (iii) monitorar os ativos do fundo e exercer o direito de voto desses ativos, observada, nesse caso, a política de voto previamente estabelecida pelo próprio gestor $^{86}$.

Essa participação tem diferentes graus que, dentre outros fatores, dependem da fase de desenvolvimento do negócio. Enquanto os investimentos de Venture Capital tendem a exigir intensa participação do gestor durante a fase de monitoramento e adição de valor para o negócio; os investimentos de Private Equity, pelo fato das empresas investidas estarem mais amadurecidas, há um menor envolvimento do gestor nos negócios.

84 "O administrador passa ainda a ser solidariamente responsável com todos os prestadores de serviços por eventuais prejuízos causados aos cotistas quanto aos serviços de tesouraria, atividades de controle e processamento de ativos e escrituração da emissão do resgate das cotas." Cf. FREITAS. Bernardo Vianna; FERRAZ, Adriano Augusto Teixeira; SPRÄNGER, Leon. CVM edita novas regras para fundos de private equity e venture capital: Nova regulamentação afeta principalmente os Fundos de Investimento em Participações (FIPs) e os Fundos Mútuos de Investimento em Empresas Emergentes (FMIEEs). Migalhas. Publicada em 10 out. 2016. Disponível em: < http://www.migalhas.com.br/dePeso/16,MI247029,81042-

CVM+edita+novas+regras+para+fundos+de+private+equity+e+venture+capital > Acesso em 15 maio. 2017.

85 Cf. Instrução CVM 578 moderniza modo de funcionamento dos FIPs. Publicado em 31 agosto. 2016. Disponível em: < http://www.cnf.org.br/noticia/-/blogs/instrucao-cvm-578-moderniza-modode-funcionamento-dos-fips >. Acesso em: 15 maio. 2017.

86 FREITAS. Bernardo Vianna; FERRAZ, Adriano Augusto Teixeira; SPRÄNGER, Leon. CVM edita novas regras para fundos de private equity e venture capital: Nova regulamentação afeta principalmente os Fundos de Investimento em Participações (FIPs) e os Fundos Mútuos de Investimento em Empresas Emergentes (FMIEEs). Migalhas. Publicada em 10 out. 2016. Disponível em: < http://www.migalhas.com.br/dePeso/16,MI247029,81042CVM+edita+novas+regras+para+fundos+de+private+equity+e+venture+capital > Acesso em 15 maio. 2017. 
É o gestor que escolhe as empresas e empreendimentos a serem objeto de investimento, monitora seu desenvolvimento, influencia ativamente sua governança e realiza o desinvestimento da forma mais eficiente possível. Dessa forma, a sua atividade é a chave de todo Private Equity e Venture Capital, sendo sua habilidade e competência determinantes para o sucesso do investimento como um todo ${ }^{87}$.

Não obstante o papel fundamental do gestor, a lógica do investimento desta natureza, via de regra, é a de uma joint venture ou parceria, em que há a combinação de esforços e competências do gestor e do empreendedor original - que é responsável pelo conhecimento técnico, tecnológico ou operacional em que se baseia o empreendimento ${ }^{88}$.

Essa influência direta no poder decisório da sociedade alvo é definida desde o contrato de investimento, mantido entre o fundo e a sociedade investida, e pode ser operacionalizada de diversas formas. Os sócios fundadores aceitam abdicar do comando pleno dos seus negócios, para em troca ter o retorno financeiro e conhecimentos corporativos por parte dos especialistas que gerem o fundo, já que estes têm larga experiência naquela indústria ${ }^{89}$.

Assim, os recursos aplicados pelos investidores no veículo de investimento são empregados em empreendimentos realizados pelo veículo, que representem bom potencial de crescimento e retorno sobre o capital investido, em horizonte de médio/longo prazo (3 a 10 anos, em média). O

87 ENEI, José Virgílio Lopes. O capital de risco e o private equity no Brasil: a nova lógica do investimento. In: ADAMEK, Marcelo Vieira Von (Coord.). Temas de direito societário e empresarial contemporâneos. p. 724. São Paulo: Malheiros, 2011.

88 Ibidem. p. 725.

89 BERNARDINO, Diogo. Fundos de Venture Capital e Private Equity: breve análise sobre sua evolução, características e importância. Revista de Direito Bancário e Mercado de Capitais, São Paulo, v. 61, p.56, jul./set. 2013. Trimestral. 
aporte é geralmente realizado na forma de ações (ordinárias ou preferenciais), quotas de participação, debêntures conversíveis, opções ou bônus de subscrição. Em contrapartida, o veículo de investimento exige participação acionária e certos direitos econômicos. Essa lógica se mantém até que os investimentos possam ser eficientemente liquidados, com o repasse dos ganhos correspondentes ao veículo e deste aos seus investidores, após o pagamento da remuneração do gestor.

A figura abaixo descreve a relação entre os diversos agentes da indústria de PE/VC, organizados em torno do veículo de investimento.

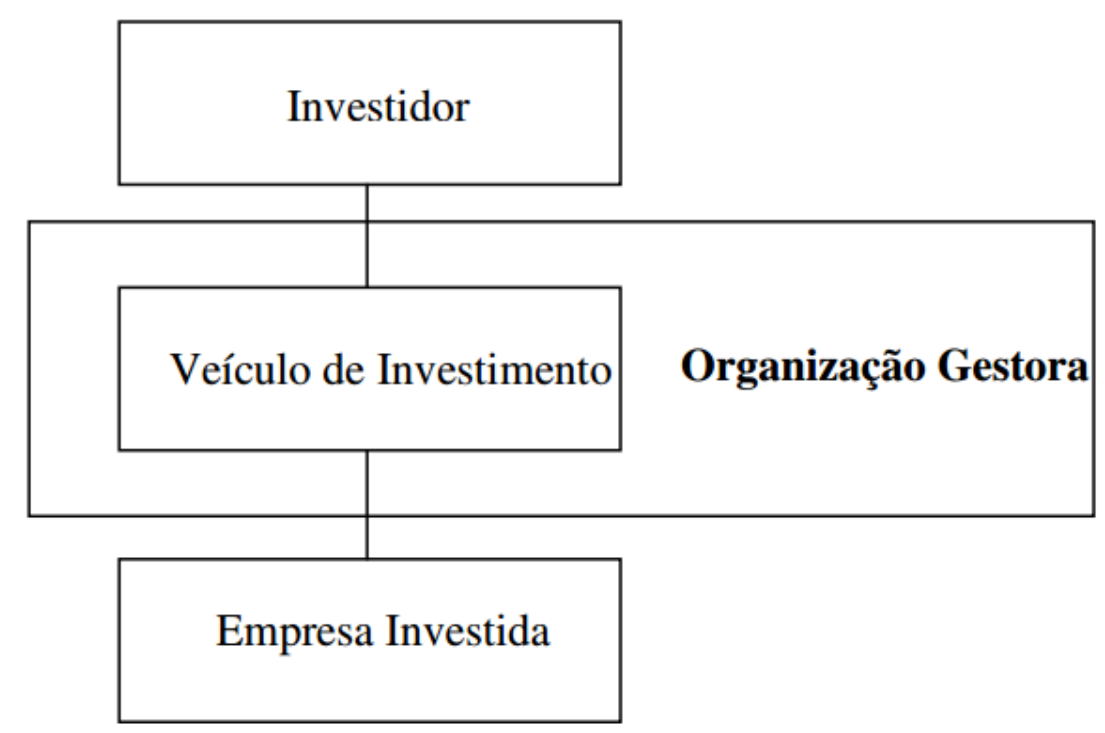

Fonte: Ribeiro (2005) $)^{90}$

Na Indústria do capital de risco, o papel do veículo de Venture Capital e Private Equity, guiado pelo seu gestor, será o de monitorar a empresa-alvo, assim como influenciar positivamente na sua governança corporativa ${ }^{91}$,

90 RIBEIRO, Leonardo de Lima. O modelo brasileiro de private equity e venture capital. Dissertação de Mestrado. Programa de pós-graduação em Administração, Universidade de São Paulo, São Paulo, 2005. Apud In: NITA. Kleber de Freitas. O Ciclo de Investimento do Capital de Risco no Brasil e as Modalidades de Private Equity e Venture Capital. Trabalho de conclusão de curso. p. 20. Curso de Ciências Econômicas. Universidade Federal de Santa Catarina, Florianópolis. 2008.

91 De acordo com o IBGC (Instituto Brasileiro de Governança Corporativa), governança corporativa é "o sistema pelo qual as sociedades são dirigidas e monitoradas, envolvendo os relacionamentos entre acionistas, Conselho de Administração, Diretoria, Auditoria Independente e Conselho Fiscal." As boas prática de governança corporativa criam mecanismos eficientes para garantir que o comportamento dos executivos responsáveis pela gestão da empresa reflita os interesses de seus 
nomeando membros capacitados para ocupar os cargos no conselho de administração, conselho fiscal e, eventualmente, para a própria diretoria ${ }^{92}$.

Além dos principais participantes do investimento de Venture Capital e Private Equity citados acima, podemos destacar ainda a atuação fundamental (i) das instituições do governo, como a Comissão de Valores Mobiliários, o Banco Central e o Comitê Monetário Nacional - responsáveis pela formulação de normas regulatórias, fiscalização e controle do segmento de Capital de Risco; (ii) de organizações de fomento, que no Brasil são representadas pela FINEP, Endeavor, Sebrae, IEL, fundações de amparo à pesquisa; (iii) de empresas de consultoria, instituto de pesquisa, empresas de auditoria, que geram informações e ajudam no processo decisório dos participantes desta Indústria; (iv) da bolsa de valores e mercado de balcão organizado - organizações responsáveis por criar e manter mercados transparentes e justos, e que permitem a saída dos investimentos através da oferta pública de ações ${ }^{93}$; e (v) de investidores estratégicos, que geralmente são empresas que buscam posicionamento no mercado através de aquisição de outras empresas.

A figura abaixo espelha como os principais participantes desse segmento de capital de risco se relacionam com as instituições/agentes acima apresentados, através de fluxos variados, considerados fundamentais para o funcionamento da indústria de Venture Capital e Private Equity:

acionistas. Dentre os principais instrumentos de fiscalização e controle da gestão das companhias, pode-se citar: um conjunto de deveres legais atribuídos aos administradores e acionistas controladores, atuação independente do Conselho de Administração e um sistema de informações eficiente. In___ NITA. Kleber de Freitas. O Ciclo de Investimento do Capital de Risco no Brasil e as Modalidades de Private Equity e Venture Capital. Trabalho de conclusão de curso. Curso de Ciências Econômicas. Universidade Federal de Santa Catarina, Florianópolis, 2008.

92 ENEI, José Virgílio Lopes. O capital de risco e o private equity no Brasil: a nova lógica do investimento. In: ADAMEK, Marcelo Vieira Von (Coord.). Temas de direito societário e empresarial contemporâneos. p. 728. São Paulo: Malheiros, 2011.

93 São entidades auto-reguladoras, ou seja, regulam e punem o comportamento dos seus membros, estabelecendo as regras das negociações. In: NITA. Kleber de Freitas. O Ciclo de Investimento do Capital de Risco no Brasil e as Modalidades de Private Equity e Venture Capital. Trabalho de conclusão de curso. Curso de Ciências Econômicas. Universidade Federal de Santa Catarina, Florianópolis, 2008. 


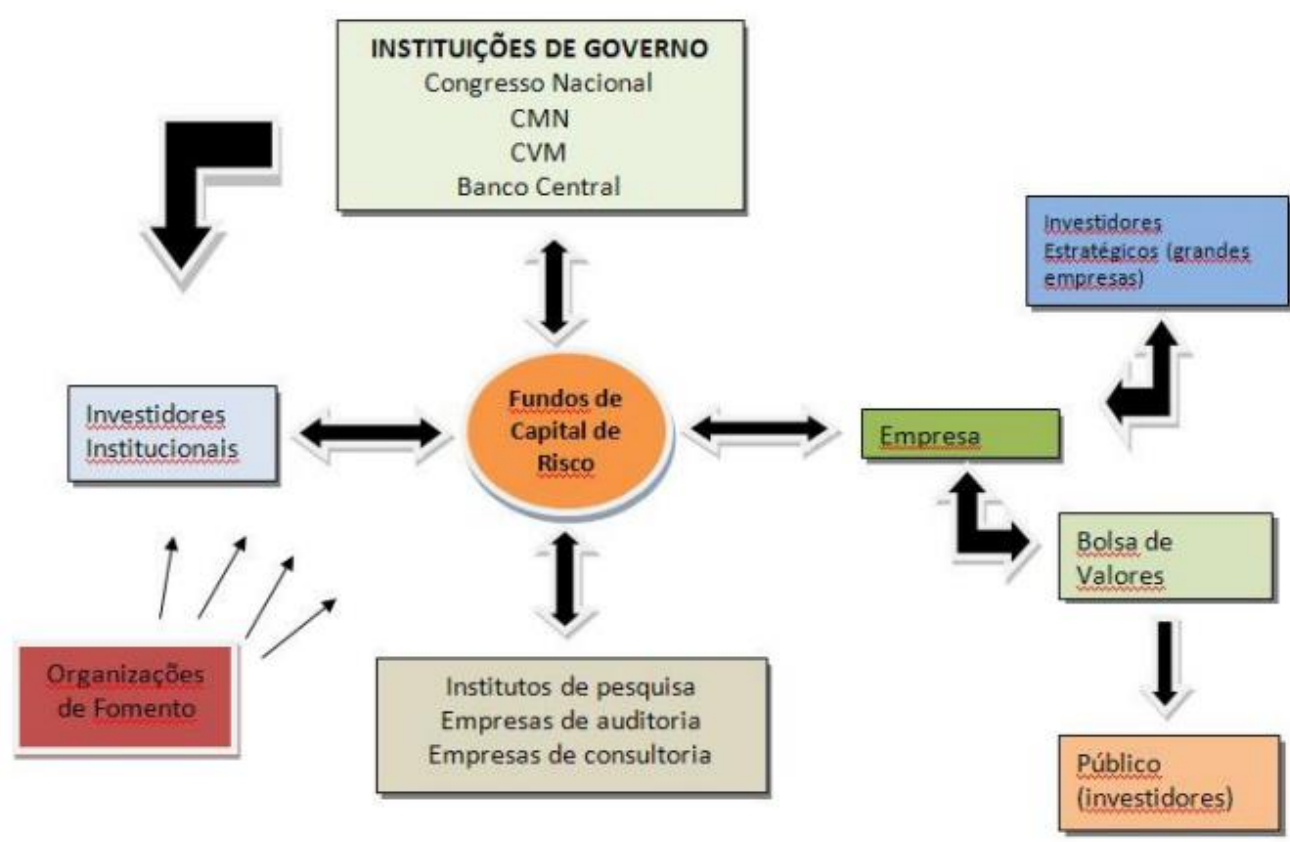

FONTE: Pavani (2003) ${ }^{94}$

\subsection{Característica principal: $o$ alto risco de investimento}

Como exposto neste trabalho, os investimentos dos fundos de Private Equity e Venture Capital apresentam alto grau de incerteza do retorno financeiro para o investidor. Pelos investimentos serem alocados em apostas em ideias prematuras, muitas vezes inovadoras, eles nem sempre resultam no êxito financeiro desejado pelos investidores.

Diogo Bernardino, em "Fundos de Venture Capital e Private Equity: breve análise sobre sua evolução, características e importância" explica que existem três fatores que classificam o investimento realizado como sendo de alto risco: (i) o longo prazo de duração do investimento; (ii) a assimetria informacional entre o fundo e a empresa investida; e (iii) a baixa liquidez dos ativos.

94 PAVANI, C. O Capital de Risco no Brasil: Conceito, Evolução e Perspectivas. Rio de Janeiro: E-papers, 2003. Apud In: NITA. Kleber de Freitas. O Ciclo de Investimento do Capital de Risco no Brasil e as Modalidades de Private Equity e Venture Capital. Trabalho de conclusão de curso. p. 37. Curso de Ciências Econômicas. Universidade Federal de Santa Catarina, Florianópolis. 2008. 
Os investimentos em PE/VC, como regra, têm longo prazo de duração. Normalmente, o tempo entre o aporte inicial e a saída do investimento é de 10 anos. Este período longo decorre do fato dos negócios em que os fundos estão investindo ainda estejam em uma fase incipiente ou de implantação, exigindo, por isso, um tempo razoável para serem desenvolvidos, consolidados e passarem a oferecer o retorno financeiro desejado ${ }^{95}$.

Dessa forma, o fundo não investe com a intenção de permanecer no empreendimento por tempo indeterminado, haverá um momento em que o desinvestimento será realizado, com a consequente saída do fundo.

A saída do investimento, como iremos analisar mais adiante neste trabalho, faz parte da essência desta modalidade de negócio, pois é no desinvestimento que os fundos costumam obter a maior parte dos ganhos financeiros almejados.

O segundo fator que influencia no risco dos investimentos em Venture Capital e Private Equity é a grande assimetria informacional entre o fundo investidor e a empresa investida.

Por assimetria de informações, entende-se "o conhecimento privativo, por uma das partes envolvidas em qualquer espécie de negócio, de detalhes relevantes sobre o objeto da negociação" ${ }^{\circ}$.

Mais especificamente no caso dos investimentos em PE/VC, os fundos podem não ter acesso a algumas informações, intencionalmente ou não,

95 BERNARDINO, Diogo. Fundos de Venture Capital e Private Equity: breve análise sobre sua evolução, características e importância. Revista de Direito Bancário e Mercado de Capitais, São Paulo, v. 61, p.55, jul./set. 2013. Trimestral.

96 Ibidem. 
omitidas ou até mesmo adulteradas pelas empresas investidas, que envolvam aspectos contábeis, financeiros e gerenciais da investida

Empreendedores que procuram um fundo de Venture Capital frequentemente apresentam apenas uma ideia de um plano de negócios. Alguns candidatos sequer estão neste estágio. Certamente, nem todos os projetos planejados receberão o financiamento. Por estar o projeto em um estágio inicial, a assimetria de informações entre seu fundador (empreendedor) e o financiador é extremamente alta. O proprietário conhece a qualidade do projeto, mas o fundo de Venture Capital não. ${ }^{97}$ (trad. livre)

Ainda que o processo de Due Diligence (análise das áreas da investida, receptoras de recursos) seja uma fase obrigatória do ciclo de investimento, a assimetria de informações nunca é completamente anulada ${ }^{98}$.

A combinação entre o longo prazo de duração do investimento e o alto grau de incerteza sobre um retorno financeiro positivo resulta na baixa liquidez dos títulos vinculados aos fundos.

Em geral, as empresas investidas possuem ações com liquidez pífias e por este fato o fundo precisa acompanhar o desenvolvimento da empresa durante todo o tempo que está atuando para o seu desenvolvimento, fazendo assim com que a ação tenha uma liquidez maior, a um valor atrativo para o fundo.

97 "Entrepreneurs who approach VCs are often equipped only with an idea and a business plan. Some applicants are not even at this stage. Clearly, not every planned project is worth financing. Since the venture is in such an early stage, asymmetric information between the project's founder (entrepreneur) and the financier is extremely high. The owner may know the quality of the project, but the VC does not." SCHAFER, Dorethea. How Important is the Venture Capital Industry? An Assemblent Based on a comparison of the U.S. And the German Financial Systems. p. 9. Disponível em <www.aicgs.org/site/wp-content/uploads/2011/10/schaefer.pdf> Acesso em: 25 abri. 2017.

98 SZTAJN, Rachel; AZEVEDO, Paulo Furquim de; ZYLBERSZTAJN, Décio. Economia dos contratos. In:___ _ ZYLBERSZTAJN, Décio (orgs.) Direito \& economia. Análise econômica do direito das organizações. Rio de Janeiro: Elsevier, 2005. p. 122-123. 


\section{CAPÍTULO 3. A LÓGICA DO INVESTIMENTO DE CAPITAL DE RISCO}

\subsection{Os estágios de desenvolvimento dos empreendimentos avo}

Conforme introduzido nos capítulos anteriores, os fundos de PE/VC têm como sua principal característica a possibilidade de realizar investimentos em empreendimentos que se encontram em diferentes estágios de desenvolvimento.

Isso faz com que a indústria de capital de risco seja segmentada em nichos de atuação - consequentemente, para cada estágio evolutivo do negócio, existe uma necessidade de investimento específica, e um segmento específico desta indústria especializado em suprir essa necessidade ${ }^{99}$.

Em uma fase embrionária, pré-operacional, os empreendedores necessitam de pequenos aportes, para o desenvolvimento inicial de ideias ${ }^{100}$, um plano de negócios (business plan) - que é a tradução de uma ideia na linguagem empresarial - e, em seguida, testar as ideias no mercado ou registrar uma patente. Esse pequeno aporte é chamado de "capital semente" (seed capital) ${ }^{101}$.

Em geral, a fase inicial desses empreendimentos é caracterizada por um plano de negócios e um capital inicial, oriundo das economias pessoais ou de

99 NITA. Kleber de Freitas. O Ciclo de Investimento do Capital de Risco no Brasil e as Modalidades de Private Equity e Venture Capital. Trabalho de conclusão de curso. Curso de Ciências Econômicas. Universidade Federal de Santa Catarina, Florianópolis, 2008.

100 CARVALHO, Antônio G.; RIBEIRO, Leonardo L.; FURTADO, Cláudio V. A indústria de private equity e venture capital: primeiro censo brasileiro. São Paulo: Saraiva, 2006.

101 ENEI, José Virgílio Lopes. O capital de risco e o private equity no Brasil: a nova lógica do investimento. In: ADAMEK, Marcelo Vieira Von (Coord.). Temas de direito societário $e$ empresarial contemporâneos. p. 727. São Paulo: Malheiros, 2011. 
familiares do empreendedor original, e algumas vezes de angels investors ${ }^{102}$. O aporte de capital inicial ou o segundo aporte se faz necessário, geralmente no primeiro ano de funcionamento da empresa, quando ela ainda não vende seus produtos/serviços comercialmente. Podemos chamar essa fase de start up, ou "estruturação inicial”, quando traduzida"

A segunda fase é composta por empresas que já iniciaram a contratação de profissionais e já efetuaram todos os estudos necessários para colocar em prática seu plano de negócios, mas ainda necessitam de um local adequado de trabalho, e o desenvolvimento das etapas iniciais do plano de negócios ${ }^{104}$. Ademais, o leque de fontes de capital para esses negócios não se restringe aos financiadores da fase de seed capital, mas passa a incorporar também o capital de risco, parceiros, recursos de clientes e financiamentos bancários.

São nas duas fases iniciais que as maiores taxas de mortalidade são identificadas - já que as empresas apresentam apenas despesas préoperacionais e nenhum faturamento ${ }^{105}$.

Após sobreviverem à fase inicial, com a implementação e teste do produto, mas em pequena escala, as empresas entram na fase de expansão (também chamada de fase intermediária, ou mid-stage) ${ }^{106} . \mathrm{O}$ aporte de capital se faz necessário para a expansão das atividades da empresa, que já vende seus produtos comercialmente, seja para capital de giro, expansão da planta,

102 ENEI, José Virgílio Lopes. O capital de risco e o private equity no Brasil: a nova lógica do investimento. In: ADAMEK, Marcelo Vieira Von (Coord.). Temas de direito societário e empresarial contemporâneos. p. 727. São Paulo: Malheiros, 2011.

103 NESHEIM, John. High-Tech Start Up: the Complete Handbook for Creating Successful New High Tech Companies, Nova York, The Free Pass, 2000; HARMON, Steve. Zero Gavity: Riding Venture Capital from High-Tech Start-Up to Breakout IPO, Priceton, Bloomberg Press, 1999.

104 CARVALHO, Antonio G.; RIBEIRO, Leonardo L.; FURTADO, Cláusdio V. A indústria de private equity e venture capital: primeiro censo brasileiro. São Paulo: Saraiva, 2006.

105 ENEI, José Virgílio Lopes. Op.cit.

106 Ibidem. 
da rede de distribuição ou ainda o investimento em comunicação e marketing ${ }^{107}$.

As três fases descritas acima - embrionária (seed), estruturação inicial (start-up) e expansão (mid-stage) - são o foco dos investimentos em Venture Capital $^{108}$.

Os investidores dedicados a este nicho precisam identificar algumas poucas ideias e empresas verdadeiramente promissoras dentre as centenas que lhes são apresentadas. Além disso, é necessário haver uma expertise específica para orientar empreendedores inexperientes e apoiá-los no desenvolvimento e profissionalismo de sua empresa ${ }^{109}$.

Em virtude do alto risco do investimento nessas fases de desenvolvimento, quando as empresas sobrevivem às fases iniciais, os retornos oferecidos aos investidores de Venture Capital são múltiplas vezes superiores ao capital investido ${ }^{110}$.

Após a fase intermediária de expansão, com o seu produto já testado e capaz de ser produzido ao menos numa escala modesta ou intermediária, a empresa segue para a fase de desenvolvimento avançado (late stage) quando, além do produto mais solidamente comprovado, a empresa já apresenta certo nível de lucratividade e um horizonte visível de amadurecimento e saída para o investidor de risco ${ }^{111}$.

107 CARVALHO, Antonio Gledson de; RIBEIRO, Leonardo L.; FURTADO, Cláusdio V. A indústria de private equity e venture capital: primeiro censo brasileiro. São Paulo: Saraiva, 2006. 108 Ibidem. pp. 30-31.

109 ENEI, José Virgílio Lopes. O capital de risco e o private equity no Brasil: a nova lógica do investimento. In: ADAMEK, Marcelo Vieira Von (Coord.). Temas de direito societário $e$ empresarial contemporâneos. p. 727. São Paulo: Malheiros, 2011.

110 Ibidem.

111 Ibidem. p. 728. 
No final desta fase de investimento, a empresa pode ser referida como pré-IPO (bridge finance), considerando já estar muito próxima do grau de amadurecimento necessário ao lançamento de sua oferta pública inicial de ações - IPO. O aporte é realizado quando a empresa planeja uma introdução em bolsa de valores em prazo de até dois anos, podendo envolver a reestruturação de posições acionárias de grandes acionistas ${ }^{112}$.

As fases de expansão (mid-stage) e a fase de desenvolvimento avançado (late-stage), incluindo o pré-IPO (bridge finance), são o foco principal dos investidores de Private Equity ${ }^{113}$.

Ao final de todos os estágios, quando a empresa está madura, o aporte realizado pelo mecanismo de capital de risco é substituído pela capitação de recursos do público, através da abertura do capital da sociedade investida, permanecendo todas as fontes de capital da etapa anterior ${ }^{114}$.

Outros investimentos são considerados típicos de Private Equity, ainda que não estejam diretamente relacionados com o ciclo de desenvolvimento do negócio apresentado acima. Eles ocorrem de diversas modalidades, como:

a) Financiamento de aquisições (aquisition finance): o capital é utilizado para a expansão por meio da aquisição de outras empresas;

b) Tomada de controle pelos executivos (MBO/I para management buyout/in): o capital é utilizado para financiar a equipe de gestores, da própria empresa ou externos, que objetivam adquirir o controle de uma empresa;

112 CARVALHO, Antônio Gledson de Carvalho; RIBEIRO, Leonardo de Lima; FURTADO, Cláudio Vilar. A Indústria de Private Equity e Venture Capital: Primeiro Censo Brasileiro, cit., pp. 31. 113 Ibidem.

114 NITA. Kleber de Freitas. O Ciclo de Investimento do Capital de Risco no Brasil e as Modalidades de Private Equity e Venture Capital. Trabalho de conclusão de curso. Curso de Ciências Econômicas. Universidade Federal de Santa Catarina, Florianópolis, 2008. 
c) Recuperação empresarial (turnaround): aporte feito quando a empresa se encontra em dificuldade operacional e/ou financeira e existe a aposta na recuperação;

d) Mezanino: investimentos em estágios avançados do desenvolvimento da empresa por meio de dívidas subordinadas;

e) PIPES (private equity in public equity): é um estágio à parte, representando a aquisição do capital acionário de empresas já listadas em bolsa $^{115}$.

Mesmo com a diversificação da aplicação de recursos pelos agentes de Venture Capital e de Private Equity, aportados conforme os variados estágios do ciclo de desenvolvimento das empresas, elas costumam recorrer a diferentes tipos de investidores, em diversas fases de sua expansão, ou mais comumente a subsequentes desembolsos (tranches ou rounds) à medida que determinadas metas empresariais de amadurecimento são atingidas ${ }^{116}$.

O objetivo do quadro a seguir é resumir hipoteticamente os diferentes estágios de maturidade ${ }^{117}$ de uma empresa, apresentar suas necessidades financeiras e quais segmentos da indústria de capital de risco têm uma tendência em aportar recursos em cada um dos estágios.

115 CARVALHO, Antônio Gledson de Carvalho; RIBEIRO, Leonardo de Lima; FURTADO, Cláudio Vilar. A Indústria de Private Equity e Venture Capital: Primeiro Censo Brasileiro, cit., pp. 31.

116 ENEI, José Virgílio Lopes. O capital de risco e o private equity no Brasil: a nova lógica do investimento. In: ADAMEK, Marcelo Vieira Von (Coord.). Temas de direito societário e empresarial contemporâneos. p. 729. São Paulo: Malheiros, 2011.

117 "A maturidade pode estar representada por diversos aspectos, como idade da empresa, volume de faturamento, número ou qualidade dos clientes, número ou potencial dos produtos ou outros elementos." In: NITA. Kleber de Freitas. O Ciclo de Investimento do Capital de Risco no Brasil e as Modalidades de Private Equity e Venture Capital. Trabalho de conclusão de curso. Curso de Ciências Econômicas. Universidade Federal de Santa Catarina, Florianópolis, 2008. 


\begin{tabular}{|c|c|c|c|}
\hline $\begin{array}{l}\text { Estágio de } \\
\text { desenvolvimento }\end{array}$ & $\begin{array}{l}\text { Caracteristicas e necessidades de } \\
\text { financiamento }\end{array}$ & $\begin{array}{l}\text { Modalidade de } \\
\text { Capital de } \\
\text { Risco }\end{array}$ & Investidor \\
\hline$P \& D$ & $\begin{array}{c}\text { Empresa não possui capacidade de geração } \\
\text { de receita. Financiamento é necessário para } \\
\text { cobrir gastos com pesquisa básica e } \\
\text { desenvolvimento de nova tecnologia. A } \\
\text { necessidade de capital não é grande, porém o } \\
\text { risco de o negócio não dar resultado é muito } \\
\text { grande. }\end{array}$ & \begin{tabular}{|l} 
\\
Love Money \\
Seed Capital \\
Venture Capital
\end{tabular} & $\begin{array}{l}\text { Capital próprio, } \\
\text { amigos, angels } \\
\text { investors, agências } \\
\text { públicas de } \\
\text { fomento. }\end{array}$ \\
\hline Start-up & $\begin{array}{c}\text { Nesse estágio a necessidade de capital é } \\
\text { significativa. As despesas são as de uma } \\
\text { empresa recém constituida, que precisa } \\
\text { desenvolver sua área comercial, equipe, } \\
\text { produção e ainda precisa investir muito em } \\
\text { P\&D. }\end{array}$ & $\begin{array}{l}\text { Seed Capital } \\
\text { Venture Capital }\end{array}$ & $\begin{array}{l}\text { Angels investors, } \\
\text { agências públicas } \\
\text { de fomento. }\end{array}$ \\
\hline Estágio inicial & $\begin{array}{c}\text { O produto ou o serviço desenvolvido já } \\
\text { começa a ser introduzido no mercado, ainda } \\
\text { que em bases limitadas. A expansão do } \\
\text { empreendimento exige contínuo investimento } \\
\text { - que precisa ser financiado. Nessa fase, } \\
\text { pode ocorrer alguma geração de receita, mas } \\
\text { ainda não de lucros. }\end{array}$ & Venture Capital & $\begin{array}{c}\text { Angels investors, } \\
\text { alguns grupos } \\
\text { privados. }\end{array}$ \\
\hline $\begin{array}{l}\text { Crescimento e } \\
\text { Expansão de } \\
\text { Mercado }\end{array}$ & $\begin{array}{l}\text { A empresa já ampliou as vendas e começa a } \\
\text { obter fluxo regular de receitas, o que } \\
\text { aumenta sua capacidade de financiar } \\
\text { internamente os novos investimentos. } \\
\text { Todavia, em função da magnitute dos } \\
\text { investimentos requeridos para uma rápida } \\
\text { ascenção do negócio, pode ser necessário o } \\
\text { acesso a financiamento de terceiros. }\end{array}$ & $\begin{array}{l}\text { Venture Capital } \\
\text { Private Equity }\end{array}$ & $\begin{array}{l}\text { Bancos, fundos de } \\
\text { pensão, pessoas } \\
\text { fisicas, grupos } \\
\text { privados. }\end{array}$ \\
\hline Maturidade & $\begin{array}{c}\text { A empresa se estabelece no mercado e } \\
\text { continua a gerar grandes volumes de venda, } \\
\text { ganhando economia de escala. Uma } \\
\text { expansăo relativamente menor traduz no } \\
\text { aumento do fluxo de caixa positivo. A } \\
\text { empresa torna-se lucrativa e, em alguns } \\
\text { casos, começa a se preparar para abrir capital } \\
\text { no mercado acionário, através de uma oferta } \\
\text { pública inicial (IPO) }\end{array}$ & Private Equity & $\begin{array}{l}\text { Bancos, fundos de } \\
\text { pensão, pessoas } \\
\text { fisicas, grupos } \\
\text { privados. }\end{array}$ \\
\hline Consolidação & $\begin{array}{l}\text { Empresa e produtos já consolidados no } \\
\text { mercado, com fator de risco para obtensão de } \\
\text { recursos muito menor, uma vez que não há } \\
\text { mais grandes incertezas em relação ao } \\
\text { mercado de atuação desta. }\end{array}$ & $\begin{array}{l}\text { Mercado de } \\
\text { capitais }\end{array}$ & $\begin{array}{l}\text { Todos. Desde } \\
\text { pessoa fisica com } \\
\text { poucos recursos } \\
\text { até fundos de } \\
\text { investimento } \\
\text { bilionários. }\end{array}$ \\
\hline
\end{tabular}

Fonte: Ribeiro (2005) ${ }^{118}$

A maturidade advém, portanto, de conhecimento e capital necessário para administrar a ideia do plano pré-estabelecido entre os agentes, resultando na consolidação no mercado e a uma necessária forma de se realizar o desinvestimento.

118 RIBEIRO, Leonardo de Lima. O modelo brasileiro de private equity e venture capital. Dissertação de Mestrado. Programa de pós-graduação em Administração, Universidade de São Paulo, São Paulo, 2005. 


\subsection{0 ciclo de investimento no capital de risco}

O ciclo do investimento de um gestor pode ser dividido em oito fases: (a) Captação de recursos; (b) Originação e seleção de investimentos; (c) Análise e avaliação; (d) Auditoria ou Due Diligence; (e) Negociação e estruturação do investimento; (f) Conclusão do negócio e aporte do capital; (g) Monitoramento; e (h) Saída/Desinvestimento ${ }^{119}$ - conforme brevemente explicado abaixo:

(a) Captação de recursos: Os gestores dos fundos saem em busca de investidores. Neste momento, a credibilidade dos gestores é peça fundamental para a captação de investidores ser bem sucedida ${ }^{120}$;

(b) Originação e seleção de investimentos: Ocorre a seleção empresas e projetos. Além de trabalhar de forma ativa na procura de bons projetos, os gestores também recebem propostas de empresas e empreendedores buscando investimentos ${ }^{121}$;

(c) Análise e avaliação: Os gestores irão analisar o negócio no qual pretendem investir os recursos captado dos investidores. Essa etapa costuma ser baseada em um Acordo de Confidencialidade, prevenindo o não vazamento de dados obtidos na empresa e no próprio mercado. Nela, há uma análise detalhada do histórico da empresa, do próprio empreendedor, da integridade das informações prestadas no plano de negócios em questão, assim como uma pesquisa acerca dos clientes atuais e potenciais, fornecedores, especialistas no setor em que a empresa atua e até empreendedores que já fazem parte do portfólio do gestor para verificar a percepção de qualidade e de valor do produto/serviço. É nesta etapa que o

119 NITA. Kleber de Freitas. O Ciclo de Investimento do Capital de Risco no Brasil $e$ as Modalidades de Private Equity e Venture Capital. Trabalho de conclusão de curso. Curso de Ciências Econômicas. Universidade Federal de Santa Catarina, Florianópolis, 2008.

120 Ibidem.

121 Ibidem. 
fator risco começa a ser analisado pelo gestor, a fim de verificar a viabilidade da operação (projeções do fluxo de caixa para um período de três a dez anos, estimando-se o valor presente da empresa, ajustado ao risco da operação) ${ }^{122}$.

(d) Due Diligence: Essa etapa apenas inicia se o investimento for considerado viável pelo gestor e se os empreendedores concordarem em realizar a operação. Inicia-se um processo de avaliação extremamente cauteloso, baseado na auditoria fiscal, contábil e jurídica da empresa. Essa etapa ocorre antes mesmo das negociações acerca do valor da empresa, chamado de valuation, uma vez que, muitas vezes, as informações encontradas nela, influenciarão no valor final determinado no valuation ${ }^{123}$.

(e) Negociação e estruturação do investimento: Essa etapa determina o valor atribuído à empresa (valuation). Procura-se saber o potencial do empreendimento para então aplicar a tese de investimento e a estratégia que será realizada naquela empresa. É um dos passos mais importantes de todo o processo, e por isso, esta fase costuma ser motivo de atrito entre os gestores de capital de risco e os empreendedores.

As principais abordagens, usualmente utilizadas para a valoração do volume financeiro a ser investido são fluxos de caixa descontados e avalição por múltiplo de mercado, sendo muito comum que os dois métodos sejam utilizados simultaneamente, para afinar a percepção de valor do negócio ${ }^{124}$. Dentre outros fatores, são incorporados ao valor da avaliação (i) os ativos intangíveis; (ii) os fatores de risco envolvidos no investimento.

122 NITA. Kleber de Freitas. O Ciclo de Investimento do Capital de Risco no Brasil e as Modalidades de Private Equity e Venture Capital. Trabalho de conclusão de curso. Curso de Ciências Econômicas. Universidade Federal de Santa Catarina, Florianópolis, 2008.

123 Ibidem.

124 Ibidem. 
O empreendimento cujos ativos são intangíveis são de difícil mensuração. Dentre os principais ativos intangíveis destaca-se: os direitos de propriedade intelectual, a tecnologia, capital humano, capital relacional (base de clientes e reputação) e capital organizacional (capacidade inovadora, processos internos e modelo de negócios) ${ }^{125}$.

Ademais, outros fatores são incorporados na análise do risco do investimento, tais como, o risco tecnológico: quanto mais inovadora for a tecnologia, mais difícil fica para avaliar o seu real potencial no mercado; o risco no modelo de negócios: mudanças na empresa, no mercado e nos clientes pode inviabilizar o modelo atual de negócio; o risco de gestão: no momento de ajustar a governança corporativa da empresa, os gestores precisam alterar a equipe de gestão, podendo causar grandes prejuízos para a empresa se esta não estiver preparada e o processo não for bem administrado; o risco da saída: tendo em vista que as saídas mais rentáveis ocorrem por meio de IPO e venda estratégica - conforme será exposto no próximo capítulo, o risco de saída é o risco de o ativo não encontrar interessados devido a condições adversas de mercado, o que seria um sério problema para obter-se retorno aos investidores; há ainda o risco de diversificação do portfólio de empresas investidas, e o risco de o mercado não compreender às expectativas ou se tornar adverso por algum motivo ${ }^{126}$.

Após executado o valuation da empresa, diferentes abordagens são seguidas para chegar-se ao valor de investimento e percentual de participação acionária, dependendo do setor, dos riscos envolvidos e da fase de maturidade em que se encontra o empreendimento.

125 RIBEIRO, Leonardo de Lima; TIRONI, L. F. Ativos Intangíveis: Avaliação e Mensuração no Contexto de Private Equity e Venture Capital. Brasília: IPEA, 2007.

126 NITA. Kleber de Freitas. O Ciclo de Investimento do Capital de Risco no Brasil e as Modalidades de Private Equity e Venture Capital. Trabalho de conclusão de curso. Curso de Ciências Econômicas. Universidade Federal de Santa Catarina, Florianópolis, 2008. 
Durante a negociação, discute-se a participação acionária do fundo, o grau de participação na gestão da empresa, assim como a eventual necessidade de reestruturação ou, ainda, mecanismos de controle que o fundo investidor pode requerer. Nos estágios mais avançados da negociação, ocorre o detalhamento da estrutura financeira e legal - através do acordo de acionistas, que regerá como o fundo participará do desenvolvimento do projeto, bem como, alguns mecanismos que evidenciam como será a política de governança corporativa aplicada ao caso específico ${ }^{127}$. Ademais, os acordos de acionistas, quando elaborados no contexto do capital de risco, tendem a abordar mecanismos de mitigação de possíveis conflitos ${ }^{128}$, uma vez que a intenção é manter um ambiente equilibrado entre o gestor e o empreendedor, como uma verdadeira parceria, possibilitando assim um melhor monitoramento do empreendimento.

(f) Conclusão do negócio e aporte do capital: conforme detalhadamente descrito neste trabalho, a entrada do capital dos fundos de PE/VC é feita através da emissão de ações, quotas de participação, debêntures conversíveis, opções, bônus de subscrição ou warrants. A utilização do capital é feita de diversas formas, a depender da fase de desenvolvimento do negócio, ou seja, das suas necessidades naquele momento.

(g) Monitoramento: Nessa fase o fundo monitorará - participando ativamente - a utilização do investimento, para assim, gerenciar o risco e obter o seu resultado financeiro. A forma mais conhecida de promover a

127 NITA. Kleber de Freitas. O Ciclo de Investimento do Capital de Risco no Brasil e as Modalidades de Private Equity e Venture Capital. Trabalho de conclusão de curso. Curso de Ciências Econômicas. Universidade Federal de Santa Catarina, Florianópolis, 2008.

128 NETO, Mario Casale. Um estudo sobre a indústria de capital de risco com foco em pequenas e médicas empresas brasileiras. Trabalho de conclusão de curso. Curso de Engenharia de Produção Mecânica, Universidade de São Paulo, São Carlos, 2007. 
comunhão de interesses entre o fundo e os executivos da empresa é atrelar a sua remuneração ao desempenho dos negócios ${ }^{129}$.

(h) Saída/Desinvestimento: Após o período de médio/longo prazo, muitas vezes pré-determinado no contrato, há a "saída" do investimento, que pode ser feita de diversas formas - que será melhor abordado no próximo capítulo.

$\mathrm{Na}$ avaliação feita pelos especialistas em $\mathrm{PE} / \mathrm{VC}$, normalmente, são observados, dentre outros detalhes: (i) a qualidade e o profissionalismo da atual gestão, sobretudo no tocante às práticas de governança; (ii) o potencial do produto ou serviço disponibilizado, atentando para itens como: poder de negociação dos clientes e dos fornecedores, as possíveis vedações ou restrições legais etc.; e (iii) o equilíbrio financeiro das operações (se o produto é viável do ponto de vista financeiro e o operacional ${ }^{130}$.

129 NITA. Kleber de Freitas. O Ciclo de Investimento do Capital de Risco no Brasil e as Modalidades de Private Equity e Venture Capital. Trabalho de conclusão de curso. Curso de Ciências Econômicas. Universidade Federal de Santa Catarina, Florianópolis, 2008.

130 BERNARDINO, Diogo. Fundos de Venture Capital e Private Equity: breve análise sobre sua evolução, características e importância. Revista de Direito Bancário e Mercado de Capitais, São Paulo, v. 61, p.59, jul./set. 2013. Trimestral. 


\section{CAPÍTULO 4. O DESINVESTIMENTO}

Há autores que defendem que o principal papel do investimento de risco é a busca de oportunidades de investimento e o efetivo monitoramento dos empreendedores ${ }^{131}$. Por outro lado, outros defendem que o negócio para os fundos de capital de risco seja investir por um período de tempo e sair no momento adequado, quando os gestores são finalmente recompensados financeiramente pelo resultado obtido ${ }^{132}$. Sob essa última perspectiva, a saída acaba dominando a forma com que outras atividades, no ciclo de investimento, são realizadas ${ }^{133}$.

\subsection{Estratégias de Saída do Investimento}

Sob o ângulo contratual, a relação entre o veículo captador e concentrador dos recursos dos investidores, representado pelo administrador, e do outro lado, as empresas investidas e os empreendedores, é usualmente consumada por meio de um instrumento contratual de subscrição de ações.

É através deste instrumento contratual que são estabelecidas (i) as condições pelas quais a sociedade investida emitirá novas ações e os empreendedores originais renunciarão ou cederão seu direito de preferência em favor do veículo investidor, para que este realize o novo investimento; (ii) as condições suspensivas do negócio como um todo; (iii) o preço de emissão, o prazo e as condições de integralização; (iv) as declarações e garantias prestadas pela sociedade investida ou pelos empreendedores originais em favor do novo investidor; (v) as indenizações ou multas

131 SAHLMAN, W.A. The structure and governance of venture capital organizations. Jornal of Financial Economics, Rochester, v.27, n.2, p.473-521, Sept. 1990.

132 GLADSTONE, D. Venture capital handbook. Englewood Cliffs, NJ: Prentice Hall, 1998. p.215233.

133 RIBEIRO, Leonardo de Lima; ALMEIDA, Martinho Isnard Ribeiro de. Estratégia de saída em capital de risco. R.Adm., São Paulo, v.40, n.1, p.55-67, jan./fev./mar. 2005. 
aplicáveis na hipótese de violação de tais declarações, e garantias e outras obrigações contratuais ${ }^{134}$.

Devido à complexidade e lógica dos investimentos de $\mathrm{PE} / \mathrm{VC}$, nós podemos compreender porque essa relação não é regulada apenas por este instrumento contratual de subscrição de novas ações da sociedade investida. Para fins de concretização da fase de monitoramento no ciclo do investimento, o gestor do veículo de PE/VC precisará participar da sua gestão e se relacionar com os empreendedores originais.

Sendo assim, concomitantemente à elaboração do instrumento contratual que disciplinará a venda da participação acionária da sociedade investida ao veículo de PE/VC, necessariamente, haverá a negociação de um acordo de acionistas - celebrado entre, de um lado os empreendedores originais, e do outro lado, o veículo investidor de PE/VC, e como interveniente anuente, a sociedade investida.

O acordo de acionistas disciplinará os direitos e obrigações do novo investidor em relação aos sócios originais, incluindo quóruns especiais e direito de veto no âmbito da assembleia de acionistas ou do conselho de administração, nomeação de conselheiros e diretores, compromissos de não competição, restrições à transferência de ações e mecanismos de soluções de disputas - dentre outras cláusulas típicas desse instrumento contratual ${ }^{135}$.

A lógica contratual apresentada acima, até o momento, não difere das demais operações usuais de fusão e aquisição de empresas, em que o comprador e vendedor permanecem sócios do negócio. O investimento de $\mathrm{PE} / \mathrm{VC}$ inova e rompe com a lógica contratual tradicional de fusões e

134 ENEI, José Virgílio Lopes. O capital de risco e o private equity no Brasil: a nova lógica do investimento. In: ADAMEK, Marcelo Vieira Von (Coord.). Temas de direito societário e empresarial contemporâneos. p. 732. São Paulo: Malheiros, 2011.

135 Ibidem. 
aquisições no que tange ao aspecto temporal do investimento e sua liquidação ${ }^{136}$.

Em regra, as empresas se unem com um ânimo de longo prazo ou indeterminado, quando não permanente, ainda que surjam crises ou desligamentos no futuro, quebrando a expectativa do longo prazo. No entanto, salvo raríssima exceções, as empresas não se fundem, tampouco adquirem ou incorporam umas às outras, já com a intenção de se separarem em prazo determinado ${ }^{137}$.

Nos investimentos de $\mathrm{PE} / \mathrm{VC}$, os investimentos acionários são realizados com a perspectiva de que precisarão ser liquidados em um prazo máximo de 3 a 10 anos. Isso ocorre para que o capital originalmente investido e os ganhos dele derivados possam ser devolvidos ao veículo investidor e deste aos investidores no ápice da cadeia financeira, o investimento precisa ser liquidado.

O gestor de PE/VC deve analisar qual é o melhor momento para realizar o desinvestimento, e se retirar da sociedade investida, vez que, este é o momento mais importante para os investidores do veículo de PE/VC, quando os fundos costumam obter a maior parte dos ganhos financeiros almejados.

Idealmente, o prazo para o desinvestimento ocorrer coincide com o período de amadurecimento da empresa, quando é possível realizar a venda de ações no mercado de capitais por meio da oferta pública inicial de ações (Initial Public Offering ou IPO).

136 ENEI, José Virgílio Lopes. O capital de risco e o private equity no Brasil: a nova lógica do investimento. In: ADAMEK, Marcelo Vieira Von (Coord.). Temas de direito societário e empresarial contemporâneos. p. 732. São Paulo: Malheiros, 2011.

137 Ibidem. 
No IPO, o investimento pode ser liquidado por meio da venda da participação acionária correspondente (a parcela secundária) para terceiros, em conjunto com a emissão de novas ações (parcela primária), no processo de oferta pública, com a criação de valor (prêmio) que esse marco usualmente oferece $^{138}$.

Segundo Schwienbacher ${ }^{139}$, esta forma de saída é atraente para empreendedores originários que desejam manter o controle da empresa após a saída do veículo de $\mathrm{PE} / \mathrm{VC}$ e ao mesmo tempo não acham que outra estratégia de saída seja mais adequada.

É o momento que ocorre a maximização dos ganhos do fundo de $\mathrm{PE} / \mathrm{VC}$, e consequentemente, dos investidores e do gestor, além de beneficiar a empresa em si, que passa a ter mais opções de investimentos, agora com acesso ao investimento do público em geral. Ademais, pode haver ganhos de reputação para o gestor do PE/VC se o IPO for um sucesso. Os ganhos em termos de reputação são importantes para fundos jovens que querem, através da criação de um histórico de funcionamento de sucesso, atrair novos recursos para seus fundos ${ }^{140}$.

Um mercado de capitais eficiente e ativo, que permita a saída dos investidores de capital de risco através da abertura do capital é crítico para a

138 ENEI, José Virgílio Lopes. O capital de risco e o private equity no Brasil: a nova lógica do investimento. In: ADAMEK, Marcelo Vieira Von (Coord.). Temas de direito societário e empresarial contemporâneos. p. 733. São Paulo: Malheiros, 2011.

139 SCHWIENBACHER, A. An Empirical Analysis of Venture Capital Exits in Europe and in the United States. Berkeley, CA.: University of California, 2002a.

140 RIBEIRO, Leonardo de Lima; ALMEIDA, Martinho Isnard Ribeiro de. Predominância da "venda estratégica" nas estratégias de saída de capital de risco no Brasil: Uma pesquisa empírica. Faculdade de Economia, Administração e Contabilidade da Universidade de São Paulo. Departamento de Administração. Artigo submetido ao VI Semead, agosto 2004. 
própria existência de um mercado ativo e eficiente de capital de risco ${ }^{141}$. Mercados de ação ilíquidos trazem maiores riscos para saídas por IPO ${ }^{142}$.

No Brasil, a bolsa de valores de São Paulo (BM\&FBovespa) possui quatro segmentos de listagem de ações em bolsa de valores: o segmento tradicional, o Nível 1, o Nível 2 e o Novo Mercado. Os três últimos segmentos, criados em 2000 com o objetivo de atrair um maior número de investidores para o mercado de capitais, exigem observância de práticas de governança corporativa mais abrangentes em relação àquelas estabelecidas por $l \mathrm{ei}^{143}$.

No entanto, a BM\&FBovespa, a partir de 2005, dispõe de outra opção menos conhecida para companhias interessadas em abrir o seu capital. O segmento especial de listagem no mercado de balcão organizado, o BOVESPA MAIS, é direcionado às pequenas e médias empresas, e pode ser visto como uma alternativa menos custosa de desinvestimento para os empreendimentos objeto de investimentos de $\mathrm{PE} / \mathrm{VC}^{144}$.

141 BLACK, B.; GILSON, R. Venture Capital and the Structure of Capital Markets: Banks versus Stock Markets. Journal of Financial Economics, n.47, p.243-277, 1998.

142 SCHWIENBACHER, A. An Empirical Analysis of Venture Capital Exits in Europe and in the United States. Berkeley, CA.: University of California, 2002a.

143 PENNA, Paulo Eduardo; REIS. André Provedel. O BOVESPA MAIS como alternativa de saída em investimentos de private equity, publicado no website da Associação Brasileira de Private Equity e Venture Capital - ABVCAP em setembro de 2013. Disponível em: < http://www.loboeibeas.com.br/archives/3488 >. Acesso em: 15 maio. 2017.

144 O novo segmento concede entre outros benefícios: (i) o prazo de 7 anos para as companhias atingirem condições mínimas de liquidez de suas ações, ou para atingir o percentual mínimo do free float (volumes de papéis em circulação), que em regra é de $25 \%$ do capital no Novo Mercado e nos Níveis 1 e 2 da BM\&FBovespa; (ii) isenção da taxa de registro como companhia aberta e um desconto gradual na taxa de manutenção da listagem (100\% no primeiro ano, gradualmente reduzida para $25 \%$ no quarto ano). Consequentemente, os custos são menores àqueles suportados por companhias vinculadas aos demais segmentos da listagem da BM\&FBovespa. Em contrapartida, as companhias listadas no BOVESPA MAIS estão obrigadas a adotar práticas que garantam um elevado nível de transparência e um maior alinhamento entre os interesses dos acionistas majoritários e minoritários. Além disso, dentre as várias práticas de governança corporativa, destacase as seguintes: (i) a companhia só pode emitir ações ordinárias (as ações preferenciais apenas são permitidas se tiverem sido emitidas antes da sua adesão ao BOVESPA MAIS); (ii) na hipótese de alienação do controle, os minoritários são incluídos na oferta apresentada aos controladores pelo eventual adquirente; e (iii) as disputas entre acionistas, administradores da companhia devem ser dirimidas por arbitragem, de acordo com as regras da Câmara de Arbitragem do Mercado. In__PENNA, Paulo Eduardo; REIS. André Provedel. O BOVESPA MAIS como alternativa de saída em investimentos de private equity, publicado no website da Associação Brasileira de Private 
Ofuscado pelo Novo Mercado, a BOVESPA MAIS ainda não conseguiu obter o mesmo sucesso do seu modelo inspirador, o londrino AIM, que, lançado em 1995, rapidamente atraiu a atenção do mercado e atualmente conta com mais de três mil companhias abertas. No entanto, embora o BOVESPA MAIS, ainda seja incipiente, gestores dos fundos de PE/VC deveriam tê-lo em mente ao estruturar as alternativas de saída para seus investimentos ${ }^{145}$.

Aparentemente, existe uma crença que permeia tanto mundo acadêmico quanto o meio profissionais que o IPO é o mecanismo mais lucrativo e aquele que traz os maiores benefícios em termos de reputação ${ }^{146}$. Isso por duas razões: primeiro, porque a abertura de capital, em regra, vem acompanhada da valorização das ações da companhia, o que consubstancia uma das metas dos fundos de PE/VC. Segundo, porque liberta a companhia dos altos custos dos empréstimos bancários, abrindo outras vias de captação de recursos, via emissões de novas ações ou via emissão de debêntures no mercado público ${ }^{147}$.

No entanto, além da alternativa do IPO, a liquidação do investimento pode dar-se mediante (i) a entrada de investidores estratégicos, isto é, outras empresas interessadas em obter sinergia entre seus ativos atuais e posicionamento estratégico no mercado com a empresa adquirida. Essa operação é chamada de "saída estratégica" ou ainda trade-sale; (ii) a venda para outros investidores financeiros, que desejem diversificar seus

Equity e Venture Capital - ABVCAP em setembro de 2013. Disponível em: < http://www.loboeibeas.com.br/archives/3488 >. Acesso em: 15 maio. 2017.

145 PENNA, Paulo Eduardo; REIS. André Provedel. O BOVESPA MAIS como alternativa de saída em investimentos de private equity, publicado no website da Associação Brasileira de Private Equity e Venture Capital - ABVCAP em setembro de 2013. Disponível em: < http://www.loboeibeas.com.br/archives/3488 >. Acesso em: 15 maio. 2017.

146 SCHWIENBACHER, A. An Empirical Analysis of Venture Capital Exits in Europe and in the United States. Berkeley, CA.: University of California, 2002a.

147 BORBA, Rodrigo Rabelo Tavares. Mecanismos contratuais de liquidez nos acordos de acionistas: Da estrutura à função. Dissertação de Mestrado. Programa de pós-graduação em Direito, Universidade do Estado do Rio de Janeiro, Área de concentração: Direito Civil. Rio de Janeiro, 2016. 
investimentos; (iii) a liquidação dos títulos ou a recompra das ações pelos acionistas fundadores ${ }^{148}$; ou, ainda, (iv) a liquidação da empresa investida, que é o caso de insucesso total.

Na venda estratégica (trade-sale), a totalidade das ações é oferecida a um comprador, em geral, uma grande empresa ou grupo com atividade semelhante ou complementar à do empreendimento em questão. Na maioria das vezes, o comprador já se relacionava contratualmente com a empresa adquirida e busca atingir objetivos estratégicos, como a entrada em um novo mercado $^{149}$.

A grande vantagem do trade-sale frente aos outros mecanismos é a baixa exposição à volatilidade de mercados financeiros ${ }^{150}$. Mesmo em momentos de crise econômica, algumas empresas mantêm a capacidade de realizar aquisições ou, justamente devido ao relativo barateamento de ativos que ocorre durante uma crise, podem realizar aquisições a valores tidos como vantajosos. Segundo essa constatação, trade-sales serão preferíveis quanto maior for a volatilidade do mercado em questão ${ }^{151}$.

No caso das vendas para outros investidores, também chamada de secondary sale, as ações detidas pelo fundo de capital de risco são vendidas a um terceiro investidor. Há diversos motivos para essa estratégia ser escolhida, dentre eles o fato do negócio ter atingido uma determinada fase de desenvolvimento que o fundo de Venture Capital não agrega tanto valor e o empreendimento deve ser vendido para um fundo de Private Equity ou

148 NITA. Kleber de Freitas. O Ciclo de Investimento do Capital de Risco no Brasil e as Modalidades de Private Equity e Venture Capital. Trabalho de conclusão de curso. Curso de Ciências Econômicas. Universidade Federal de Santa Catarina, Florianópolis, 2008.

149 RIBEIRO, Leonardo de Lima; ALMEIDA, Martinho Isnard Ribeiro de. Estratégia de saída em capital de risco. R.Adm., São Paulo, v.40, n.1, p.55-67, jan./fev./mar. 2005.

150 SCHWIENBACHER, A. An empirical analysis of venture capital exits in Europe and in the United States. Berkeley: University of California, 2002.

151 RIBEIRO, Leonardo de Lima; ALMEIDA, Martinho Isnard Ribeiro de. Op.cit. 
mesmo para pessoas físicas que continuarão a investir na empresa alvo ${ }^{152}$. Além disso, essa estratégia comporta a possibilidade de o adquirente já possuir participação na empresa, adquirida da carteira do PE/VC. Essa participação anterior é vista como uma opção de compra, para o caso de a empresa-alvo mostrar-se de interesse no futuro ${ }^{153}$.

Na recompra, o empreendedor, a empresa ou os gestores da empresa (Management Buy-out - MBO) adquirem a participação detida pelo fundo de PE/VC. Este instrumento é mais raro, pois o comprador necessita de um montante elevado de recursos para conseguir recomprar as ações detidas pelo veículo de PE/VC com o lucro que o último espera obter. Muitas vezes os instrumentos contratuais dão preferência de compra aos sócios fundadores, caso o fundo PE/VC não consiga efetuar outra forma de saída preferível.

Como iremos abordar no próximo tópico, essa estratégia normalmente é acompanhada por mecanismos no acordo de acionistas que possibilitam a sua execução - na forma de opções de compra ( call) com preço de exercício pré-estabelecido por fórmulas de precificação. Em geral, o veículo de PE/VC também podem deter opções de venda ( $p u t)$ que obrigariam o empreendedor a adquirir ações do PE/VC por preços calculados por fórmulas semelhantes ${ }^{154}$. Esse mecanismo permanece como uma alternativa à liquidação total dos ativos.

A última alternativa para a saída do PE/VC é a desconstituição da empresa investida, e todos os ativos são liquidados e divididos entre os

152 RIBEIRO, Leonardo de Lima; ALMEIDA, Martinho Isnard Ribeiro de. Predominância da "venda estratégica" nas estratégias de saida de capital de risco no Brasil: Uma pesquisa empírica. Faculdade de Economia, Administração e Contabilidade da Universidade de São Paulo. Departamento de Administração. Artigo submetido ao VI Semead, agosto 2004.

153 CUMMING, D.; MAcINTOSH, J. A cross-country comparison of full and partial venture capital exits. Journal of Banking \& Finance, Roma, v.27, n.3, p.511-548, Mar. 2003.

154 RIBEIRO, Leonardo de Lima; ALMEIDA, Martinho Isnard Ribeiro de. Predominância da "venda estratégica" nas estratégias de saída de capital de risco no Brasil: Uma pesquisa empírica. Faculdade de Economia, Administração e Contabilidade da Universidade de São Paulo. Departamento de Administração. Artigo submetido ao VI Semead, agosto 2004. 
acionistas e credores. A liquidação representa insucesso do investimento em termos de geração de retornos ${ }^{155}$. Isso ocorre quando o negócio não decola, pois não conseguiu penetrar no mercado, ou por deficiência gerencial ou outros motivos. Eventualmente, o veículo de PE/VC pode liquidar uma empresa living-dead (morta-viva) ${ }^{156}$ - são empresas que ainda não perderam seus gestores e, embora economicamente viáveis, não possuem expectativa de crescimento que cobriria o custo de oportunidade do capital do tipo $\mathrm{PE} / \mathrm{VC}{ }^{157}$.

Conforme sugerem Cumming e MacIntosh ${ }^{158}$, as saídas podem ocorrer de forma total ou parcial. A extensão da saída seria proporcional à assimetria informacional. Saídas parciais são indicadores de qualidade do empreendimento. Ainda, a utilização de saídas parciais também pode ser utilizadas pelos fundos de $\mathrm{PE} / \mathrm{VC}$ jovens, que pretendem criar um histórico de sucesso para trais mais investimentos enquanto mantém participação em empreendimentos de alto potencial ${ }^{159}$.

Ademais, as estratégias são formuladas de acordo com o ambiente em que a organização está inserida. Leonardo de Lima Ribeiro e Martinho Isnard Ribeiro de Almeida destacam, em "Estratégia de saída em capital de risco"160, que como o Brasil tem características distintas de outros países - taxa de juros elevada, regulamentações específicas, uma bolsa de valores ainda pouco

155 RIBEIRO, Leonardo de Lima; ALMEIDA, Martinho Isnard Ribeiro de. Predominância da "venda estratégica" nas estratégias de saída de capital de risco no Brasil: Uma pesquisa empírica. Faculdade de Economia, Administração e Contabilidade da Universidade de São Paulo. Departamento de Administração. Artigo submetido ao VI Semead, agosto 2004.

156 RUHNKA, J.; FELDMAN, H.; DEAN, T. The "living dead" phenomena in venture capital investments. Journal of Business Venturing, v.7, n.2, p.137-155, Mar. 1992

157 RIBEIRO, Leonardo de Lima; ALMEIDA, Martinho Isnard Ribeiro de. Estratégia de saída em capital de risco. R.Adm., São Paulo, v.40, n.1, p.55-67, jan./fev./mar. 2005.

158 CUMMING, D.; MACINTOSH, J. A Cross-Country Comparison of Full and Partial Venture Capital Exit Strategies, Faculty of Law. Toronto: University of Toronto, 2000, 2002.

159 RIBEIRO, Leonardo de Lima; ALMEIDA, Martinho Isnard Ribeiro de. Predominância da "venda estratégica" nas estratégias de saida de capital de risco no Brasil: Uma pesquisa empírica. Faculdade de Economia, Administração e Contabilidade da Universidade de São Paulo. Departamento de Administração. Artigo submetido ao VI Semead, agosto 2004.

160 RIBEIRO, Leonardo de Lima; ALMEIDA, Martinho Isnard Ribeiro de. Estratégia de saída em capital de risco. R.Adm., São Paulo, v.40, n.1, p.55-67, jan./fev./mar. 2005. 
expressiva e movimentos de consolidação em diversos mercados consequentemente, a empresa de capital de risco aqui inserida deve considerar essas particularidades no momento de escolha da melhor estratégia.

Estudos empíricos demonstram a preferência do mercado brasileiro por um comportamento altamente planejador que, em geral, adota a estratégia de saída por venda estratégica. Por outro lado, existem indícios de que uma conjuntura especialmente favorável, na data em que o fundo de PE/VC inicia a construção de sua carteira de investimentos, pode influenciar a preferência pela abertura de capital (IPO). Em todos os casos, constata-se que a estratégia adotada influencia todas as etapas do ciclo de investimento de capital de risco, inclusive a decisão de investirir1 ${ }^{16}$

Notou-se que, há uma grande parte dos investidores que analisam as estratégias de saída antes mesmo de investir, comprovando a influência da saída até na atividade inicial do ciclo de investimento: seleção de investimentos. Essa influência também é percebida na fase de monitoramento, fazendo com que o gestor do veículo de PE/VC queira atrair compradores por meio de modificações nas empresas investidas. Isso pode gerar conflitos entre os sócios do negócio, que se opõe à realização do IPO, por exemplo, ou ainda, fazer com que os administradores se sintam repelidos pela possibilidade de, após uma venda estratégica, voltarem a ocupar cargo de subordinação dentro de um grande grupo empresarial ${ }^{162}$.

Ademais, a escolha do mecanismo de saída influencia diretamente no detalhamento da estrutura financeira e legal do investimento, ainda na fase de negociação e estruturação do ciclo de investimento, afetando a elaboração do contrato de subscrição de ações e do acordo de acionistas. 
Com efeito, e sem prejuízo das outras disposições tipicamente negociadas por tais investidores, seus contratos precisam prever "mecanismos de saída", isto é, cláusulas e disposições que agreguem maior liquidez ao investimento, possibilitando o desinvestimento em condições financeiramente satisfatórias para os veículos de PE/VC. Alguns desses mecanismos estão descritos no próximo item.

\subsection{Mecanismos Contratuais de Liquidez}

Como já abordado neste trabalho, os veículos de $\mathrm{PE} / \mathrm{VC}$ têm um prazo limitado para investir na empresa alvo, havendo um prazo para o investimento, um para a manutenção do investimento, e outro para o desinvestimento. Os fundos de PE/VC capitam recursos do público investidor em troca de uma promessa de rentabilidade (benchmark). Embora essa promessa de rentabilidade seja uma obrigação de meio, e não uma obrigação de resultado, o mercado sobrevive da credibilidade que os investidores têm no gestor do fundo, e na sua capacidade de gerar valor ao capital investido ${ }^{163}$.

Como todo investimento, também no capital de risco, há a necessidade de haver liquidez para ele ser realizado. Caso não haja previsão de saída, consequentemente, não se prospectam alternativas lucrativas para o desinvestimento, e o investimento não se realizará por completo.

Dessa forma, o momento da saída é fator fundamental para a realização do investimento. Ele é calculado antes mesmo do fundo de PE/VC entrar no

163 BORBA, Rodrigo Rabelo Tavares. Mecanismos contratuais de liquidez nos acordos de acionistas: Da estrutura à função. Dissertação de Mestrado. Programa de pós-graduação em Direito, Universidade do Estado do Rio de Janeiro, Área de concentração: Direito Civil. Rio de Janeiro, 2016. 
negócio - na fase do ciclo de investimento chamada de "negociação e estruturação do investimento", conforme detalhado no item anterior.

Com efeito, os respectivos acordos de acionistas precisam prever cláusulas e disposições que agreguem maior liquidez ao investimento, os chamados "mecanismos de saída" ou ainda "mecanismos de liquidez", possibilitando que o desinvestimento ocorra em condições financeiramente satisfatórias para os veículos de PE/VC.

Rodrigo Tavares Borba, destaca em sua tese de mestrado "Mecanismos contratuais de liquidez nos acordos de acionistas: Da estrutura à função"164 que a razão determinante de se estipularem mecanismos de liquidez, deriva do fato de que, sem eles, caso algum sócio deseje ou precise sair da companhia, o único e equivocado caminho, na hipótese de desavença entre as partes, seria o pedido judicial de dissolução parcial da sociedade. Embora o Supremo Tribunal de Justiça venha acolhendo tais pedidos, essa solução é desastrosa do ponto de vista econômico, na medida em que tais processos perduram por anos e, usualmente, há desavenças insolúveis em termos de valor da companhia. Tais disputas, em regra, acabam por desestabilizar a companhia, levando-a em último caso, à falência.

Isso se dá, pois, em regra, salvo nas hipóteses de direito de recesso, o sócio não pode se retirar de uma sociedade de responsabilidade limitada (LTDA. e S.A.) a seu bel-prazer, levando consigo os recursos que aportou no capital social. O caráter repentino da saída de um sócio nessas condições, pode desestabilizar a saúde financeira da sociedade, gerando até uma situação de insolvência. Por tais razões, mostra-se fundamental que os sócios pactuem mecanismos de liquidez seguros e previsíveis, nos quais seja preservado o patrimônio social. 
A previsão dos mecanismos de liquidez visa, assim, a evitar ações judiciais de dissolução parcial de sociedade, na medida em que os próprios sócios já preveriam, desde a largada, como se daria o desinvestimento societário. O objetivo deste item é analisar os diversos mecanismos de liquidez utilizado pelo mercado, apresentando suas vantagens, desvantagens e riscos.

Dentre os mecanismos de liquidez mais relevantes, está a opção de venda compulsória das ações (put option) do fundo de PE/VC para o empreendedor originário da companhia. Como analisa Gustavo Tepedino, em parecer no qual analisa a ruptura da afectio societattis e seus efeitos na put option ${ }^{165}$ :

[...] para os sócios minoritários, postos em situação de manifesta desvantagem na condução da companhia, a preservação do acordo significa, as mais das vezes, a preservação do próprio investimento, servindo, portanto, de elemento essencial para a expressão do valor social da livre iniciativa (art. $1^{\circ}, \mathrm{IV}$, da CF/1998) e do princípio da autonomia privada (art. $140 \mathrm{da} \mathrm{CF} / 1988)^{166}$.

Através da opção de venda de ações, uma das partes do acordo de acionistas obriga-se a adquirir as ações da outra dentro de certo prazo ou desde que atendidas determinadas condições ${ }^{167}$. No entanto, embora uma das partes, caso a opção seja exercida, esteja obrigada a comprar as ações da outra, o titular não é obrigado a exercê-la. Trata-se, assim, de um contrato unilateral, na medida que gera obrigações somente para a parte obrigada a comprar. Por isso, uma das disposições que deve constar nesta cláusula é a

165 Ibidem.

166 TEPEDINO, Gustavo. Soluções Práticas de Direito - Empresa e Atividade Negocial. Vol III. p. 475. São Paulo. Revista dos Tribunais. 2012.

167 A opção de venda compulsória de ações pode ser utilizada para diversas finalidades, tais como a) fins de desinvestimento; b) fins de punição por violação do acordo de acionistas; c) o caso de algum dos membros do acordo ser diluído (para menos de 10\%, por exemplo); d) opção de venda a $\mathrm{R} \$ 1,00$ (um real) para saída imediata da companhia (instituições que apoiam empresas via participação acionária e dívida valem-se dessa opção para se desfazer da participação acionária, e preservar o direito de voto na assembleia-geral de credores, caso a empresa entre em recuperação judicial (art. 43, da Lei $n^{\circ} 11.101 / 05$ ); e) opção de venda por decurso de prazo, etc. Cf. BORBA, Rodrigo Rabelo Tavares. Mecanismos contratuais de liquidez nos acordos de acionistas: Da estrutura à função. Dissertação de Mestrado. Programa de pós-graduação em Direito, Universidade do Estado do Rio de Janeiro, Área de concentração: Direito Civil. p. 65. Rio de Janeiro, 2016. 
existência de notificação da parte que detém a opção, manifestando a sua vontade de vender.

Entretanto, em muitos casos, os controladores não detêm recursos financeiros disponíveis para honrar a opção de venda. A fim de se prevenir desse cenário, o fundo de PE/VC como acionista da companhia, deve exigir que o acordo de acionistas preveja a opção de venda compulsória das ações do controlador (drag along), ou ainda, cláusula de buy or sell, etc.

Assim, caso o fundo opte por exercer a cláusula de drag along, ele deverá procurar no mercado eventual interessado em adquirir a totalidade da empresa investida. Ao encontrar o pretendente, o fundo tem direito a alienar a totalidade de ações que estejam em sua titularidade, como também obrigar o controlador a alienar as ações do controle, de tal forma que o pretendente adquira $100 \%$ da participação acionária da companhia ${ }^{168}$.

Na prática, o fundo de $\mathrm{PE} / \mathrm{VC}$ exige que o controlador da companhia investida aceite a inclusão desta cláusula no acordo de acionista ${ }^{169}$, como forma de garantir que, caso a companhia investida não consiga abrir o capital dentro do período vislumbrado pelas partes do investimento de risco, o fundo possa contar com mecanismos eficientes de liquidez de sua participação acionária.

O benefício dessa cláusula é justamente permitir que a companhia seja alienada em sua totalidade, já que dificilmente um terceiro adquiriria uma participação minoritária de uma companhia fechada, sem um acordo de

168 BORBA, Rodrigo Rabelo Tavares. Mecanismos contratuais de liquidez nos acordos de acionistas: Da estrutura à função. Dissertação de Mestrado. Programa de pós-graduação em Direito, Universidade do Estado do Rio de Janeiro, Área de concentração: Direito Civil. p. 59. Rio de Janeiro, 2016.

169 Estudos recentes demonstram que mais de $80 \%$ dos fundos de private equity utilizam o dragalong em seus acordos de acionistas. ___ In. ANDRADE, R.R. Considerações teóricas sobre a potestividade da cláusula de drag along. In: PRADO, V. M., e CARMO, L.U. Estudos Empíricos sobre temas de direito societário. (p. 19-54). São Paulo. Saraiva. 2012. 
acionistas robusto. Isso porque as ações de uma companhia fechada, como já falamos neste trabalho, não têm liquidez. Quem as comprasse ficaria "preso" àquele negócio, sem influência na gestão da companhia, e correria o risco de ter os seus interesses preteridos ${ }^{170}$.

José Virgílio Lopes Enei, em “O capital de risco e o private equity no Brasil: a nova lógica do investimento", ressalta que:

\begin{abstract}
Boas oportunidades de venda podem ser perdidas pelo investidor de venture capital ou private equity interessado na alienação de suas ações porque certos compradores potenciais só têm disposição para adquirir a totalidade das ações da empresa, seja porque desejam maior flexibilidade na sua restruturação pós-venda, porque não desejam minoritários ou porque podem ter restrições comerciais ou de outra natureza com relação aos acionistas remanescentes. Para remover tais obstáculos é comum que o investidor de venture capital ou private equity, possuindo participação majoritária, igualitária $(50 \%)$ ou relevante na sociedade investida, negocie no respectivo acordo de acionistas o direito de, sob certas condições de preço mínimo ou prazo, forçar seus demais acionistas a venderem conjuntamente suas ações (drag along), de maneira a que possa ser alienada a totalidade das ações ao terceiro interessado ${ }^{171}$.
\end{abstract}

Muitas vezes, os acordos de acionistas preveem o direito de preferência em caso do recebimento de uma oferta de compra de ações por uma das partes do acordo. Assim, qualquer dos demais membros do acordo tem o direito de adquirir as ações ofertadas, pelo mesmo preço e nas mesmas condições da oferta recebida.

No caso aqui abordado, em que há a previsão da cláusula de drag along, o veículo investidor de PE/VC, com o intuito de exercer o drag along e vender a totalidade das ações da companhia a um terceiro interessado, deverá respeitar o direito de preferência estabelecido contratualmente, e comunicar aos acionistas originários que recebeu uma oferta de compra, e pretende alienar a totalidade das ações da companhia ao ofertante.

170 BORBA, Rodrigo Rabelo Tavares. Mecanismos contratuais de liquidez nos acordos de acionistas: Da estrutura à função. Dissertação de Mestrado. Programa de pós-graduação em Direito, Universidade do Estado do Rio de Janeiro, Área de concentração: Direito Civil. p. 59. Rio de Janeiro, 2016. 
Respeitado o decurso de tempo previsto na cláusula de direito de preferência, os acionistas originários terão o direito de adquirir, nos mesmos termos e condições previstos na oferta de terceiro, as ações do investidor de $\mathrm{PE} / \mathrm{VC}$.

Ocorre que, a oferta foi elaborada tendo como premissa a compra da totalidade das ações, visto que haveria o exercício do drag along pelo investidor de $\mathrm{PE} / \mathrm{VC}$, o que necessariamente aumenta o valor do montante global da oferta, através do chamado "prêmio de controle". Dessa forma, caso os acionistas fundadores decidam exercer o seu direito de preferência o valor pago proporcionalmente pela participação acionária dos investidores de $\mathrm{PE/VC}$ será necessariamente um valor favorável a estes, visto que o prêmio estará sendo englobado no preço proporcional.

Embora a Lei 6.404/76 ("Lei das S.A.") tenha estabelecido, em seu artigo 254-A, que o montante pago às ações pertencentes aos minoritários corresponderá a $80 \%$ do valor pago pelo adquirente por ação integrante do bloco de controle, este dispositivo se limita à alienação, direta ou indireta, do controle de companhias abertas. Sendo assim, não há previsão legal que restrinja o valor do prêmio de controle englobado às ações dos minoritários de uma companhia fechada, podendo ser um percentual ser maior ou menor àquele previsto em lei. Este valor deverá ser negociado entre as partes, no momento da elaboração da oferta.

A dificuldade do drag along está na sua operacionalização, diante da hipótese de inadimplemento por parte dos empreendedores originais em honrar a obrigação assumida no acordo de acionistas, caso em que o caminho inevitável seria o Poder Judiciário - que, como se sabe, tem uma dinâmica temporal de julgamento incompatível com o mundo dos negócios, 
especialmente no caso dos fundos de $\mathrm{PE} / \mathrm{VC}$, os quais se submetem a rígidos prazos contratuais para promover o desinvestimento ${ }^{172}$.

Mesmo nas hipóteses em que o litígio é julgado por meio da arbitragem, os atos de execução são promovidos pelo Poder Judiciário - resistindo a dificuldade operacional deste mecanismo.

Ao reverso da opção de venda de ações, existe a opção de compra de ações (call option), que consiste no direito de comprar as ações de outra parte do acordo, desde que atendidos certos pressupostos e condições. Rodrigo Tavares Borba, defende em sua tese de mestrado "Mecanismos contratuais de liquidez nos acordos de acionistas: Da estrutura à função" ${ }^{173}$ que enquanto a opção de venda consubstancia um mecanismo de liquidez, a opção de compra consubstancia um mecanismo de tomada do controle ou de expulsão de acionistas minoritários da sociedade investida. Elas funcionam de forma similar, embora estejam dotadas de finalidades diversas.

A opção de venda não se confunde com a promessa de compra e venda, vez que aquela consiste em um contrato unilateral, enquanto esta consiste em um contrato bilateral, ou seja, é considerada um contrato preliminar, mediante o qual uma das partes obriga-se a vender suas ações à outra, que obriga-se, por sua vez, a compra-las, por preço determinado ou determinável ${ }^{174}$.

Outro mecanismo contratual usualmente previsto nos acordos de acionistas é a chamada cláusula de buy or sell, também conhecida como buyout, que confere aos sócios o direito recíproco de comprar ou vender as ações

172 BORBA, Rodrigo Rabelo Tavares. Mecanismos contratuais de liquidez nos acordos de acionistas: Da estrutura à função. Dissertação de Mestrado. Programa de pós-graduação em Direito, Universidade do Estado do Rio de Janeiro, Área de concentração: Direito Civil. p. 60. Rio de Janeiro, 2016.

173 Ibidem

174 EIZIRIK, Nelson. A Lei das S/A Comentada. São Paulo. Quartie Latin do Brasil. p. 713. 2011. 
entre si. José Edwardo Tavares Borba destaca em parecer específico sobre o tema:

Essa cláusula impõe ao sócio, em determinadas situações de impasse, a alternativa, face ao outro, de comprar ou vender as ações da companhia de que participam. Afigura-se solução extremamente inteligente, dotada de elevado conteúdo de equidade, tanto que cabe ao interessado na oferta de compra ou venda (buy or sell) fixar o preço por ação pelo qual comprará todas as ações do outro sócio, ou a ele venderá todas as suas ações. Obtém-se, por esse processo, um desfecho extremamente equitativo, inspirado nos mais elevados ideais de justiça, e, ao mesmo tempo, alcança-se, através da concentração das ações em poder de um só dos grupos desavindos, o retorno da harmonia social ${ }^{175}$.

Essa cláusula é dotada de enorme simplicidade procedimental: em uma sociedade em que há apenas dois sócios, ou blocos de sócios que atuam em conjunto, com participação societária relevante, por exemplo: o sócio "A" com $45 \%$ e o sócio "B" com $54 \%$ do capital social. Uma vez existente uma discórdia entre eles, e desde que preenchidas determinadas condições estipuladas no acordo de acionistas, o sócio "A", insatisfeito, tem o direito de fazer uma oferta de compra das ações de "B". Uma vez recebida a oferta de compra, o sócio "B" tem apenas a seguinte alternativa: ou vende suas ações para "A", ou compra as ações de "A", sempre pelo mesmo preço por ação da oferta original ${ }^{176}$.

Além da celeridade na negociação entre os sócios em litígio, e custo reduzido, por não precisarem contratarem um avaliador/auditor externo, a principal vantagem desta cláusula está na eliminação de divergências sobre preço justo, pois o ofertante tem incentivos econômicos para fazer uma oferta justa, na medida em que pode ser obrigado a vender suas ações pelo mesmo valor por ação, se o ofertado assim o desejar. Ela é uma combinação da cláusula de call option com a de put option. Ao promover a oferta de compra

175 BORBA, José Tavares. Temas de Direito Comercial. Rio de Janeiro. Renovar. p. 8. 2007. 176 BORBA, Rodrigo Rabelo Tavares. Mecanismos contratuais de liquidez nos acordos de acionistas: Da estrutura à função. Dissertação de Mestrado. Programa de pós-graduação em Direito, Universidade do Estado do Rio de Janeiro, Área de concentração: Direito Civil. p. 93. Rio de Janeiro, 2016. 
das ações do outro acionista por determinado valor, já se estará fazendo uma oferta de venda de suas ações, pelo mesmo valor ofertado por ação. ${ }^{177}$ Carlos Augusto Silveira Lobo destaca:

Frequentemente referido como buy-or-sell, é negócio bilateral em que qualquer das partes pode oferecer à outra comprar as ações por esta possuídas, ou vender-lhe suas ações pelo mesmo preço unitário e nas mesmas condições de pagamento aplicáveis tanto à compra quanto à venda. A parte que recebe a oferta fica obrigada, à sua escolha, ou a comprar da ofertante ou a vender-lhe suas ações nos termos da oferta. Essa cláusula é utilizada para resolver impasses ou dissolver associações quando se rompe a affectio societatis, mas tem o efeito de favorecer a parte que tiver mais recursos e maior liquidez para pagar o preço. Segundo as estipulações do acordo, a oferta pode ser feita a qualquer tempo, dentro de prazo, ou ocorrendo condições preestabelecidas $^{178}$.

Essa cláusula se consubstancia tanto um instrumento de controle quanto um instrumento de liquidez, uma vez que ela permite que um minoritário por razões estratégicas, adquira as ações do controlador, tornando-se, ele próprio, o controlador. Da mesma forma, essa cláusula pode ser usada para conferir liquidez às ações minoritárias, vez que as ações do controle são dotadas de muito maior liquidez que as ações minoritárias. Consequentemente, após o acionista minoritário adquirir o controle da sociedade ele terá maiores possibilidades de alienar essas ações ${ }^{179}$.

Embora não exista dúvidas quanto à justiça no momento da fixação do preço, há o risco dessa cláusula ser utilizada de forma disfuncional; ou seja, ela pode ser aplicada não para resolver de forma justa uma disputa normal entre sócios, mas sim como meio para um sócio expropriar ilegitimamente patrimônio do outro ${ }^{180}$. Ocorre assim, o uso disfuncional da cláusula - em

177 Ibidem. p.94.

178 LOBO, Carlos Augusto Silveira. Acordo de Acionistas. In: A. LAMI Filho, e J. B. PEDREIRA, Direito das Companhias. p. 470.Rio de Janeiro: Forense.

179 BORBA, Rodrigo Rabelo Tavares. Mecanismos contratuais de liquidez nos acordos de acionistas: Da estrutura à função. Dissertação de Mestrado. Programa de pós-graduação em Direito, Universidade do Estado do Rio de Janeiro, Área de concentração: Direito Civil. p. 95. Rio de Janeiro, 2016.

180 Rodrigo Rabelo Tavares Borba, destaca em "Mecanismos contratuais de liquidez nos acordos de acionistas: Da estrutura à função" que, embora estruturalmente lícitos, os tribunais não devem tutelar procedimentos que são utilizados de má fé, com finalidade ilícita, pois prejudicam o desenvolvimento nacional, inibindo o desenvolvimento produtivo, e estimulando ainda a má-fé. 
virtude da existência de assimetrias informacional, financeira ou administrativa entre os acionistas da companhia ${ }^{181}$.

Para fins didáticos, imaginem uma sociedade com participação acionária dividida entre dois sócios (49\%/51\%), em que um dos sócios tenha adquirido uma terceira sociedade recentemente, e encontra-se descapitalizado. O outro sócio, tomando conhecimento de tal aquisição, bem como da fragilidade financeira momentânea da sociedade, dispara a cláusula de buy ou sell, oferecendo um preço depreciado por ação. Para que o sócio descapitalizado faça a contraproposta, seria necessário obter investimento bancário oneroso, a proposta torna-se economicamente impossível para ele. Assim, o sócio que dispara a cláusula, teria colocado o outro em um verdadeiro xeque-mate ${ }^{182}$. O sócio ofertante poderia oferecer um preço por ação depreciado na exata medida do custo do financiamento do outro sócio, e o lucro ilícito seria, então, essa exata diferença ${ }^{183}$.

Como forma de evitar a assimetria financeira acima exposta, algumas estratégias de mitigação são utilizadas, como o parcelamento, a carência, a vinculação do fluxo de dividendos da companhia investida, além do

In: BORBA, Rodrigo Rabelo Tavares. Mecanismos contratuais de liquidez nos acordos de acionistas: Da estrutura à função. Dissertação de Mestrado. Programa de pós-graduação em Direito, Universidade do Estado do Rio de Janeiro, Área de concentração: Direito Civil. p. 97. Rio de Janeiro, 2016.

181 TAVERNARD, Mário; CAIXETA, Eduardo. Acordo de Sócios e Conflitos Societários. Apresentação do III Curso de Férias do Grupo de Estudos de Direito Empresaria, Faculdade de Direito da Universidade Federal de Minas Ferais. p. 22 - 32. Disponível em: < http://www.gedemp.com.br/arquivos/3\%20Curso $\% 20 \mathrm{de} \% 20$ Ferias/Acordo $\% 20 \mathrm{de} \% 20$ Socios $\% 20 \mathrm{e}$ \%20Conflitos\%20Societarios\%20-\%20Mario\%20Tavernard\%20e\%20Eduardo\%20Caixeta.pdf >. Acesso em: 04 de maio. 2017.

182 BORBA, Rodrigo Rabelo Tavares. Mecanismos contratuais de liquidez nos acordos de acionistas: Da estrutura à função. Dissertação de Mestrado. Programa de pós-graduação em Direito, Universidade do Estado do Rio de Janeiro, Área de concentração: Direito Civil. p. 94. Rio de Janeiro, 2016.

183 Rodrigo Rabelo Tavares Borba, destaca em "Mecanismos contratuais de liquidez nos acordos de acionistas: Da estrutura à função" que, embora estruturalmente lícitos, os tribunais não devem tutelar procedimentos que são utilizados de má fé, com finalidade ilícita, pois prejudicam o desenvolvimento nacional, inibindo o desenvolvimento produtivo, e estimulando ainda a má-fé.

In: BORBA, Rodrigo Rabelo Tavares. Mecanismos contratuais de liquidez nos acordos de acionistas: Da estrutura à função. Dissertação de Mestrado. Programa de pós-graduação em Direito, Universidade do Estado do Rio de Janeiro, Área de concentração: Direito Civil. p. 97. Rio de Janeiro, 2016. 
pagamento mediante bens distintos de dinheiro. Quando a assimetria é informacional, as seguintes estratégias devem ser utilizadas: (i) a atribuição à parte melhor informada (se conhecida) a qualidade de ofertante; (ii) participação em vendas futuras, em caso de preço superior à cláusula de buy or sell; ou, ainda, (iii) a obrigação de notificar a parte menos informada em caso de eventos materialmente relevantes ${ }^{184}$.

Por fim, a assimetria administrativa ocorre entre as partes com diferentes vocações técnicas. Um exemplo disso é quando a permanência de um acionista não vocacionado para o core business da companhia reduzir o valor do negócio e trazer perdas para ambas as partes. Consequentemente, o acionista não vocacionado pode ser forçado a vender a sua participação, caso tenha dificuldades em obter novo parceiro estratégico ${ }^{185}$.

Dessa forma, quando há assimetrias significativas na companhia, as cláusulas de buy or sell podem, muitas vezes, não atender ao seu objetivo fim: a fixação de um preço justo. Além disso, ainda que os termos da cláusula sejam negociados em condições ideais para a sua adoção, elas podem, com o tempo, ser alteradas, fugindo do seu propósito. Dessa forma, embora a sua inserção em acordos de acionistas não seja incomum, diante dos riscos que lhe são inerentes, seu efetivo acionamento é raro ${ }^{186}$.

Outro mecanismo usualmente utilizado pelos fundos de capital de risco, sobretudo quando os veículos de PE/VC encontram-se na condição de acionista minoritário na companhia investida, é o direito de venda conjunta (tag along). Esta cláusula concede ao acionista o direito de impor aos

184 TAVERNARD, Mário; CAIXETA, Eduardo. Acordo de Sócios e Conflitos Societários. Apresentação do III Curso de Férias do Grupo de Estudos de Direito Empresaria, Faculdade de Direito da Universidade Federal de Minas Ferais. p. 22 - 32. Disponível em: < http://www.gedemp.com.br/arquivos/3\%20Curso $\% 20 \mathrm{de} \% 20$ Ferias/Acordo $\% 20 \mathrm{de} \% 20$ Socios $\% 20 \mathrm{e}$ $\%$ 20Conflitos \%20Societarios\%20-\%20Mario\%20Tavernard\%20e\%20Eduardo\%20Caixeta.pdf >. Acesso em: 04 de maio. 2017.

185 Ibidem.

186 Ibidem. 
acionistas majoritários a venda conjunta de ações caso estes venham a alienar suas próprias ações. ${ }^{187}$

Ademais, por meio dele, o investidor de $\mathrm{PE} / \mathrm{VC}$ tem assegurado outra opção de saída e liquidação de seu investimento, desta vez pelo esforço de negociação da venda com terceiros, mas aderindo à venda negociado pelos seus sócios na companhia investida. Além disso, há o benefício adicional de assegurar ao investidor de $\mathrm{PE} / \mathrm{VC}$ o direito de participar do prêmio de controle calculado na venda.

Outra alternativa, também muito frequente nos acordos de acionistas envolvendo investimentos de capital de risco é a cláusula do direito de preferência na alienação de ações.

No direito societário brasileiro, o direito de preferência é estipulo por lei (art. $1.081 \S 1^{\circ}$, da Lei 10.406/02 e arts. 171 e 109, inciso IV, da Lei das S.A. - este último, dando a esse direito status de direito essencial), e consiste na prerrogativa de adquirir ações da companhia, em qualquer emissão primária de ações. $\mathrm{O}$ direito de preferência pode ser estipulado também contratualmente, hipótese em que opera efeitos apenas entre os contratantes.

É comum a previsão desta última abordagem do direito de preferência nos acordos de acionistas (chamado no direito norte-americano de right of first refusal) - regulando a transferência secundária de ações entre os membros do acordo, vez que o direito de preferência legal já regula a emissão primária de ações. Excepcionalmente, o acordo poderá tratar também da transferência do direito de preferência (art. 171, $\$ 6^{\circ}$, da Lei 6.404/76).

187 ENEI, José Virgílio Lopes. O capital de risco e o Private Equity no Brasil: a nova lógica do investimento. In: ADAMEK, Marcelo Vieira Von (Coord.). Temas de direito societário e empresarial contemporâneos. p. 735. São Paulo: Malheiros, 2011. 
O principal objetivo dos contratantes é impedir que um sócio indesejado ingresse na sociedade. Normalmente, o direito de preferência previsto nos acordos de acionistas obriga o alienante a comunicar aos demais membros do acordo que recebeu uma oferta de compra, e pretende alienar suas ações ao ofertante. Dessa forma, qualquer dos demais membros do acordo tem o direito de adquirir as ações ofertadas, pelo mesmo preço e nas mesmas condições da oferta recebida. $\mathrm{O}$ acordo ainda estipula regras em caso de mais de um membro do acordo decidir exercer o seu direito de preferência.

Até o momento da expedição de notificação de venda, não há aquisição de direitos por nenhuma das partes, e consequentemente não há dívida de qualquer das partes do acordo, pois nenhuma obrigação pode ser exigida de quaisquer dos contratantes. Existe, no entanto, uma expectativa de direito. Estipula-se uma condição suspensiva para a operação de venda se concretizar. Apenas se e quando materializado, pela notificação de venda, o interesse de alienar, é que a eficácia do direito de preferência exsurgirá, passando o ofertante a ser devedor da obrigação de alienar suas ações para os titulares do direito de preferência que decidiram exercê-lo. ${ }^{188}$

Não deve ser confundido o direito de preferência (right of first regusal) com o direito de primeira oferta. No direito de primeira oferta, inverte-se a dinâmica dos fatos: o acionista notifica os demais membros do acordo de que pretende alienar suas ações. Através desta cláusula, os demais acionistas têm o direito de fazer a primeira oferta. Com essa oferta em mãos, o acionista alienante irá ao mercado procurar alguém disposto a cobrir a oferta. O acionista não poderá alienar suas ações para um terceiro por valor menor ou igual ao da oferta recebida pelo membro do acordo. A fim de evitar que a oferta do terceiro represente uma superioridade apenas irrisória, é sensato

188 BORBA, Rodrigo Rabelo Tavares. Mecanismos contratuais de liquidez nos acordos de acionistas: Da estrutura à função. Dissertação de Mestrado. Programa de pós-graduação em Direito, Universidade do Estado do Rio de Janeiro, Área de concentração: Direito Civil. p. 100. Rio de Janeiro, 2016. 
estabelecer uma margem de, por exemplo, 10\%, como condição para que a oferta do terceiro possa prevalecer sobre a primeira oferta. Além disso, o acordo deverá estipular critérios para verificar se essa oferta realizada por membro externo ao acordo concede condições mais vantajosas (como, por exemplo, pagamentos à vista por preço menor). ${ }^{189}$

Como pode-se perceber a cláusula de primeira oferta é mais equitativa e tem o potencial de atrair mais investidores para o "leilão", pois o terceiro não tem o risco de ter a sua proposta coberta por um membro do acordo ${ }^{190}$.

$\mathrm{Na}$ escolha entre uma cláusula ou outra, deve ser levado em consideração se o acionista pretende permanecer na sociedade por muitos anos, caso em que a melhor opção seria a estipulação do clássico direito de preferência. Mas se o acionista pretende se desfazer da ação em curto ou médio prazo, como o caso dos fundos de $\mathrm{PE} / \mathrm{VC}$, o acionista deveria optar pela cláusula de primeira oferta. Rodrigo Tavares Borba explica a problemática em "Mecanismos contratuais de liquidez nos acordos de acionistas: Da estrutura à função":

\begin{abstract}
O processo de decisão pela aquisição de uma participação acionária no mercado de private equity mostra-se normalmente dispendioso. [...]

Imagine-se ter todo esse trabalho para, ao fim do processo, algum membro do acordo de acionistas, ao receber a notificação de que o ofertante pretende vender suas ações para um terceiro nas condições "tais e quais", notificar o alienante de que vai exercer a preferência nas condições "tais e quais". Tal risco é um fator de desestímulo, que afeta a liquidez do investimento, pois muitos potenciais compradores poderão, em virtude deste risco, perder o interesse na aquisição. Ou, então, poderão fazer uma análise sumária, extremamente depreciada, o que acabaria por prejudicar o acionista alienante, e beneficiar os outros membros do acordo de acionistas que poderão exercer o direito de preferência nestas condições depreciadas. ${ }^{191}$
\end{abstract}

189 Ibidem. p.101.

190 Ibidem. p.102.

191 BORBA, Rodrigo Rabelo Tavares. Mecanismos contratuais de liquidez nos acordos de acionistas: Da estrutura à função. Dissertação de Mestrado. Programa de pós-graduação em Direito, Universidade do Estado do Rio de Janeiro, Área de concentração: Direito Civil. p. 101. Rio de Janeiro, 2016. 
Além disso, o acordo de acionistas pode estabelecer a obrigação dos sócios, após determinado prazo sem que a empresa tenha logrado negociar suas ações em bolsa e sem que os acionistas tenham obtido êxito em negociações individuais, realizar o negócio conjunto e coordenado de venda privada das ações - através do engajamento com instituições financeiras e outros especialistas para tanto ${ }^{192}$.

Em outros casos, o investidor de $\mathrm{PE} / \mathrm{VC}$ poderá receber ações preferenciais ou de classe especial que the assegurem o direito, em determinadas circunstâncias ou eventos, de se retirar da sociedade mediante o resgate de ações, como forma de assegurar a liquidação de seu investimento e certa rentabilidade mínima. Um bom exemplo é quando os investidores de $\mathrm{PE} / \mathrm{VC}$ servem como ponte (equity bridge) a um financiamento de longo prazo (em forma de dívida) para o projeto, e a obtenção do financiamento pode servir de autorização para o resgate das suas ações na companhia investida ${ }^{193}$.

Percebe-se que cada um desses mecanismos se encaixa diretamente com a classificação dos métodos de saída/desinvestimento abordados no item anterior. Enquanto que o processo organizado de venda conjunta pode ser utilizado na venda estratégica, o resgate de ações é empregado na venda aos empreendedores fundadores.

Pode-se, portanto, afirmar, como consequência de tudo que foi dito, que, para o investidor institucional, a possibilidade de desinvestimento é tão importante quanto a realização do investimento, e os acordos de acionistas são os instrumentos adequados para assegurar esta possibilidade. Através dos acordos de acionistas, estruturam-se os mecanismos que propiciam ao

192 ENEI, José Virgílio Lopes. O capital de risco e o Private Equity no Brasil: a nova lógica do investimento. In: ADAMEK, Marcelo Vieira Von (Coord.). Temas de direito societário e empresarial contemporâneos. p. 736. São Paulo: Malheiros, 2011.

193 Ibidem. 
acionista exercer a prerrogativa, observadas determinadas condições, de liquidar o seu investimento, desfazendo-se da participação acionária que adquirira $^{194}$.

Rodrigo Tavares Borba destaca em seu trabalho que os vários mecanismos de desinvestimento analisados, em maior ou menor grau, conferem ao investidor a segurança necessária para associar-se a novos empreendimentos, que trazem os riscos que lhes são inerentes, mas que, no seu conjunto, são fundamentais para o crescimento econômico e consequente desenvolvimento social, pressupostos necessários para que se alcance o almejado desenvolvimento nacional. ${ }^{195}$

194 BORBA, Rodrigo Rabelo Tavares. Mecanismos contratuais de liquidez nos acordos de acionistas: Da estrutura à função. Dissertação de Mestrado. Programa de pós-graduação em Direito, Universidade do Estado do Rio de Janeiro, Área de concentração: Direito Civil. p. 131. Rio de Janeiro, 2016.

195 Ibidem. 


\section{CONCLUSÃO}

O incentivo e a preocupação governamental dos diversos países em bem estruturar os investimentos de Private Equity e Venture Capital atestam a importância reconhecida ao segmento de capital de risco para o progresso social e econômico dos países ${ }^{196}$.

Um dos enormes benefícios trazidos pela indústria de Venture Capital e Private Equity é a disponibilização de recursos financeiros que viabilizam a pesquisa e o desenvolvimento de novos produtos e serviços à sociedade uma vez que o financiamento de novas tecnologias, por demandar risco altíssimo, faz com que os métodos tradicionais de financiamento sejam inviáveis para os empreendimentos em fases de desenvolvimento ainda incipientes. Além de onerosos, os tradicionais empréstimos bancários pressupõem uma série de requisitos formais e garantias que muitas vezes se revelam proibitivas aos novos empreendimentos.

Dessa forma, o Venture capital e o Private Equity constituem modelos reconhecidos e difundidos pela prática empresarial, desempenhando papel de grande relevância na implantação de novos empreendimentos e empresas e fomentando a inovação e o desenvolvimento de novas tecnologias. Esses arranjos contribuem não apenas com importante e escasso capital de maior risco, mas também com expertise empresarial e acesso às melhores práticas de gestão ${ }^{197}$.

196 PINTO, Luciane F. Gorgulho. Capital de risco: uma alternativa de financiamento às pequenas $e$ médias empresas de base tecnológica - O caso Contec. Disponível em: < www.bndes.gov.br/SiteBNDES/export/sites/default/bndes_pt/Galerias/Arquivos/conhecimento/rev ista/rev706.pdf > Acesso em: 31 março. 2012.

197 ENEI, José Virgílio Lopes. O capital de risco e o Private Equity no Brasil: a nova lógica do investimento. In: ADAMEK, Marcelo Vieira Von (Coord.). Temas de direito societário e empresarial contemporâneos. p. 737. São Paulo: Malheiros, 2011. 
Dessa forma, sob a lógica de apostar em um empreendimento que pressupõe alto risco, os investidores esperam perspectiva de retorno e rentabilidade maiores que as oferecidas no mercado financeiro tradicional. Para isso, o gestor do veículo de PE/VC leva em consideração, em todas as fases do ciclo de investimento, o setor em que o empreendimento está alocado, o seu respectivo estágio de desenvolvimento, assim como o país em que os empreendimentos encontram-se situados.

No presente trabalho, analisamos a estrutura organizacional dessa modalidade de investimento de capital de risco, os diferentes estágios de desenvolvimento dos negócios alvo desta indústria, as fases do ciclo de investimento do $\mathrm{PE} / \mathrm{VC}$ e as principais características desse tipo de investimento. Em seguida, apresentamos os métodos de desinvestimento, e analisamos os mecanismos contratuais de liquidez que possibilitam que a saída do investimento, uma das fases mais importantes do ciclo de investimento de capital de risco, se concretize conforme planejada pelo gestor no início do ciclo de investimento, e acompanhada durante toda a permanência do veículo de PE/VC no empreendimento.

Ademais, foi demonstrado que, adotando uma estrutura-padrão com a participação de diversos atores especializados, os veículos de Venture Capital e Private Equity inovam em relação a instrumentos tradicionais de investimento acionário, ensejando o desenvolvimento e as negociações de disposições contratuais específicas, a exemplo, aquelas voltadas à liquidação previamente planejada do investimento ${ }^{198}$.

Embora a significativa função social em que o empreendimento de capital de risco é dotado, em razão desses efeitos multiplicadores que geram para a sociedade, o setor enfrenta grande retração nos últimos anos. Se o Estado Brasileiro não conferir uma tutela privilegiada para tais 
investimentos, prejudicados não serão apenas os investidores, mas sim toda a sociedade brasileira. ${ }^{199}$

Ademais, a literatura evidencia que quanto melhor o sistema legal: maior a parcela de investimentos em empresas pequenas e de alta tecnologia; mais rápido o processo de originação e seleção de oportunidades de investimento; maior a probabilidade de coinvestimento entre gestores; menos a probabilidade de que investidores requeiram fluxos de caixa intermediários antes da realização da saída; maior a probabilidade de que saídas ocorram por IPO e menor a probabilidade de saída por meio de revenda da participação ao empreendedor; e, finalmente, maior a taxa de retorno obtida $^{200}$.

Dados do relatório Transactional Track Record (TTR) mostram que os investimentos na indústria de capital de risco no Brasil diminuíram em cerca de $\mathbf{R} \$ 1,5$ bilhão no ano passado, em comparação a 2015. A retração reflete a aversão ao risco do investidor, temeroso diante das incertezas do cenário político-econômico brasileiro. Quem atua nessa indústria, contudo, prefere encarar o número como a representação da "metade cheia do copo". ${ }^{201}$

Para que a indústria volte à boa forma, os gestores esperam contar com a ajuda da Instrução Normativa 578 da CVM, que, conforme destacado neste trabalho, apresentou mudanças significativas para os agentes atuantes neste mercado. Além de ampliar o leque de ativos em que os fundos podem investir

199 BORBA, Rodrigo Rabelo Tavares. Mecanismos contratuais de liquidez nos acordos de acionistas: Da estrutura à função. Dissertação de Mestrado. Programa de pós-graduação em Direito, Universidade do Estado do Rio de Janeiro, Área de concentração: Direito Civil. p. 102. Rio de Janeiro, 2016.

200 NITA. Kleber de Freitas. O Ciclo de Investimento do Capital de Risco no Brasil e as Modalidades de Private Equity e Venture Capital. Trabalho de conclusão de curso. Curso de Ciências Econômicas. Universidade Federal de Santa Catarina, Florianópolis, 2008.

201 DINIZ, Mitchel. Apenas de ano ruim, gestores enxergam horizonte melhor para o investimento em Private Equity. Disponível em: < https://capitalaberto.com.br/temas/gestao-de-recursos/apesarde-ano-ruim-gestores-enxergam-horizonte-melhor-para-o-investimento-em-private-

equity/\#.WRcf0VMrKJA > Acesso em: 15 maio. 2017. 
(como a aplicação de recursos em debêntures simples, em até o limite de 33\% do capital subscrito), a regra autorizou os fundos a investir até $20 \%$ do capital subscrito fora do País. Assim, além de financiar empresas, o FIP passou a ser usado para investimentos em uma série de outros ativos ${ }^{202}$.

No entanto, esse uso indiscriminado do instrumento possibilitou a adoção dos FIPs para finalidades escusas, como apurou-se na Operação Greenfield - deflagrada pela Polícia Federal no ano passado, para investigar irregularidades envolvendo investimentos em FIPs feitos pelas maiores fundações do País: Funcef, Petros, Postalis e Previ. ${ }^{203}$

No entanto, ainda com as incertezas do cenário político-econômico brasileiro, segundo o boletim Focus, os economistas projetam que, no fim de 2017, a Selic pode atingir 8,5\% anuais. Hoje, a taxa básica de juros da economia é de $11,25 \%$ ao ano ${ }^{204}$.

Consequentemente, com a diminuição dos juros, e a perspectiva de continuarem a cair, o mercado de Venture Capital será cada vez mais atrativo - já que uma a rentabilidade dos fundos de renda fixa não continuará sendo tão atrativa como ocorre na conjuntura econômica atual. Assim, estima-se por uma tendência de investimentos em maior quantidade no mercado de Venture Capital e angels.

Conclui-se, portanto, que a perspectiva de desenvolvimento desta atividade de uma forma mais efetiva necessitará de um ambiente macroeconômico mais estável, da redução das taxas de juros para aplicações

202 DINIZ, Mitchel. Apenas de ano ruim, gestores enxergam horizonte melhor para o investimento em Private Equity. Disponível em: < https://capitalaberto.com.br/temas/gestao-de-recursos/apesarde-ano-ruim-gestores-enxergam-horizonte-melhor-para-o-investimento-em-private-

equity/\#.WRcfOVMrKJA > Acesso em: 15 maio. 2017.

203 Ibidem.

204 FOLEGO, Thais. Novas tecnologias e perspectivas de juros baixo aquecem indústria de distribuição. Edição 77. Publicado em 05 de maio de 2017. Disponível em: < https://capitalaberto.com.br/digital/?pageflip_id=s77 >. Acesso em 15 de maio. 2017. 
sem risco, do desenvolvimento do mercado de capitais, envolvendo as bolsas de valores e os novos mercados, bem como da implementação de mecanismos fiscais e regulatórios de estímulo a esta atividade. 


\section{REFERÊNCIAS BIBLIOGRÁFICAS}

1. AGÊNCIA BRASILEIRA DE DESENVOLVIMENTO INDUSTRIAL. A indústria de Private Equity e Venture Capital: $2^{o}$ Censo Brasileiro. Brasília, 2011. p. 61. Disponível em: < http://www.abdi.com.br/Estudo/Private_Equity_e_Venture_Censo.pdf >. Acesso em: 23 abril. 2017.

2. ANDERS, Eduardo Caminati. Private Equity e o controle preventivo exercido pelo Cade. In: ARAGÃO, Leandro Santos; CASTRO, Rodrigo R. Monteiro de. Direito societário: desafios atuais. São Paulo: Quatier Latin, 2009. P. 47.

3. ANDRADE, R.R. Considerações teóricas sobre a potestividade da cláusula de drag along. In: PRADO, V. M., e CARMO, L.U. Estudos Empíricos sobre temas de direito societário. (p. 19-54). São Paulo: Saraiva, 2012.

4. BERNARDINO, Diogo. Fundos de Venture Capital e Private Equity: breve análise sobre sua evolução, características e importância. Revista de Direito Bancário e Mercado de Capitais, São Paulo. v. 61, p.58, jul./set. 2013. Trimestral.

5. BLACK, B.; GILSON, R. Venture Capital and the Structure of Capital Markets: Banks versus Stock Markets. Journal of Financial Economics, n.47, p.243-277, 1998.

6. BORBA, José Tavares. Temas de Direito Comercial. Rio de Janeiro: Renovar, 2007.

7. BORBA, Rodrigo Rabelo Tavares. Mecanismos contratuais de liquidez nos acordos de acionistas: Da estrutura à função. Dissertação de Mestrado. Programa de pós-graduação em Direito, Universidade do Estado do Rio de Janeiro, Área de concentração: Direito Civil. Rio de Janeiro, 2016. 
8. CARVALHO, Antônio Gledson de Carvalho.; RIBEIRO, Leonardo de Lima; FURTADO, Cláudio Vilar. A Indústria de Private Equity e Venture Capital: Primeiro Censo Brasileiro. São Paulo: Saraiva, 2006.

9. CHAMEIN, Sidney. A viabilidade dos projetos alternativos no Brasil. Disponível em: <http://www.investidorinstitucional.com.br/index.php/br/investidores/f undosdepensao/145-revista-investidorinstitucional.html?limit=10\&start=240>. Acesso em: 29 abril. 2017.

10. COMISSÃO DE VALORES MOBILIÁRIOS. Instrução Normativa $n^{o}$ 578, de 03 de agosto de 2016. Disponível em: 〈www.cvm.gov.br>. Acesso em 30 abril.2017.

11. CUMMING, D.; MAcINTOSH, J. A cross-country comparison of full and partial venture capital exits. Journal of Banking \& Finance, Roma, v.27, n.3, p.511-548, Março. 2003.

12. CUMMING, D.; MACINTOSH, J. A Cross-Country Comparison of Full and Partial Venture Capital Exits Strategies, Faculty of Law. Toronto: University of Toronto, 2000, 2002.

13. DINIZ, Mitchel. Apenas de ano ruim, gestores enxergam horizonte melhor para o investimento em Private Equity. Disponível em: < https://capitalaberto.com.br/temas/gestao-de-recursos/apesar-de-anoruim-gestores-enxergam-horizonte-melhor-para-o-investimento-emprivate-equity/\#.WRcf0VMrKJA > Acesso em: 15 maio. 2017.

14. EIZIRICK, Nelson. A Lei das S/A Comentada. São Paulo: Quartie Latin do Brasil, 2011.

15.ENEI, José Virgílio Lopes. O capital de risco e o Private Equity no Brasil: a nova lógica do investimento. In: ADAMEK, Marcelo Vieira Von (Coord.). Temas de Direito Societário e Empresarial Contemporâneos. São Paulo: Malheiros Editores, 2011.

16. ESTADOS UNIDOS. U.S. SMALL BUSINESS ADMINISTRATION. (Org.). Home page. 2017. Disponível em: <https://www.sba.gov/aboutsba> Acesso em: 22 abril 2017. 
17. FOLEGO, Thais. Novas tecnologias e perspectivas de juros baixo aquecem indústria de distribuição. Edição 77. Publicado em 05 de maio de 2017. Disponível em: < https://capitalaberto.com.br/digital/?pageflip_id=s77 >. Acesso em 15 de maio. 2017.

18. FREITAS. Bernardo Vianna; FERRAZ, Adriano Augusto Teixeira; SPRÄNGER, Leon. CVM edita novas regras para fundos de private equity e venture capital: Nova regulamentação afeta principalmente os Fundos de Investimento em Participações (FIPs) e os Fundos Mútuos de Investimento em Empresas Emergentes (FMIEEs). Migalhas. Publicada em 10 out. 2016. Disponível em: < http://www.migalhas.com.br/dePeso/16,MI247029,81042CVM+edita+novas+regras+para+fundos+de+private+equity+e+ventur e+capital > Acesso em 15 maio. 2017.

19. FREITAS. Ricardo de Santos. Natureza Jurídica dos Fundos de Investimento, São Paulo: Quartier Latin, 2006.

20. FUNDAÇÃO GETÚLIO VARGAS. GVcepe. Centro de Estudos em Private Equity. Introdução ao Private Euqity e Venture Capital Paraty Empreendedores. Disponível em: < http://www5.fgv.br/fgvonline/owc/OWCPEVCEAD/index2.htmcpf=9 4700648104\&prod_cd=OCWPEVCECAD_00_O1/2010_1>. Acesso em: 12 dez. 2016.

21. GLADSTONE, D. Venture capital handbook. Englewood Cliffs, NJ: Prentice Hall, 1998. p.215-233.

22. GROH, Alexander; LIECHTENSTEIN, Heinrich; LIESER, Karsten. Iese Business School - University of Navarra - Ernesty \&Yong. The Global venture capital and private equity Country Attractiveness Index. Disponível em: <http://blog.iese.edu/vcpeindex/brazil>. Acesso em: 23 abril. 2017

23. HARMON, Steve. Zero Gavity: Riding Venture Capital from High-Tech Start-Up to Breakout IPO. Priceton, Bloomberg Press, 1999. 
24. INSEAD; PRICEWATERHOUSECOOPERS. Study on private Equity in Brazil.

Disponível

em

<www.insead.edu/facultyresearch/centres/global_private_equity_inicia tive/publications/documents/INSEAD_PwC_Brazil> Acesso em: 23 abril. 2017.

25. Instrução CVM 578 moderniza modo de funcionamento dos FIPs. Publicado em 31 agosto. 2016. Disponível em: < http://www.cnf.org.br/noticia/-/blogs/instrucao-cvm-578-modernizamodo-de-funcionamento-dos-fips >. Acesso em: 15 maio. 2017.

26. Lei Complementar 123, de 14 de dezembro de 2016. Disponível em: < http://www.planalto.gov.br/ccivil_03/leis/LCP/Lcp123.htm > . Acesso em: 15 maio. 2017.

27. LOBO, Carlos Augusto Silveira. Acordo de Acionistas. In: A. LAMI Filho, e J. B. PEDREIRA, Direito das Companhias. p. 470.Rio de Janeiro: Forense.

28. LOBO, Jorge. Fundos de private Equity. In PERIN, Ecio Jr., KALANSKY, Daniel e PEYSER, Luís (Coords.). Direito Empresarial: Aspectos Atuais do Direito Empresarial Brasileiro e Comparado, p. 103-110. São Paulo: Método, 2005.

29. METRICK, Andrew. Venture Capital and the Finance of Innovation. Estados Unidos da América, Wiley, 2007, p. 12 e 13 ("Prefácio" e primeiro capítulo disponíveis em < http://ssrn.com/abstract=929145 >. Acesso em 22/04/2017).

30. METRICK, Andrew; YASUDA,Ayako. Venture Capital \& The Finance of Inovation. Hoboken: John Wiley \& Sons, Inc, 2010, p. 11.

31.NATIONAL VENTURE CAPITAL ASSOCIATION (NVCA). Disponível em: <http://nvca.org/> Acesso em: 22 abril 2017.

32. NESHEIM, John. High -Tech Start Up: the Complete Handbook for Creating Successful New High Tech Companies. Nova York, The Free Pass, 2000; 
33. NETO, Mario Casale. Um estudo sobre a indústria de capital de risco com foco em pequenas e médicas empresas brasileiras. Trabalho de conclusão de curso. Curso de Engenharia de Produção Mecânica. Universidade de São Paulo, São Carlos, 2007.

34. NITA. Kleber de Freitas. O Ciclo de Investimento do Capital de Risco no Brasil e as Modalidades de Private Equity e Venture Capital. Trabalho de conclusão de curso. Curso de Ciências Econômicas. Universidade Federal de Santa Catarina, Florianópolis, 2008.

35.PAVANI, C. O Capital de Risco no Brasil: Conceito, Evolução e Perspectivas. Rio de Janeiro: E-papers, 2003. Apud In: NITA. Kleber de Freitas. O Ciclo de Investimento do Capital de Risco no Brasil e as Modalidades de Private Equity e Venture Capital. Trabalho de conclusão de curso. p. 37. Curso de Ciências Econômicas. Universidade Federal de Santa Catarina, Florianópolis, 2008.

36. PENNA, Paulo Eduardo; REIS. André Provedel. O BOVESPA MAIS como alternativa de saída em investimentos de private equity. Publicado no website da Associação Brasileira de Private Equity e Venture Capital - ABVCAP em setembro de 2013. Disponível em: < http://www.loboeibeas.com.br/archives/3488 >. Acesso em: 15 maio. 2017.

37. PINTO, Luciane F. Gorgulho. Capital de risco: uma alternativa de financiamento às pequenas e médias empresas de base tecnológica - $O$ caso Contec. Disponível em: www.bndes.gov.br/SiteBNDES/export/sites/default/bndes_pt/Galerias/ Arquivos/conhecimento/revista/rev706.pdf > Acesso em: 31 março. 2012.

38. PRICEWATERHOUSECOOPERS (Brasil) (Org.). ISEAD - PwC Study on Private Equity in Brazil: Brazilian Private Equity: A New Direction. 2014. Disponível em: <http://centres.insead.edu/global-private-equityinitiative/researchpublications/documents/INSEAD_PwC_BrazilianPE _NewDirection_2014.pdf.> Acesso em: 23 abril. 2017. 
39. REBELO, Nikolai Sosa. Os Investimentos e a Captação de Recursos por Contratos de Private Equity e Venture Capital. Síntese Direito Empresarial, São Paulo, v. 29, p. 205, nov./dez. 2012. Bimestral.

40. RIBEIRO, Leonardo de Lima. O modelo brasileiro de private equity $e$ venture capital. Dissertação de Mestrado. Programa de pós-graduação em Administração. Universidade de São Paulo, São Paulo, 2005. Apud In: NITA. Kleber de Freitas. O Ciclo de Investimento do Capital de Risco no Brasil e as Modalidades de Private Equity e Venture Capital. Trabalho de conclusão de curso. p. 20. Curso de Ciências Econômicas. Universidade Federal de Santa Catarina, Florianópolis, 2008.

41. RIBEIRO, Leonardo de Lima; ALMEIDA, Martinho Isnard Ribeiro de. Estratégia de saída em capital de risco. R.Adm., São Paulo, v.40, n.1, p.55-67, jan./fev./mar. 2005.

42. RIBEIRO, Leonardo de Lima; ALMEIDA, Martinho Isnard Ribeiro de. Predominância da "venda estratégica" nas estratégias de saída de capital de risco no Brasil: Uma pesquisa empírica. Faculdade de Economia, Administração e Contabilidade da Universidade de São Paulo. Departamento de Administração. Artigo submetido ao VI Semead, agosto 2004.

43. RIBEIRO, Leonardo de Lima; TIRONI, L. F. Ativos Intangíveis: Avaliação e Mensuração no Contexto de Private Equity e Venture Capital. Brasília: IPEA, 2007.

44. RIECHE, Fernando Ceschin; SANTOS, Leonardo Pereira R. dos. Investimentos em pequenas e médias empresas com elevado potencial de crescimento - Critérios de seleção dos capitalistas de risco. Revista do BNDES - Banco Nacional de Desenvolvimento Social e Econômico, vol. 13, n. 26, p. 91. Disponível em: < www.bndes.gov.br/SiteBNDES/bndes/bndes_pt/Institucional/Publicac oes/Consulta_Expressa/Setor/Pequenas_e_Medias > Acesso em: 23 abril.2017 
45. ROCHA. Luciano Velasque; WATANABE. Ricardo Ryohei L. Lei do investidor anjo alinha o Brasil às tendências mundiais. Revista Consultor Jurídico, publicada em 23 de novembro de 2016, 6h22. Disponível em: < http://www.conjur.com.br/2016-nov-23/leiinvestidor-anjo-alinha-brasil-tendencias-mundiais >. Acesso em 12 janeiro. 2017.

46. RUHNKA, J.; FELDMAN, H.; DEAN, T. The "living dead" phenomena in venture capital investments. Journal of Business Venturing, v.7, n.2, p.137-155, Mar. 1992

47.SÁ, Thomas Tosta de. Empreendedorismo e Venture Capital: perspectivas para o Brasil . Disponível em: <http://www.redetec.org.br/publique/media/thomas.pdf>. Acesso em: 22 abril. 2017.

48. SAHLMAN, W.A. The structure and governance of venture capital organizations. Jornal of Financial Economics, Rochester, v.27, n.2, p.473-521, Sept. 1990.

49. SCHAFER, Dorethea. How Important is the Venture Capital Industry? An Assemblent Based on a comparison of the U.S. And the German Financial Systems. p. 9. Disponível em <www.aicgs.org/site/wpcontent/uploads/2011/10/schaefer.pdf> Acesso em: 25 abri. 2017.

50.SCHWIENBACHER, A. An Empirical Analysis of Venture Capital Exits in Europe and in the United States. Berkeley, CA.: University of California, 2002a.

51.SZTAJN, Rachel; AZEVEDO, Paulo Furquim de; ZYLBERSZTAJN, Décio. Economia dos contratos. Apud In: ZYLBERSZTAJN, Décio (orgs.) Direito \& economia. Análise econômica do direito das organizações. Rio de Janeiro: Elsevier, 2005. p. 122-123.

52. TAVERNARD, Mário; CAIXETA, Eduardo. Acordo de Sócios e Conflitos Societários. Apresentação do III Curso de Férias do Grupo de Estudos de Direito Empresaria, Faculdade de Direito da Universidade Federal de Minas Ferais. p. 22 - 32. Disponível em: < 
http://www.gedemp.com.br/arquivos/3\%20Curso\%20de\%20Ferias/Ac ordo $\% 20 \mathrm{de} \% 20$ Socios $\% 20 \mathrm{e} \% 20$ Conflitos $\% 20$ Societarios $\% 20$ $\% 20$ Mario\%20Tavernard\%20e\%20Eduardo\%20Caixeta.pdf >. Acesso em: 04 de maio. 2017.

53. TEPEDINO, Gustavo. Soluções Práticas de Direito - Empresa e Atividade Negocial. Vol III. p. 475. São Paulo. Revista dos Tribunais. 2012.

\section{THE INTERNATIONAL BASIC ECONOMY CORPORATION} (Org.). Historical Notes. 2006. Disponível em: <http://www.capitalflow-analysis.com/investmenttutorial/case_1w.html> Acesso em: 23 abril. 2017

55. WEIDIG, Tom; MATHONET, Pierre-Yves. The Risk Profiles of Private Equity - Private Equity is a risky asset, but private equity investments are not necessarily so. Disponível em: < http://papers.ssrn.com/sol3/papers.cfm?abstract_id=495482 > Acesso em 01. Maio. 2017.

56.XAVIER, Mateus Eckert. Segurança Jurídica nas Operações de Private Equity e Venture Capital. 2015. p.20. Disponível em: <https://repositorio.ufsc.br/handle/123456789/133935>. Acesso em 23 abril. 2017

57. YOKOI, Yuki. Nova regra para FIPs moderniza indústria de private equity. Capital Aberto. Edição 46. Publicado em 02 de setembro de 2016. Disponível em: < https://capitalaberto.com.br/temas/gestao-derecursos/nova-regra-para-fips-moderniza-industria-de-privateequity/\#.WRcfxlMrKJA >. Acesso em: 15 maio. 2017. 
Pontifícia Universidade Católica $_{\text {a }}$

DO RIO DE JANEIRO

$A \cap$

NORMAS PARA ELABORAÇ̃̃O E APRESENTAÇÃO DA MONOGRAFIA

JUR 1919 ou JUR 1916

ANEXO II

A Monografia deve ser entregue até o dia 08 de junho de 2017

A presente Monografia, apresentada pelo(a) aluno(a) BAŔBARA GLENA GOMES DE AGUIAR

poderá ser submetida à exposição e defesa perante a Banca Examinadora designada pelo Departamento de Direito da PUC-Rio.

Rio de Janeiro, O8 de Junho de 2017.

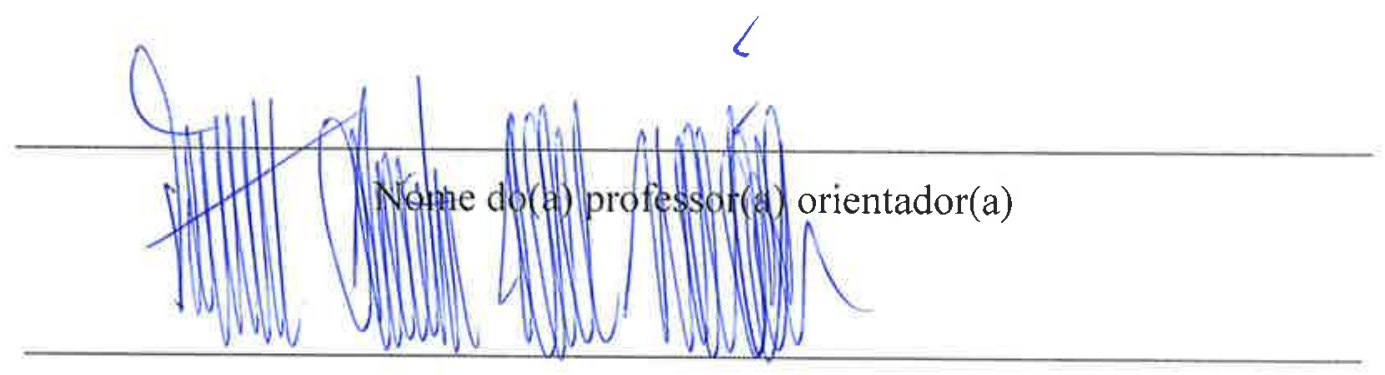

Assinatura do(a) professor(a) orientador(a)

O(A) autor(a) deste trabalho declara para todos os fins de Direito ser este um trabalho inédito e autoriza o Departamento de Direito da PUC-Rio a divulgá-lo, no todo ou em parte, resguardados os direitos autorais conforme legislação vigente.

Rio de Janeiro, O\& de Junk 2017.

Bäbar. Eleno foms despuar

Assinatura do(a) aluno(a) 